\title{
Survey of Degradation Modes of Four Nickel-Chromium-Molybdenum Alloys
}

\author{
G. E. Gdowski
}

March 1991

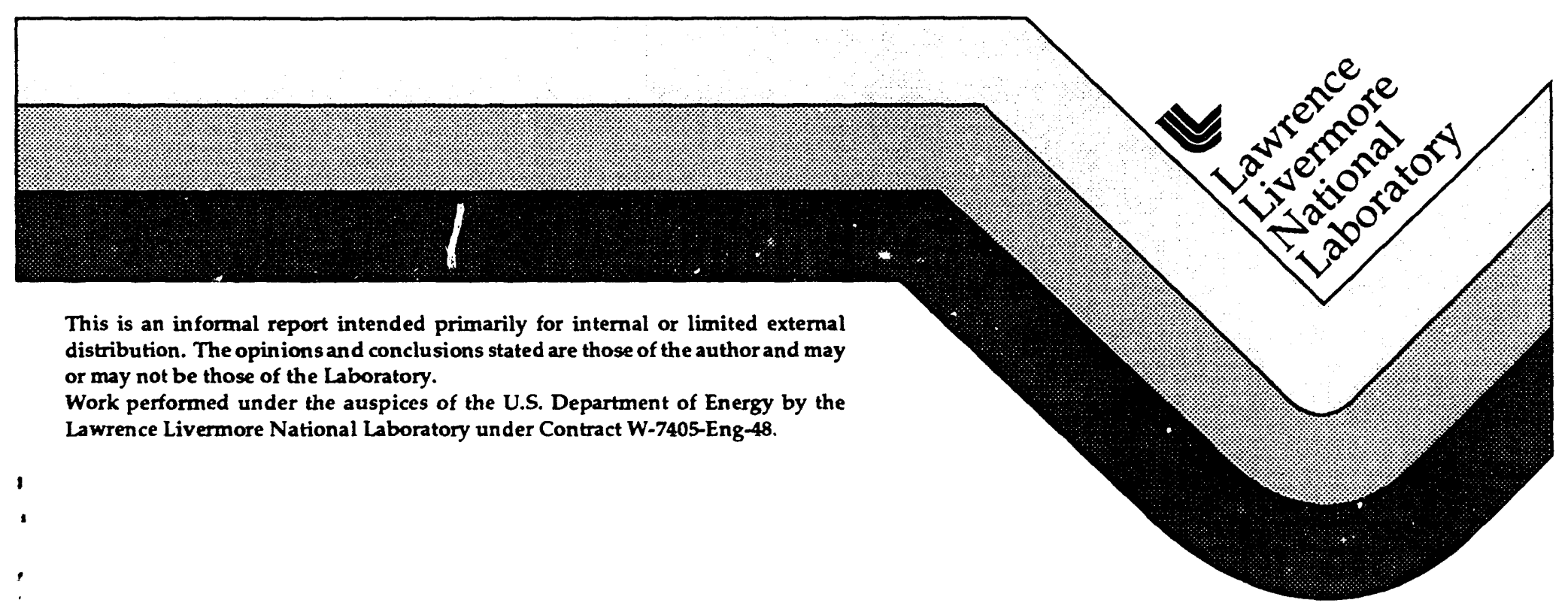




\section{DISCLAIMER}

This document was prepared as an acccount of work sponsored by an agencr of the United States Government. Neither the United States Government nor the University of California nor any of their employees, makes any warranty, express or implied, or assumes any legal liability or responsibility for the accuracy, completeness, or usefulness of any information, apparatus, product, or prccess disclosed, or represents that its use would not in.fringe privately own rights. Reference herein to any specific commercial products, process, or service by trade name, trademark, manufacturer, or otherwise, does not necessarily constitute or imply its endorsement, recommendation, or favoring by the United States Government or the University of California. The views and opinions of authors expressed herein do not necessarily state or reflect those of the United States Government or the University of California, and shall not be used for advertising or product endorsement purposes.

This report has been reproduced directly from the best available copy.

Available to DOE and DOE contractors from the Office of Scientific and Technical Information P.O. Box 62, Oak Ridge, TN 37831

Prices available from (615) 576-8401, FTS 626-8401

Available to the public from the National Technical Information Service

U.S. Department of Commeice 5285 Port Royal Rd. Springfield, VA 22161

Prepared by Yucca Mountain Site Characterization Project (YMP) participants as part of the Civilian Radioactive Waste Management Program. The YMP is managed by the Yucca Mountain Site Characterization Project Office of the U.S. Department of Energy, Las Vegas, Nevada. 
UCRL-ID- -108330

DE92 004469

Survey of Degradation Modes of Four Nickel-Chromium-Molybdenum Alloys

\author{
G. E. Gdowski \\ KMI Energy \\ Livermore, California
}

March 1991 


\section{Contents}

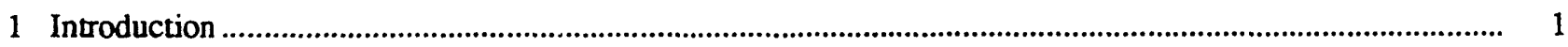

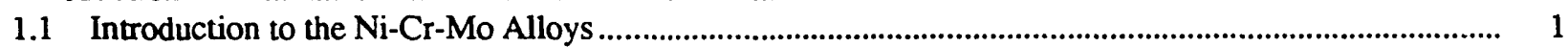

1.2 Overview of the Ni-Cr-Mo Alloys..................................................................................................... 3

1.2 .1 Alloy 825................................................................................................................................. 6

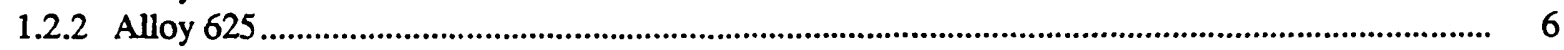

1.2.3 Alloy C-276 ............................................................................................................ 7

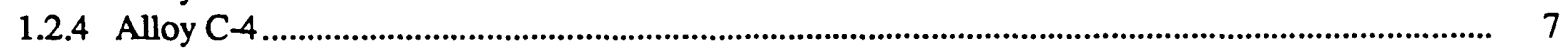

1.2 .5 Alloy C-22 ................................................................................................................................. 7

2 Phase Stability .............................................................................................................................................. 8

2.1 The Ni-Cr-Mo Phase Diagram: The High-Nickel Portion ............................................................................. 8

2.2 Estimated Phase Position of Commercial Alloys .................................................................................. 8

2.3 Aging (Precipitation) Studies.................................................................................................................... 14

2.3.1 Temperatures Less than $600^{\circ} \mathrm{C}$.................................................................................................... 14

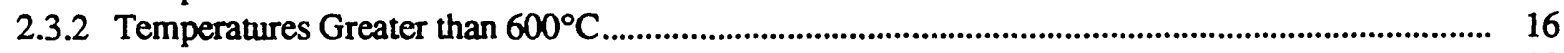

2.4 Summary ............................................................................................................................................... 23

3 Stress Corrosion Cracking and Localized Corrosion in Chloride Environments ............................................... 24

3.1 Introduction to SCC and LC ........................................................................................................... 24

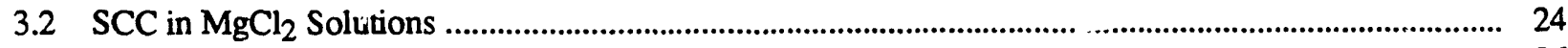

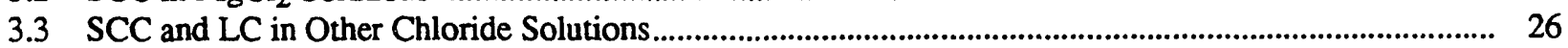

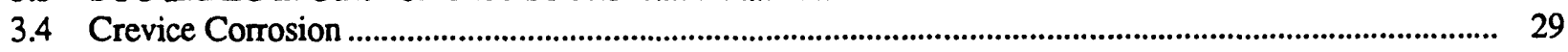

3.5 Effect of Temperature on Pitting .......................................................................................................... 31

3.6 Effect of Cold Work on Pitting .............................................................................................................. 31

3.7 Critical Crevice Corrosion and Pitting Temperatures ................................................................................ 31

3.8 Electrochemical Tests ....................................................................................................................... 32

3.8.1 Anodic Polarization Curves for the Evaluation of Susceptibility to Crevice Corrosion................... 32

3.8.2 Potentiostatic Tests .................................................................................................................... 34

3.9 Effects of Gamma Radiation on SCC .............................................................................................. 34

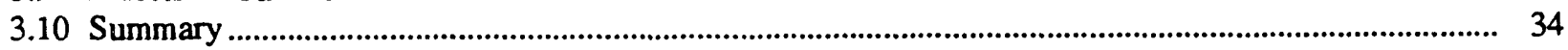

4 Corrosion in Marine Atmospheres and Brines ……....................................................................................... 35

4.1 Marine Atmospheric Corrosion ............................................................................................................ 36

4.2 Marine Immersion Corrosion .................................................................................................................. 37

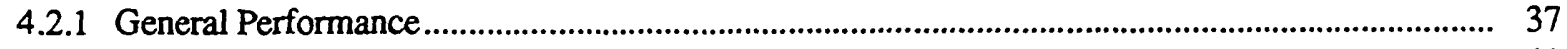

4.2.2 Crevice Corrosion ............................................................................................................... 41

4.2.3 Corrosion Resistance at Elevated Temperatures.............................................................................. 41

4.3 Deep-Seawater Corrosion ................................................................................................................... 42

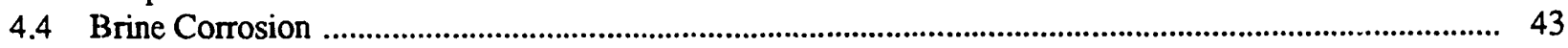

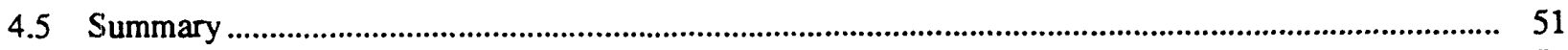

5 SCC in Hydrogen Environments .............................................................................................................

5.1 Immunity of Uncoupled Specimens to HE ........................................................................................ 52

5.2 Effect of Alloy Composition .......................................................................................................... 52

5.3 Effect of Stressing Direction .............................................................................................................

5.4 Effect of Cold Work ............................................................................................................................. 54

5.5 Effect of Aging .............................................................................................................................. 54

5.6 Effect of Hydrogen Charging Current and Electolytes on HE ........................................................... 56

5.7 Effect of Temperature .................................................................................................................. 57

5.8 Effect of Solution Composition ………........................................................................................ 58

5.9 Effect of Stress Level .............................................................................................................. 58

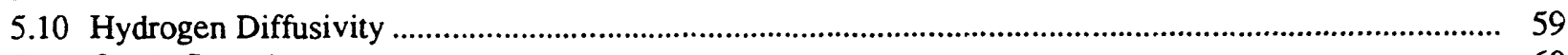

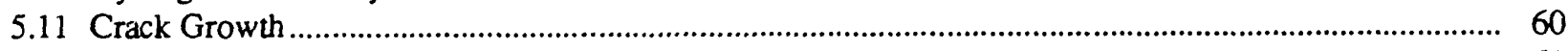

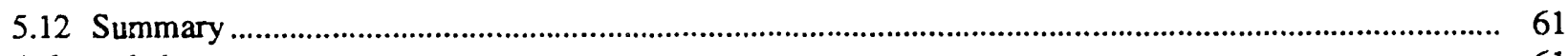

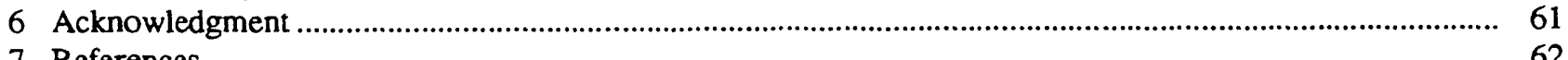

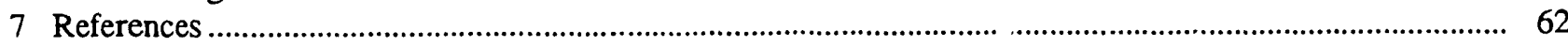




\section{Acronyms}

$\begin{array}{ll}\text { AES } & \text { Auger electron spectroscopy } \\ \text { ASTM } & \text { American Society for Testing and Materials } \\ \text { CD } & \text { conceptual design } \\ \text { CR } & \text { cold-rolled } \\ \text { DTA } & \text { differential thermal analysis } \\ \text { fcC } & \text { face-centered cubic } \\ \text { HE } & \text { hydrogen embrittlement } \\ \text { IGSCC } & \text { intergranular stress corrosion cracking } \\ \text { LC } & \text { localized corrosion } \\ \text { mpy } & \text { mils per year } \\ \text { NACE } & \text { National Association of Corrosion Engineers } \\ \text { SCC } & \text { stress corrosion cracking } \\ \text { SCP } & \text { Site Characterization Plan } \\ \text { SRO } & \text { short-range ordering } \\ \text { SS } & \text { stainless steel } \\ \text { TCP } & \text { topologically close-packed } \\ \text { TGSCC } & \text { transgranular stress corrosion cracking } \\ \text { TTF } & \text { time to failure } \\ \text { TTT } & \text { time-temperature transformation } \\ \text { YMP } & \text { Yucca Mountain Site Characterization Project }\end{array}$




\title{
Survey of Degradation Modes of Four Nickel-Chromium-Molybdenum Alloys
}

\begin{abstract}
This report examines the degradation modes of four Ni-Cr-Mo alloys under conditions relevant to the Yucca Mountain Site Characterization Project (YMP). The materials considered are Alloys C-276, C-4, C-22, and 625 because they have desirable characteristics for the conceptual design $(\mathrm{CD})$ of the high-level radioactive-waste containers presented in the YMP Site Characterization Plan (SCP).

The types of degradation covered in this report are general corrosion; localized corrosion, including pitting and crevice corrosion; stress corrosion cracking in chloride environments; hydrogen embrittlement ( $\mathrm{HE}$ ); and undesirable phase transformations due to a lack of phase stability. Topics not specifically addressed are welding concerns and microbiological corrosion.

The four Ni-Cr-Mo alloys have excellent corrosion resistance in chloride environments such as seawater as well as in more aggressive environments. They have significantly better corrosion resistance than the six materials considered for the $\mathrm{CD}$ waste container in the YMP SCP. (Those six materials are Types $304 \mathrm{~L}$ and $316 \mathrm{~L}$ stainless steels, Alloy 825, unalloyed copper, $\mathrm{Cu}(70)-$ $\mathrm{Ni}(30)$, and $7 \%$ aluminum bronze.) In seawater, the Ni-Cr-Mo alloys have negligible general corrosion rates and show little evidence of localized corrosion. The four base materials of these alloys are expected to have nearly indistinguishable corrosion resistance in the YMP environments.

The strength requirements of the SCP-CD waste container are met by these materials in the annealed condition; in this condition, they are highly resistant to HE. Historically, HE has been noted when these materials have been strengthened (cold-worked) and used in sour gas $\left(\mathrm{H}_{2} \mathrm{~S}\right.$ and $\mathrm{CO}_{2}$ ) well service - conditions that are not expected for the YMP.

Metallurgical phase stability may be a concern under conditions favoring (1) the formation of intermetallics and carbides, and (2) microstructural ordering. These phenomena can degrade mechanical properties and corrosion resistance. Properly treated base materials are not expected to be susceptible because of kinetic limitations at the service temperatures. Insufficiently treated heat-affected zones of welds, however, may be susceptible to the formation of deleterious microstructures. A comparison of alloys shows that Alloy C-4 is the most resistant to microstructural changes.

Alloy C-4 is judged to have the best overall properties of the alloys considered, primarily because of its superior metallurgical stability. All of the materials have excellent corrosion resistance.
\end{abstract}

\section{Introduction}

\subsection{Introduction to $\mathrm{Ni}-\mathrm{Cr}-\mathrm{Mo}$ Alloys}

The Yucca Mountain Site Characterization Project has the task of selecting a material from which to fabricate high-level nuclear-waste containers for the potential repository at Yucca Mountain, Nevada (DOE 1988).
Several high-nickel alloys have properties that are desirable for this purpose. These materials are in the $\mathrm{Ni}-\mathrm{Cr}$ Mo group of alloys and include Alloys 625, C-276, C-22, and $C-4$. (Table 1 lists the common names of the materials mentioned in this report as well as their Unified Numbering System (UNS) designations and other names.) 
Table 1. Names of alloys referred to in this report.

\begin{tabular}{|c|c|c|}
\hline Common alloy name & UNS designation & Other names \\
\hline Type 304 stainless steel & $\mathbf{S 3 0 4 0 0}$ & AISI 304 \\
\hline Type 304L stainless steel & S30403 & AISI 304r \\
\hline Type 316 stainless steel & S31600 & AISI 3\%6 \\
\hline Type 316L stainless steel & S31603 & AISI 316L \\
\hline Type 317 stainless steel & S31700 & AESI 317 \\
\hline Type 317LM stainless steel & S31725 & 317LM \\
\hline Alloy 800 & N08800 & Incoloy ${ }^{2} 800$ \\
\hline Alloy 825 & N08825 & Incoloy 825, Ni-O-Nel \\
\hline Alloy $904 \mathrm{~L}$ & N08904 & $904 \mathrm{~L}$ \\
\hline Alloy 625 & N06625 & Inconel $^{\mathrm{b}} 6.25$ \\
\hline Alloy C & N10002 & Hastelloy ${ }^{\mathbf{c}} \mathbf{C}$ \\
\hline Alloy C-276 & N10276 & Hastelloy C-276 \\
\hline Alloy C-22d & N06022 & Hastelloy C-22 \\
\hline Alloy C-4 & N06455 & Hastelloy C-4 \\
\hline Alloy G & N06007 & Hastelloy G \\
\hline Alloy G-3 & N06985 & Hastelloy G-3 \\
\hline Alloy G-30e & N06030 & Hastelloy G-30 \\
\hline Alloy $\mathbf{X}$ & N06002 & Hastelloy X \\
\hline Alloy $20 \mathrm{Cb}-3$ & N08020 & Carpenter $20 \mathrm{Cb}-3$ \\
\hline Alloy 20-Mod & N08320 & Haynes\& No. 20-Mod \\
\hline Alloy 600 & N06600 & Inconel 600 \\
\hline Alloy 400 & N04400 & Monel $^{\text {h }} 400$ \\
\hline Alloy MP35N & R30035 & Mu tiphase ${ }^{i}$ MP35N \\
\hline Alloy Allcorr & N06110 & Allcurr \\
\hline Alloy $R-41$ & N07041 & Rene $41^{j}$ \\
\hline Alloy 255 & S32550 & Ferraliumk 255 \\
\hline
\end{tabular}

a Incoloy is a registered trademark of International Nickel Corporation, Inc.

b Inconel is a registered trademark of International Nickel Corporation, Inc.

c Hastelloy is a registered trademark of Haynes International, Inc.

d C.22 is a trademark of Haynes International, Inc.

e G-30 is a registered trademark of Haynes International, Inc.

f Carpenter is a registered trademark of Carpenter Technology Corporation.

B Haynes is a registered trademark of Haynes International, Inc.

h Monel is a registered trademark of International Nickel Corporation, Inc.

i Multiphase is a registered trademark of Standard Press Steel Company

j Rene 41 is a registered trademark of Allvac Metals Company (a Teledyne Company)

$k$ Ferralium is a registered trademark of Langley Alloys, Ltd.

The Ni-Cr Mo alloys have a demonstrated utility in several environments, including oxidizing and reducing chloride environments. This report discusses several properties of these materials: their resistance to general corrosion, localized corrosion (LC), and hydrogen embrittlement (HE), and their phase stability. Welding concerns and microbiological corrosion are not discussed. 
Table 2. Effects of alloying elements on the corrosion resistance of highly alloyed materials (Kolts et al. 1986).

\begin{tabular}{llll}
\hline $\begin{array}{c}\text { Alloying } \\
\text { element }\end{array}$ & $\begin{array}{c}\text { Nonoxidizing } \\
\text { acid }\end{array}$ & $\begin{array}{c}\text { Oxidizing } \\
\text { acid }\end{array}$ & Alkali \\
\hline Iron & Bad & Good & Acceptable \\
Nickel & Acceptable & Variable & Excellent \\
Chromium & Variable & Excellent & Acceptable \\
Molybdenum & Excellent & Bad & Bad \\
Tungsten & Good & Variable & Acceptable \\
\hline
\end{tabular}

The Ni-Cr-Mo alloys have useful resistance to uniform corrosion and localized forms of corrosion such as pitting, crevice corrosion, and stress corrosion cracking (SCC). Table 2 shows the effect of alloying additions on resistance to corrosion in different environments. The chromium additions are primarily responsible for the resistance to corrosion in oxidizing environments, while the molybdenum additions improve the resistance to corrosion in reducing environments. The high nickel contents are responsible for the good resistance to SCC in chloride environments. The chromium contents of the alloys considered range from 14 to $23 \mathrm{wt} \%$, the molybdenum contents range from 8 to $17 \mathrm{wt} \%$, and the nickel contents are greater than $50 \mathrm{wt} \%$. Some of the alloys contain additional elements such as tungsten, columbium, or cobalt, both for improved high-temperature strength and for additional resistance to corrosion in some media.

The $\mathrm{Ni}-\mathrm{Cr}$-Mo alloys show unusual resistance to a wide variety of corrosives. Those with a high chromium content have the best resistance to strongly oxidizing solutions such as nitric acid and to hightemperature oxidation. Those with a high molybdenum content have the best resistance to reducing environments such as straight sulfuric and hydrochloric acid and to pitting attack in chloride environments. Those alloys with both high chromium and high molybdenum contents have good resistance in mixed oxidizing and reducing acids such as nitric-sulfuric and nitrichydrofluoric acids. In addition, they have good resistance to (1) some acid mixtures containing oxidizing salts such as ferric, cupric, and chromic salts, and (2) corrosion and pitting attack by oxidizing chloride solutions such as solutions of ferric chloride, cupric chloride, wet chlorine, and hypochlorites.

Table 3 lists the compositions of some of the $\mathrm{Ni}$ Cr-Mo alloys (SAE 1986). For purposes of comparison with the austenitic candidate materials originally considered for the metallic barrier at Yucca Mountain
(Farmer et al. 1988), the table also gives the compositions of Types 304L and 316L stainless steels and Alloy 825. It is important to note the higher molybdenum and nickel contents of the nickel alloys as compared with the stainless steels and Alloy 825. Table 4 lists the compositions of other alloys referred to in this report.

Table 5 lists the typical mechanical properties of the annealed Ni-Cr-Mo alloys, Types 304L and 316L stainless steels, and Alloy 825. The Ni-Cr-Mo alloys listed are medium-strength alloys whose strengths are comparable to or better than those of the austenitic stainless steels.

The Ni-Cr-Mo alloys considered are all austenitic; however, they can be subject to precipitation of intermetallic and carbide phases when aged. This precipitation of secondary phases usually promotes corrosion attack. The problem is rarely encountered in practice because the alloys are supplied in the annealed condition, and the usual service temperatures rarely approach the level required for sensitization (Hodge 1985). However, the high-level radioactive-waste containers will have an unprecedented service lifetime $(300-1000 \mathrm{yr})$ at moderate temperatures $\left(50-250^{\circ} \mathrm{C}\right)$, and, therefore, the phase stability of the alloys needs to be investigated.

Carbide precipitation has been and is of particular concern for susceptibility to corrosion. Carbide precipitation can be minimized by lowering the carbon content, and modern metallurgical techniques can produce nickel alloys with a lower carbon content than previously obtainable (Hodge 1985). In high-nickel (>50\%) alloys, carbon solubility is low-a factor of 10 lower than in austenitic stainless steels-and the carbide formed is predominantly $\mathrm{M}_{6} \mathrm{C}$. In austenitic stainless steels, $\mathrm{M}_{23} \mathrm{C}_{6}$ is predominantly formed. It was previously difficult to produce a low-carbon grade of highnickel alloys because of the state of the art in melting. To circumvent this problem, many alloys were developed by adding carbide stabilizers to tie up the carbon, with varying degrees of success. Melting techniques for nickel alloys have recently been improved, however. The transfer of alloys from air-induction or vacuuminduction melting to air-arc plus argon-oxygen decarburization has provided a means of producing nickel alloys that are comparable to the low-carbon $(\mathrm{L})$ grades of stainless steels.

\subsection{Overview of the Ni-Cr-Mo Alloys}

This section is an introduction to the corrosion resistance and the typical uses of the Ni-Cr-Mo alloys. The overviews of the alloys are primarily taken from a review article written in 1985 by Hodge entitled 

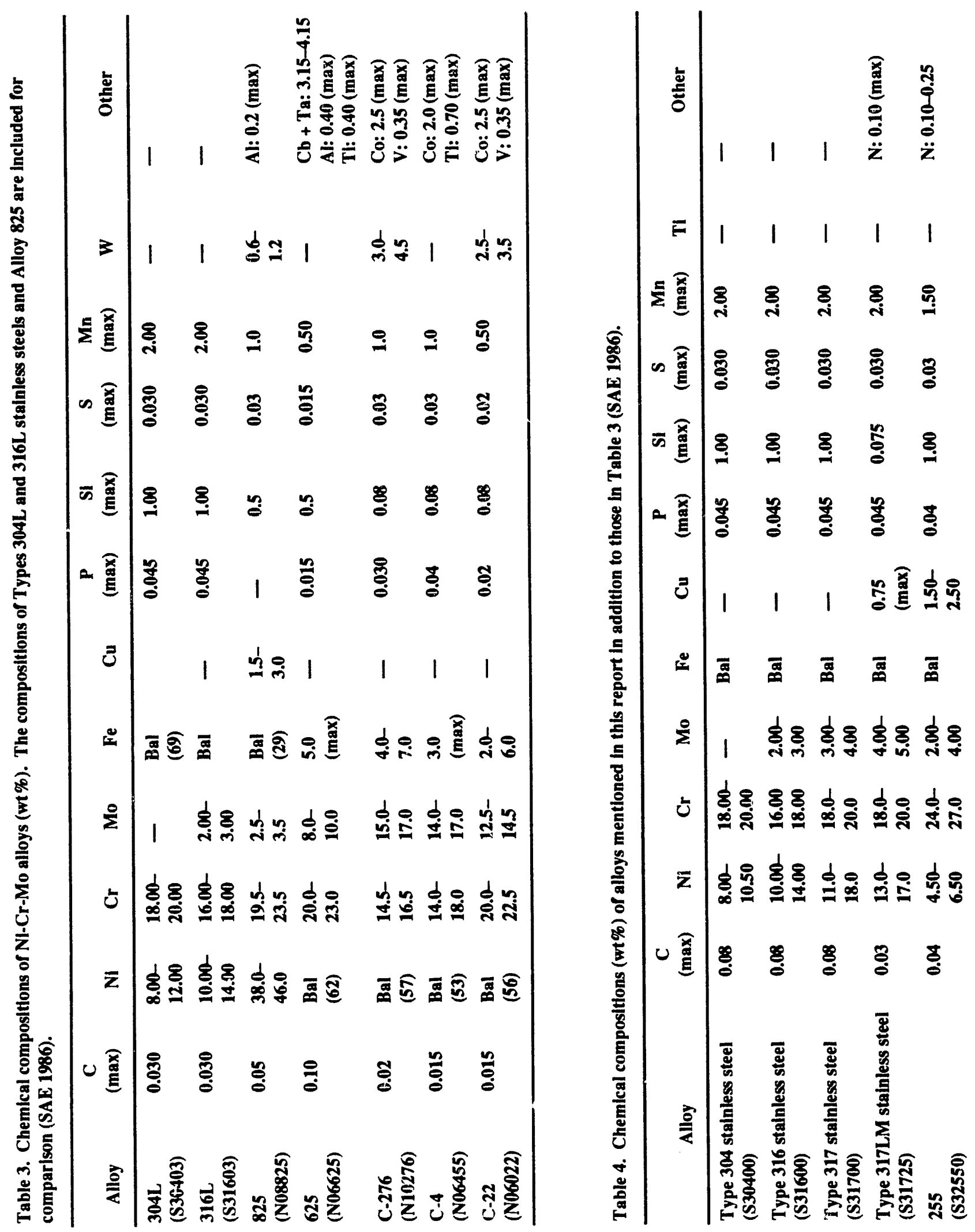


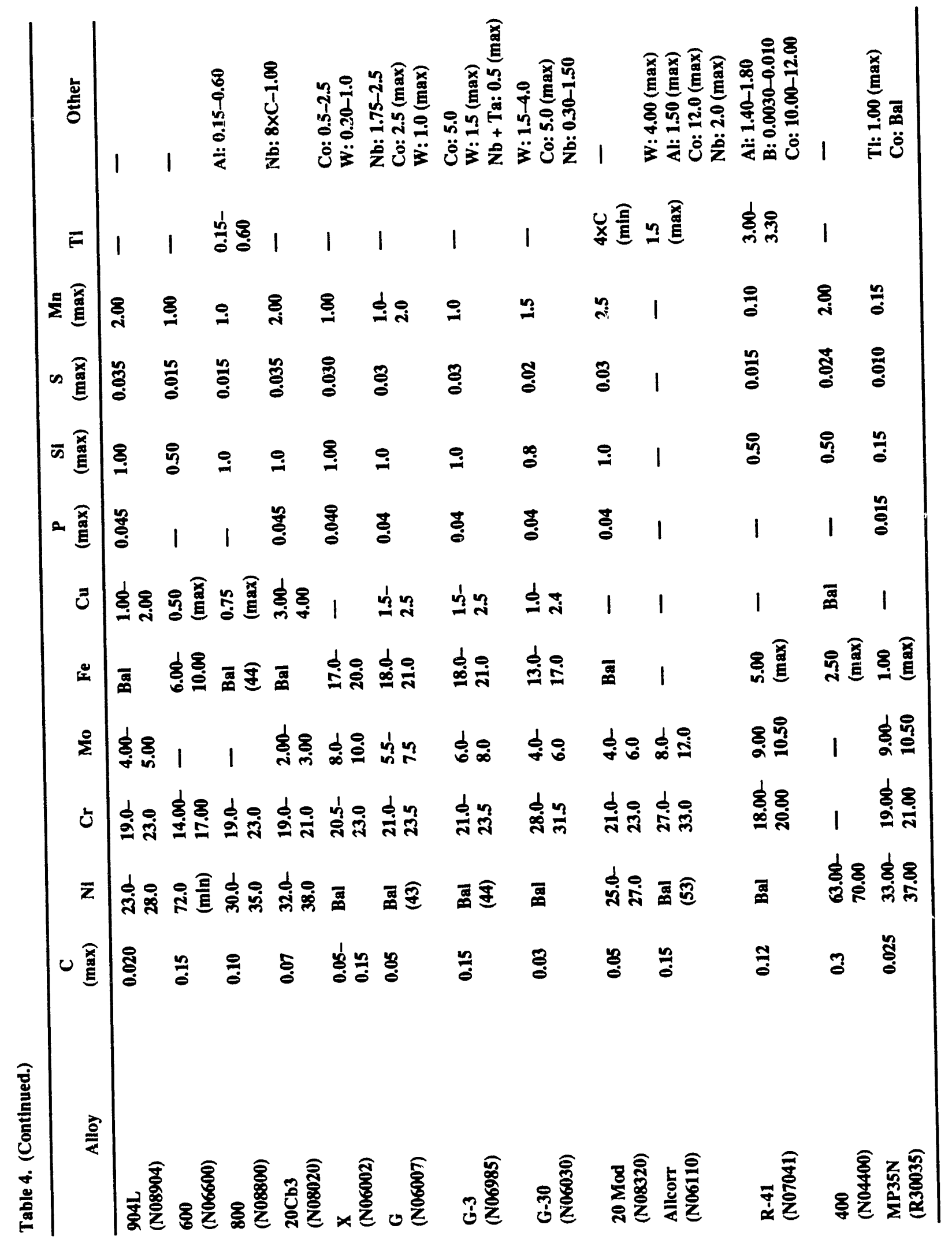


Table 5. Typical mechanical properties of annealed materials.

\begin{tabular}{lccc}
\hline & $\begin{array}{c}\text { Yield } \\
\text { stress } \\
\text { ksi } \\
\text { Alloy }\end{array}$ & $\begin{array}{c}\text { Ultimate } \\
\text { terisile } \\
\text { strength ksi } \\
\text { (MPa) }\end{array}$ & $\begin{array}{c}\text { Elongation } \\
(\%)\end{array}$ \\
\hline $\begin{array}{l}\text { Type 304 } \\
\text { stainless steela }\end{array}$ & $33(227)$ & $89(620)$ & 71 \\
$\begin{array}{l}\text { Type 316 } \\
\text { stainless steel }\end{array}$ & $34(234)$ & $85(586)$ & 61 \\
825 $^{\text {b }}$ & $50(345)$ & $95(655)$ & 40 \\
625 $^{\text {b }}$ & $70(483)$ & $135(931)$ & 42 \\
C-276 & $42(290)$ & $100(689)$ & 56 \\
C-4b & $53(365)$ & $113(779)$ & 55 \\
C-22c & $59(407)$ & $116(800)$ & 57 \\
\hline
\end{tabular}

a Peckner (1977)

b Hodge (1985).

c Haynes (1988).

"Nickel and High Nickel Alloys." Additional information on Alloy 625 was taken from an article by Friend (1980). Information on Alloy C-22 was taken from a Haynes International, Inc., product bulletin (Haynes 1988). Alloy 825 is included in this section because it is considered a high-nickel alloy.

\subsubsection{Alloy 825}

Alloy 825 contains about $22 \% \mathrm{Cr}, 30 \% \mathrm{Fe}, 42 \%$ $\mathrm{Ni}, 1.8 \% \mathrm{Cu}, 3.0 \% \mathrm{Mo}$, and $0.90 \% \mathrm{Ti}$. The combination of Ni-Cr-Mo-Fe with $1.8 \%$ Cu provides good resistance in pure sulfuric acid. On the basis of test results and service experience, the alloy should have useful resistance in solutions of up to $40 \mathrm{wt} \%$ sulfuric acid at boiling temperatures and in solutions of all concentrations at a maximum temperature of $66^{\circ} \mathrm{C}$. In dilute solutions, the presence of cupric or ferric oxidizing salts actually lowers the observed corrosion rates. Alloy 825 has only limited use in hydrochloric or hydrofluoric acid, but it has good resistance to phosphoric acid and has bein used in some commercial acid applications.

The alloy is not fully resistant to SCC when tested in boiling magnesium chloride solution, but it has good resistance in neutral chloride environments. For this reason it is sometimes substituted for the 300-series stainless steels when LC is a problem. One present application is in pollution control equipment. The alloy resists SCC; however, the molybdenum content is the same as that of Type 317 stainless steel. The increased nickel content gives Alloy 825 better pitting resistance, but it is not as resistant as a number of other commercially available alloys.

Typical phosphoric acid applications of Alloy 825 include pickling tank heaters, pickling hooks and equipment, chemical process equipment, spent nuclear fuel element recovery, propeller shafts, and tank trucks.

\subsubsection{Alloy 625}

This alloy has been used extensively in sheet form in high-temperature gas-turbine applications. Because of its combination of alloying elements such as chromium, molybdenum, carbon, and columbium plus tantalum, the alloy retains its strength and oxidation resistance at elevated temperatures. Typical applications include ducting systems, thrust reverser assemblies, and afterbumers. Use of the alloy has been considered in high-temperature gas-cooled reactors; however, after long aging times in the temperature range of 590 to $760^{\circ} \mathrm{C}$, the room-temperature ductility is significantly reduced.

Resistance to aqueous solutions is good in a variety of applications, including organic acid, sulfuric acid, and hydrochloric acid at temperatures below $65^{\circ} \mathrm{C}$. The alloy has satisfactory resistance to hydrofluoric acid and has been used as a liner in a hydrofluoric acid generator that reacts sulfuric acid with fluorspar. Although nickel-base alloys are not generally used in nitric acid service, Alloy 625 is resistant to mixtures of nitrichydrofluoric acid, in which stainless steels lose their resistance.

Alloy 625 has excellent resistance to phosphoric acid solutions. Actual field operating information has shown this alloy to have excellent resistance to commercial grades of acid that contain fluorides, sulfates, and chlorides in the production of superphosphoric acid $\left(72 \% \mathrm{P}_{2} \mathrm{O}_{5}\right)$.

The columbium and tantalum stabilization (3.65\%) makes the alloy suitable for corrosion services in the aswelded condition. The high nickel content provides good resistance to chloride SCC. Alloy 625 has a relatively high molybdenum content (9\%), and field-testing data place its performance somewhere near Alloy C-276 in resistance to pitting and crevice corrosion.

Recently, Alloy 625 has been utilized in new pollution control applications including reheaters for $\mathrm{SO}_{2}$ scrubbing systems on coal-fired power plants, and bottoms of electrostatic precipitators that are flushed with seawater. In one installation, the interior stack was lined to provide resistance to the wet sulfurcontaining gases.

Additional general information on Alloy 625 is given by Friend (1980), who states: 
The commercial wrought Alloy $625(61 \mathrm{Ni}-22 \mathrm{Cr}$ $9 \mathrm{Mo}-3 \mathrm{Fe}-3.65 \mathrm{Cb}+\mathrm{Ta}$ ) has higher chromium and lower molybdenum contents than the $\mathrm{Ni}-16 \mathrm{Cr}$-16Mo alloys. The higher chromium content provides increased resistance to some strongly oxidizing environments such as nitric acid and some of its mixtures and to high-temperature oxidation up to $980^{\circ} \mathrm{C}$. The lower molybdenum content causes decreased resistance to hydrochloric acid and to pitting attack in hot chloride solution such as ferric and cupric chlorides. The matrix stiffening effect provided by the additions of columbium and molybdenum to the nickel-chromium matrix results in improvement in tensile, creep, and fatigue properties at temperatures up to at least $650^{\circ} \mathrm{C}$. As a resulth a number of the applications of this alloy are in fields where these mechanical properties, as well as corrosion resistance, are required. In the aerospace field the alloy is used for such applications as aircraft ducting systems, engine exhaust systems, thrust reverse systems, fuel and hydraulic line tubing, bellows, and turbine shroud rings. It also is suitable for such uses as combustion system transition lines, turbine seals, compressor vanes, and thrust chamber tubing for rocket motors.

\subsubsection{Alloy C-276}

Alloy C-276 is a version of Alloy $C$ that is low in carbon (0.01\% maximum) and silicon (0.08\% maximum). Alloy C-276 was developed to overcome the corrosion problems associated with the welding of Alloy $C$. In the as-welded condition, Alloy $C$ was susceptible to serious intergranular corrosion attack in many oxidizing and chloride-containing environments. The low carbon and silicon content of Alloy C-276 prevents precipitation of continuous grain boundary precipitates in the heat-affected zone of the weld. Thus Alloy C-276 can be used in most applications in the as-welded condition without suffering severe intergranular attack.

This alloy possesses good resistance in both oxidizing and reducing media, including those contaminated with halogen ions. The resistance of Alloy C-276 to pitting and crevice corrosion makes it an excellent choice when dealing with acid chloride salts, whether in the process or in merely hardling hot seawater in heat exchangers.

Alloy C-276 is a good compromise material to those alloys that have excellent resistance to either strongly oxidizing or reducing media in that it has good corrosion resistance in several media. For example, in sulfuric acid coolers handling $98 \%$ acid from the absorption tower, Alloy C-276 is not the optimum alloy for the process-side corrosion, but it is excellent for the water-side corrosion and allows the use of brackish water or seawater.

Alloy C-276 has been used in the pollution control industry, primarily in scrubbing systems. It has been performing satisfactorily for years in a particularly aggressive environment of wet/dry conditions. It is also a good material for the construction of scrubbers in which problems of localized attack have occurred with other materials because of $\mathrm{pH}$, temperature, or chloride content.

\subsubsection{Alloy $\mathrm{C}-4$}

A new $\mathrm{Ni}-\mathrm{Cr}-\mathrm{Mo}$ alloy known as Alloy $\mathrm{C}-4$ has been developed that has improved stability with regard to precipitation of both carbides and intermetallic phases. The control of these secondary phases results in excellent high-temperature stability - such that the corrosion resistance and mechanical properties in the thermally aged condition are similar to those in the annealed condition.

Within the broad scope of chemical processing, there are numerous examples in which oxidizing and reducing conditions can cause serious intergranular corrosion of a sensitized microstructure. A sensitized structure can result from several sources, such as (1) improper annealing, (2) welding , (3) thermomechanical processing, such as hot forming or rolling operations, (4) stress relief or normalizing treatments required for carbon steel backing of clad materials, and (5) operation of process equipment in the sensitizing range. Alloy $\mathrm{C}-4$ represents a significant improvement over the common austenitic alloys because it can be subjected to temperatures in the normal sensitizing range of 550 to $1090^{\circ} \mathrm{C}$ for extended periods without undergoing severe corrosion attack.

As shown in Table 3, the compositions of Alloys C-4 and C-276 are, with the exception of iron and tungsten, about the same. Similarly, both alloys have about the same corrosion resistance. In strong reducing media such as hydrochloric acid, Alloy $\mathrm{C}-4$ has slightly higher rates than Alloy $\mathrm{C}-276$, but in oxidizing media the results are reversed. It would appear that these differences relate to the effects of iron and tungsten; the data arc noi conclusive, however. Alloy $\mathrm{C}-4$ offers good resistance to corrosion in a wide variety of media, including organic acids and acid chloride solutions.

\subsubsection{Alloy C-22}

Because Alloy C-22 has been developed recently, the literature on it is limited. The following material on Alloy C-22 is therefore taken from a product bulletin published by Haynes International, Inc. (Haynes 1988).

Alloy C-22 is a versatile Ni-Cr-Mo alloy with better overall resistance to corrosion than other Ni-CT-Mo alloys available today, including Alloys C-276, C-4, and 625 . Alloy C-22 has outstanding resistance to pitting, crevice corrosion and stress-corrosion cracking. It has excellent 
resistance to oxidizing aqueous media including wet chlorine and mixtures containing nitric acid or oxidizing acids with chloride ions. Also, Alloy C-22 has outstanding resistance to reducing aqueous media. Because of this versatility it can be used where "upset" conditions are likely to occur or in multipurpose plants.

Alloy C-22 has exceptional resistance to a wide variety of chemical process enviromments, including strong ox- idizers such as ferric and cupric chlorides, hot contaminated solutions (organic and inorganic), chlorine, formic and acetic acids, acetic anhydride, and seawater and brine solutions.

Alloy C-22 resists the formation of grain-boundary precipitates in the weld heat-affected zone, thus making it suitable for most chemical process applications in the as-welded condition.

\section{Phase Stability}

This section discusses thie phase stability of the $\mathrm{Ni}$ $\mathrm{Cr}$-Mo alloys. Sections ? 1 and 2.2 discuss their phase stability in terms of the ternary $\mathrm{Ni}$-Cr-Mo phase diagram. Section 2.3 discusses the precipitates observed to form during aging surties of the commercial alloy systems-both precipicates that form at temperatures less than $600^{\circ} \mathrm{C}$ and at temperanures greater than $600^{\circ} \mathrm{C}$.

\subsection{The Ni-Cr-Mo Phase Diagram: The High-Nickel Portion}

None of the commercial $\mathrm{Ni}-\mathrm{Cr}$-Mo alloys are strictly ternary systems (see Table 6). They all contain minor alloying constituents and impurities, which may signinicantly affect the phases (or $p$ :ecipitates) that form. In spite of this limitation, the high-nickel portion of the temary $\mathrm{Ni}-\mathrm{Cr}-\mathrm{Mo}$ phase diagram serves as a basis for discussing the stabi' ity of the commercial alloys.

The Ni-Cr-Mo system has been extensively reviewed by Jena et al. (1989). These authors discuss the entire composition range of this system. Here, however, only the high-nickel portion of the phase diagram is discussed because the alloys of interest all have nickel concentrations of $50 \mathrm{wt} \%$ or more. Several investigations have characterized the phase fields of the Ni-Cr-iilo ternary system (Rideout et al. 1951, Bloom and Grant 1954, Class et al. 1962, Raghavan 1984). In the ternperature range of $120 \mathrm{n}$ to $1250^{\circ} \mathrm{C}$, the nickelrich regions of the phase diagrams are all very similar (see Figs. 1 through 4). All of the investigations show that for nickel concentrations greater than about 55 to $60 \mathrm{wt} \%$, the system is single-phase austenite $(\gamma)$.

The reported $\mathrm{Ni}-\mathrm{Cr}$-Mo phase diagrams all have phase fields adjacent to the $\gamma$ phase field that are also similar except for the high chromium concentrations. From the high molybdenum to the high chromium at nearly constant nickel, the phase fields change from two-phase $\delta+\gamma$, to three-phase $\delta+P+\gamma$, to two-phase $\mathrm{P}+\gamma$, to three-phase $\mathrm{P}+\sigma+\gamma$, to two-phase $\sigma+\gamma$, to the region of some discrepancy. This region is not of concern beciuse the chromium concentrations are much higher than those of the alloys being considered. Likewise, the high-molybdenum $\delta$ phase is not of concern.

Lower-temperature isothermal sections of the phase diagram have also been obtained (Raghavan 1984, Class et al. 1962). These studies show that the $\gamma$ field is significantly reduced as the temperature is lowered (Fig. 5). Although there is a rather large discrepancy between the investigations as to the magnitude of this effect, the important effect is that as the temperature is lowered the single-phase $\gamma$ field is reduced.

There are significant changes in the phase fields for the lower-temperature isotherm $\left(850^{\circ} \mathrm{C}\right)$ of the $\mathrm{Ni}$ $\mathrm{Cr}$-Mo phase diagram. A major change is the emergence of the $\mu$ phase (Fig. 6). The two-phase $\gamma+\mu$ fitid occurs in the region of the phase diagram held by the two-phase $\gamma+P$ at $1250^{\circ} \mathrm{C}$. The $\mathrm{P}+\gamma$ field is significantly reduced and shifted to higher chromium concentrations. Likewise, the $\sigma+\gamma$ field is shifted to higher ihromium concentrations.

The $\sigma, \mathrm{P}$, and $\mu$ intermetallic phases are all topolo fically close-packed (TCP) and have compositions that depend on the precipitation temperature and the alloy composition (see Figs. 4 and 6). The phase diagram indicates that the compositions of the intermetallics are higher in chromium and/or molybdenum and poorer in nickel compared with the compositions from which they precipitate. The $\mathrm{P}$ phase has an orthorhombic structure with few faults. The $\mu$ phase has a thombohedral crystal structure with extensive faults. The $\sigma$ phase has a tetragonal crystal structure with a higher fault density than the $\mathrm{P}$ phase. The types of faults present in the intermetallic phases were not specified.

\section{Estimated Phase Position of Cc. mercial Alloys}

Commercial alloys cannot be strictly located on the $\mathrm{Ni}-\mathrm{Cr}$-Mo phase diagram because these alloys are 


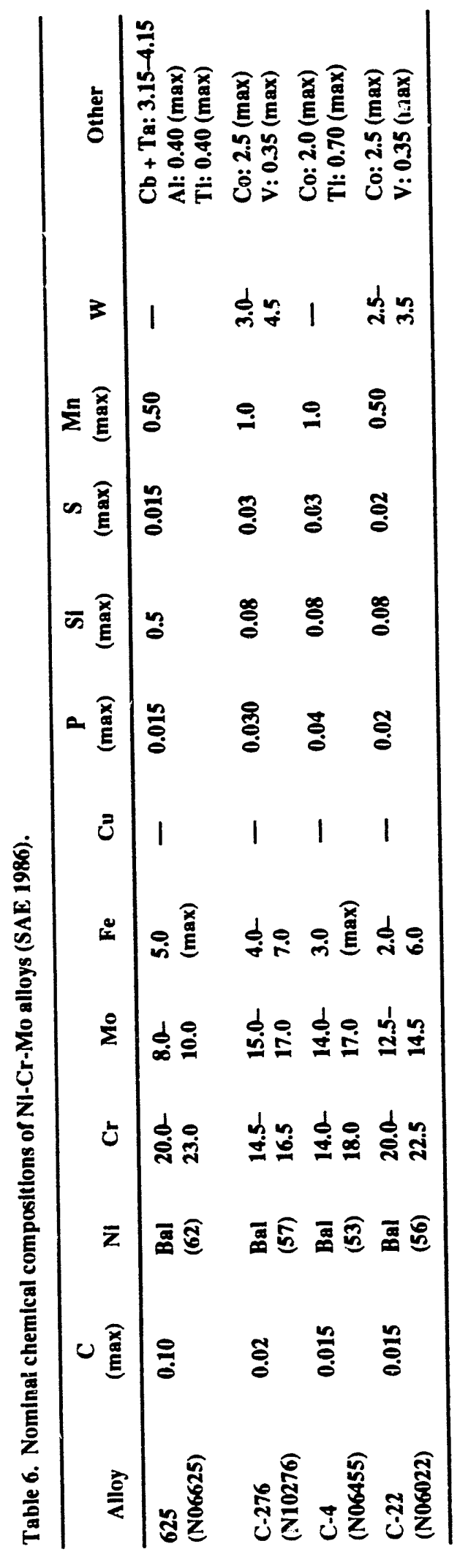


not pure ternary systems. To circumvent this limitation, the use of chromium, molybdenum, and nickel equivalents has been proposed (Cieslack et al. 1986). By correlating the behavior of the minor alloying elements (iron, titanium, cobalt, and tungsten) with the major elements in the formation of intermetallic precipitates, Cieslack et al. have proposed the following relationships for Alloys C-4, C-22, and C-276:

$$
\begin{aligned}
& \mathrm{Mo}_{\text {eq }}=w t \% \mathrm{Mo}+w t \% \mathrm{w}, \\
& \mathrm{Cr}_{\text {eq }}=w t \% \mathrm{Cr}, \\
& \mathrm{Ni}_{\text {eq }}=\mathrm{wt} \% \mathrm{Ni}+\mathrm{wt} \% \mathrm{Fe}+\sum \mathrm{wt} \% \mathrm{X}_{i},
\end{aligned}
$$

where $\sum \mathrm{wt} \% \mathrm{X}_{i}$ is the total remaining alloy content not included in the other equivalents. Weighting factors were not used bicause of the rather limited data available on these systems.

The equivalent compositions for Alloys C-4, C-22, $\mathrm{C}-276$, and 625 are plotted on isothermal sections of the $\mathrm{Ni}-\mathrm{Cr}$-Mo phase diagrams at 1250 and $850^{\circ} \mathrm{C}$ (Fig. 7). The points for Alloys C-276, C-22, and C 4 were calculated for actual alloy specimens (Cieslack et al. 1986), and the point for Alloy 625 was calculated by the author of the present report for a nominal composition
(Table 6). The point for Alloy 625 should be considered with caution because this alloy contains a significant addition of $\mathrm{Cb}+\mathrm{Ta}$ (3.15 to $4.15 \mathrm{wt} \%$ ), so it might not be appropriate to consider Alloy 625 on a $\mathrm{Ni}-\mathrm{Cr}-\mathrm{Mo}$ phase diagram.

In addition to the nominal compositions, the segregation profiles resulting from solidification, in equivalent terms, are shown as the arrows associated with each nominal composition. (Alloy 625 was not included in the study that determined the segregation profiles.) The tail of each arrow represents the compositions of the initial solid to crystallize from the melt, that is, the dendrite core region. The head of each arrow represents the final solidification composition, that is, the interdendritic regions. Although all of the bulk equivalent compositions lie within the single-phase $\gamma$ field at $1250^{\circ} \mathrm{C}$, the final solidification compositions for Alloys C-22 and C-276 are located within fields of TCP phase stability.

As the temperature is lowered, the TCP phasestability fields approach the nominal compositions of the alloys. At $850^{\circ} \mathrm{C}$, the nominal compositions of Alloys C-22 and C-276 are contained in or border on the TCP phase fields, while the nominal compositions of Alloys $\mathrm{C}-4$ and 625 are still contained in the singlephase $\gamma$ field (Fig. 7). (Note that an earlier proposed

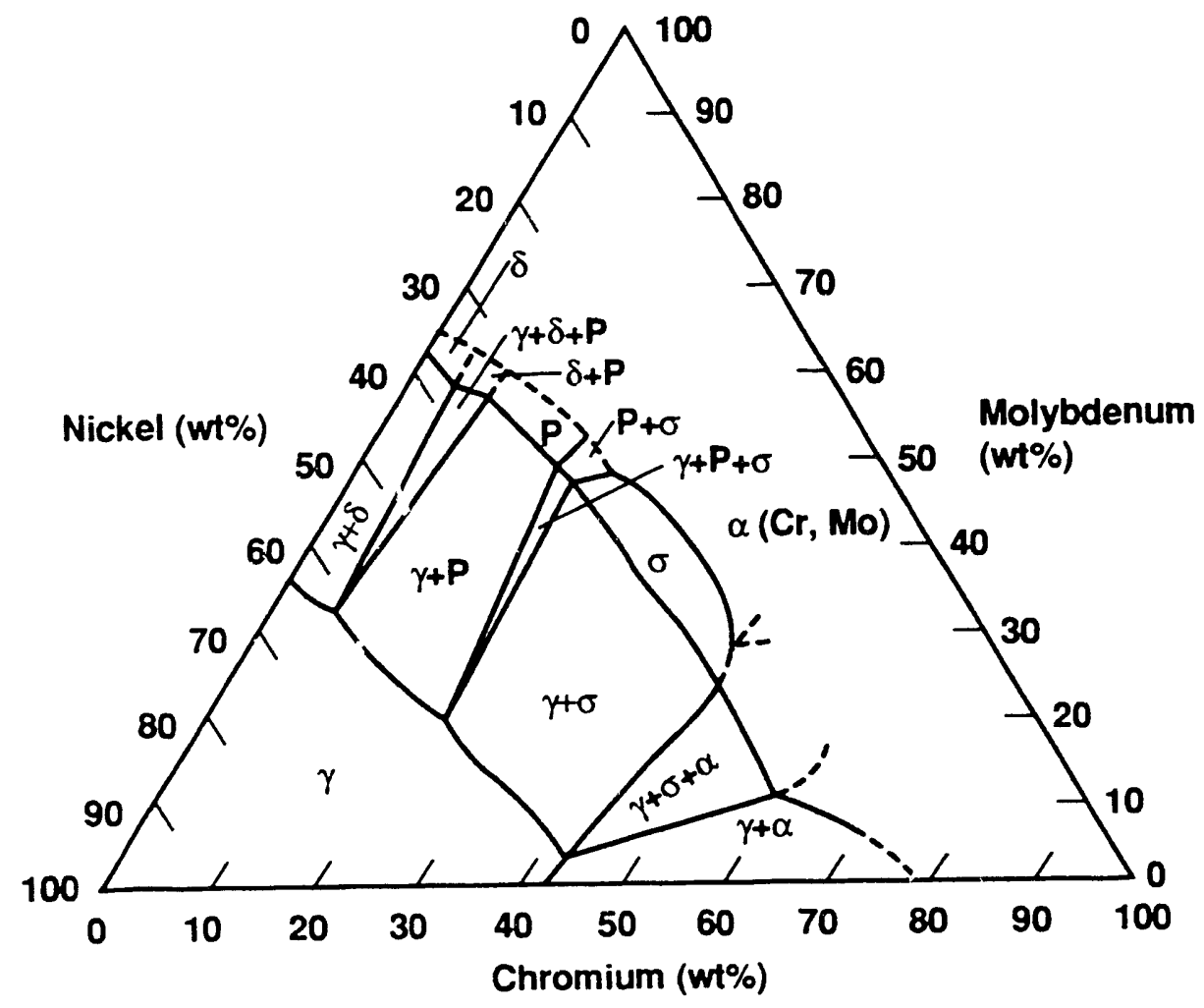

Figure $1.1200^{\circ} \mathrm{C}$ section of the $\mathrm{Ni}-\mathrm{Cr}$-Mo system (Rideout et al. 1951). 


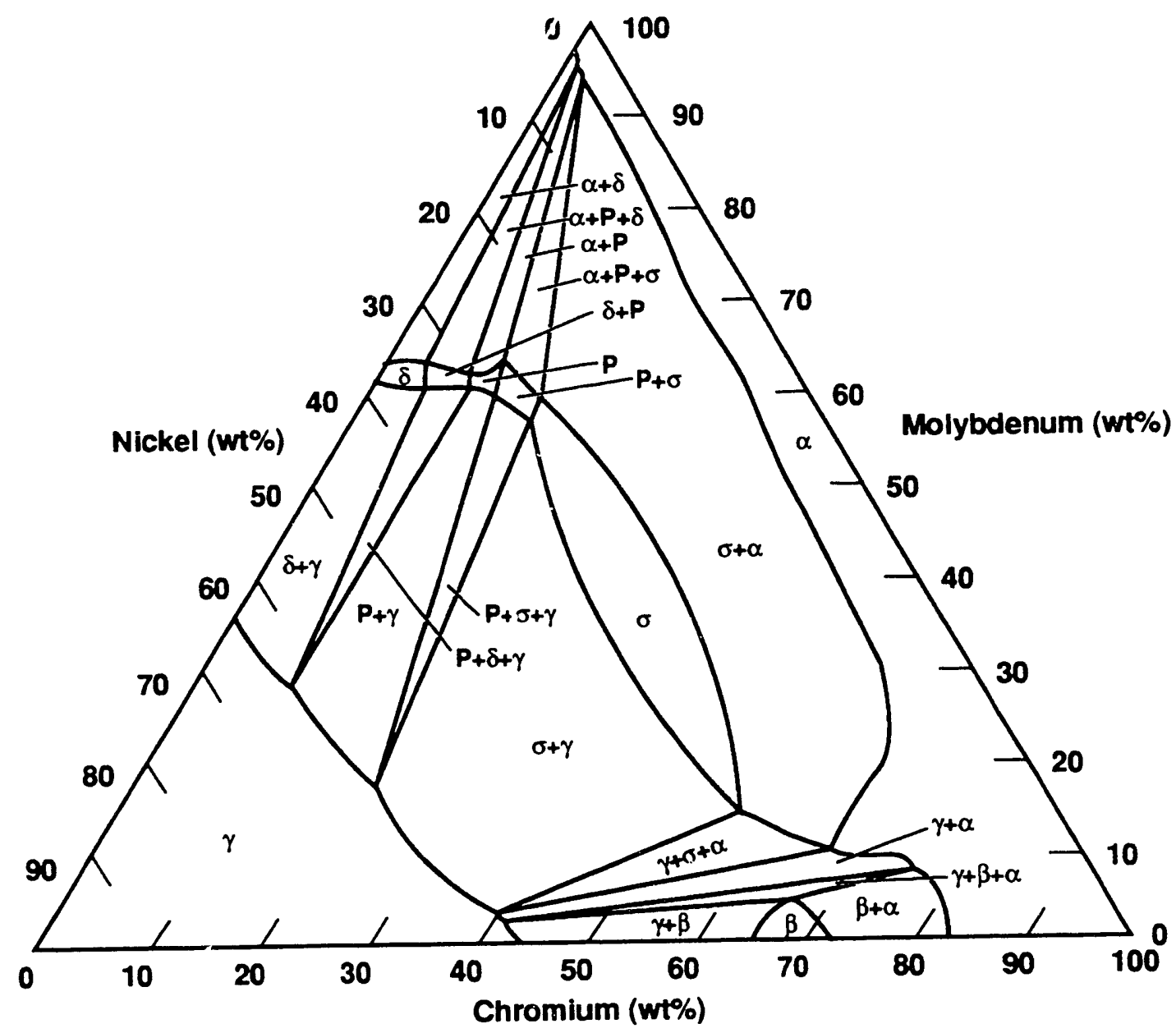

Figure 2. $1250^{\circ} \mathrm{C}$ section of the $\mathrm{Ni}-\mathrm{Cr}-\mathrm{Mo}$ system, showing the '. eats used to determine the section (Bloom and Grant 1954).

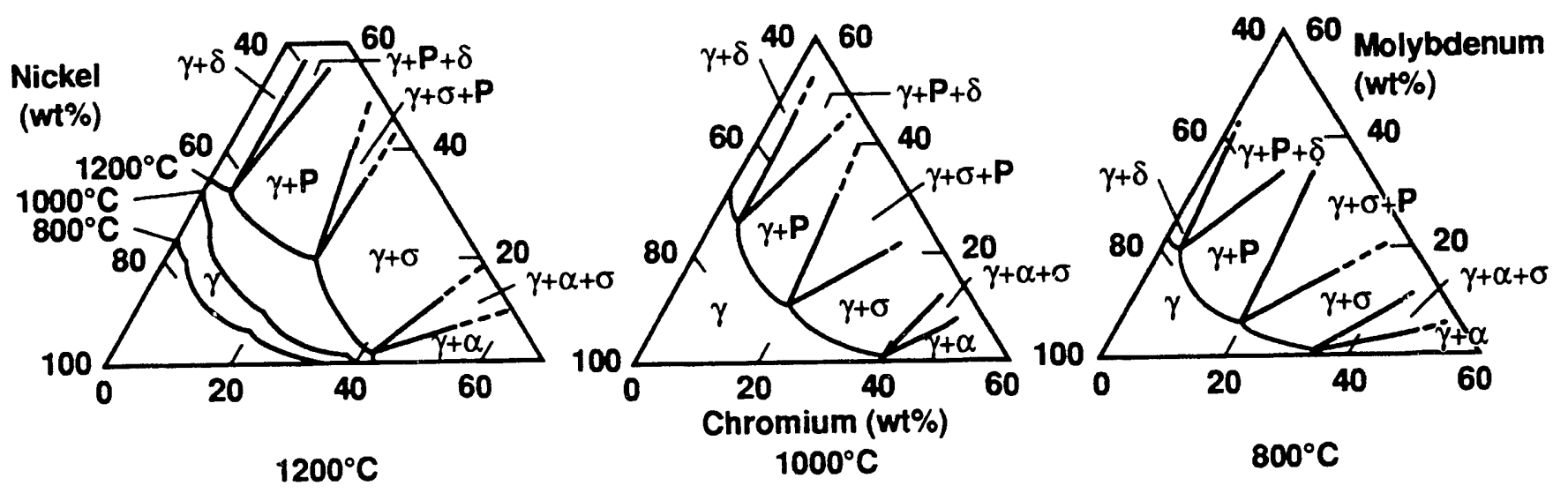

Figure 3. Isothermal sections of the Ni-Cr-Mo system at various temperatures (Class et al. 1962). 


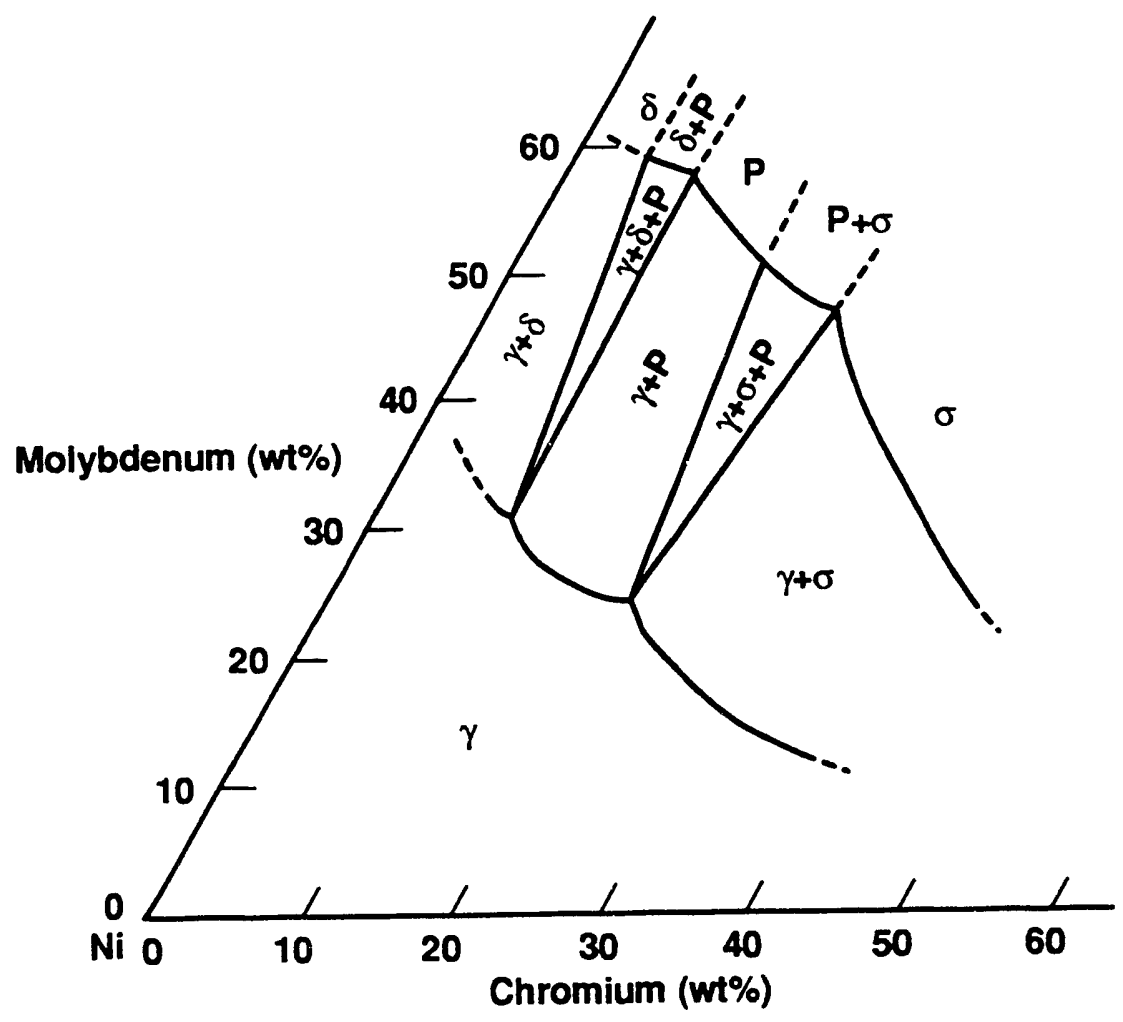

Figure 4. $1250^{\circ} \mathrm{C}$ section of the Ni-Cr-Mo ternary system (Raghavan et al. 1984).

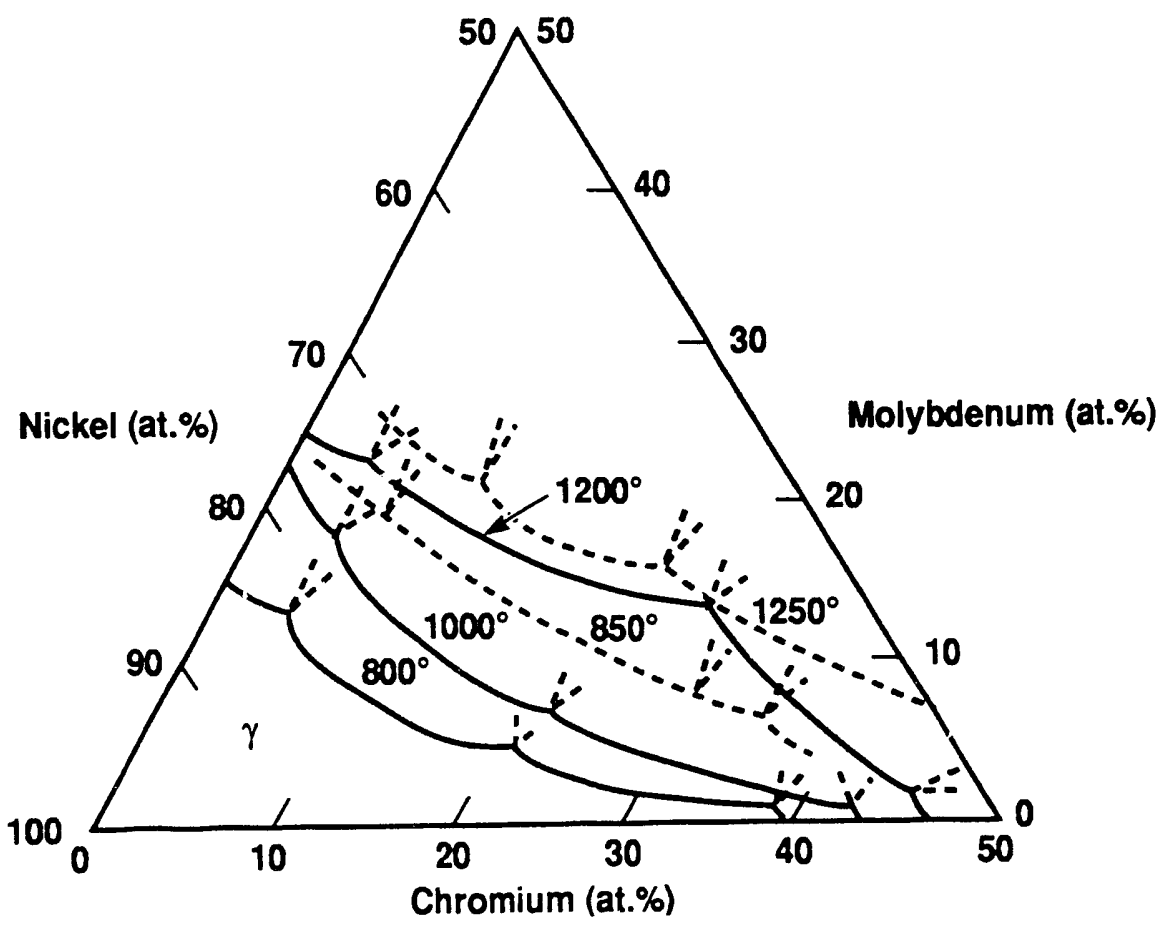

Figure 5. Gamma-phase boundaries at 1200,1000 , and $800^{\circ} \mathrm{C}$ in the $\mathrm{Ni}-\mathrm{Cr}-\mathrm{Mo}$ system. Solid curves are from Class et al. (1962), and dashed curves are from Raghavan et al. (1984). The figure has been redrawn from Jena et al. (1989). 


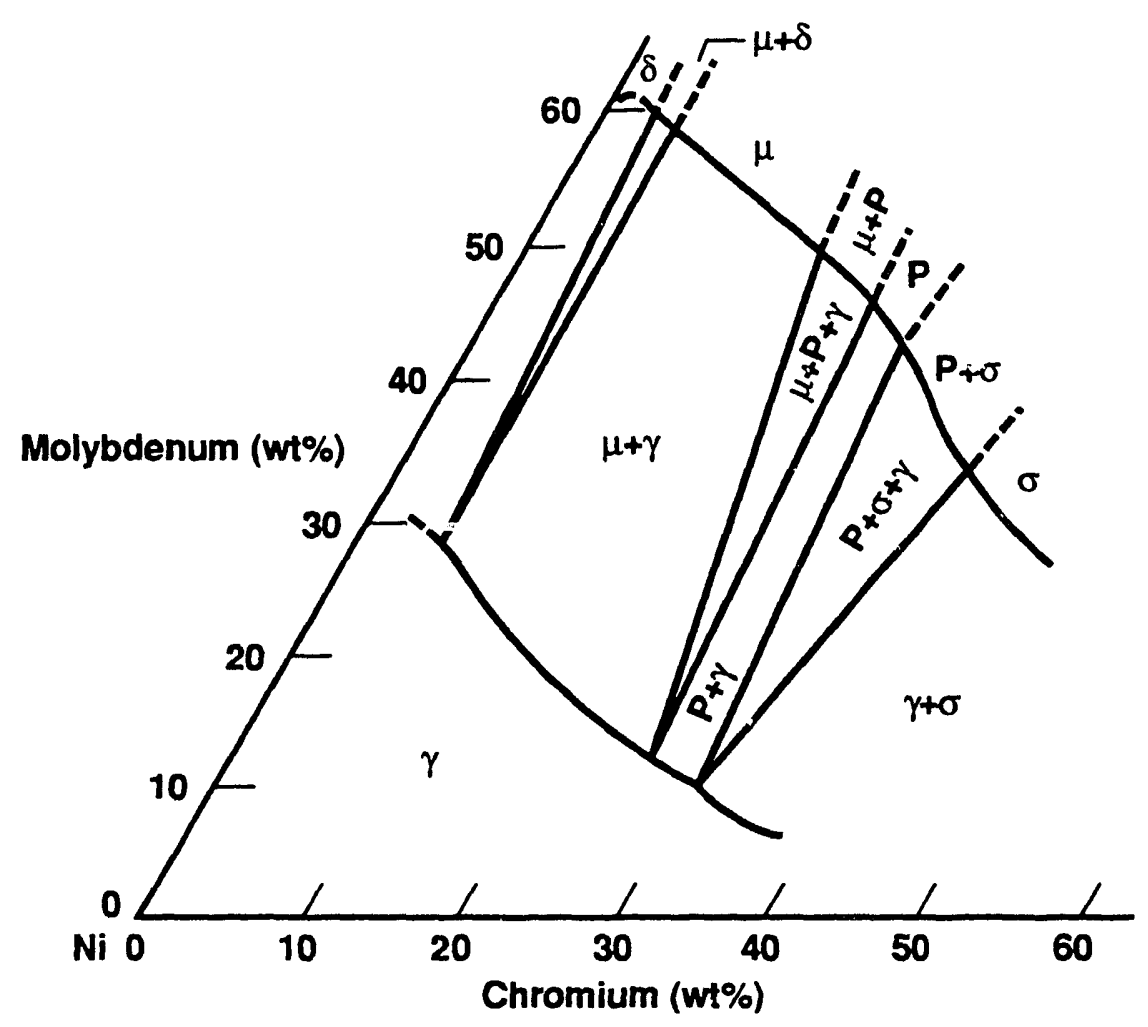

Figure 6. $850^{\circ} \mathrm{C}$ section of the Ni-Cr-Mo ternary system (Raghavan et al. 1984).

Raghavan et al. (1984)
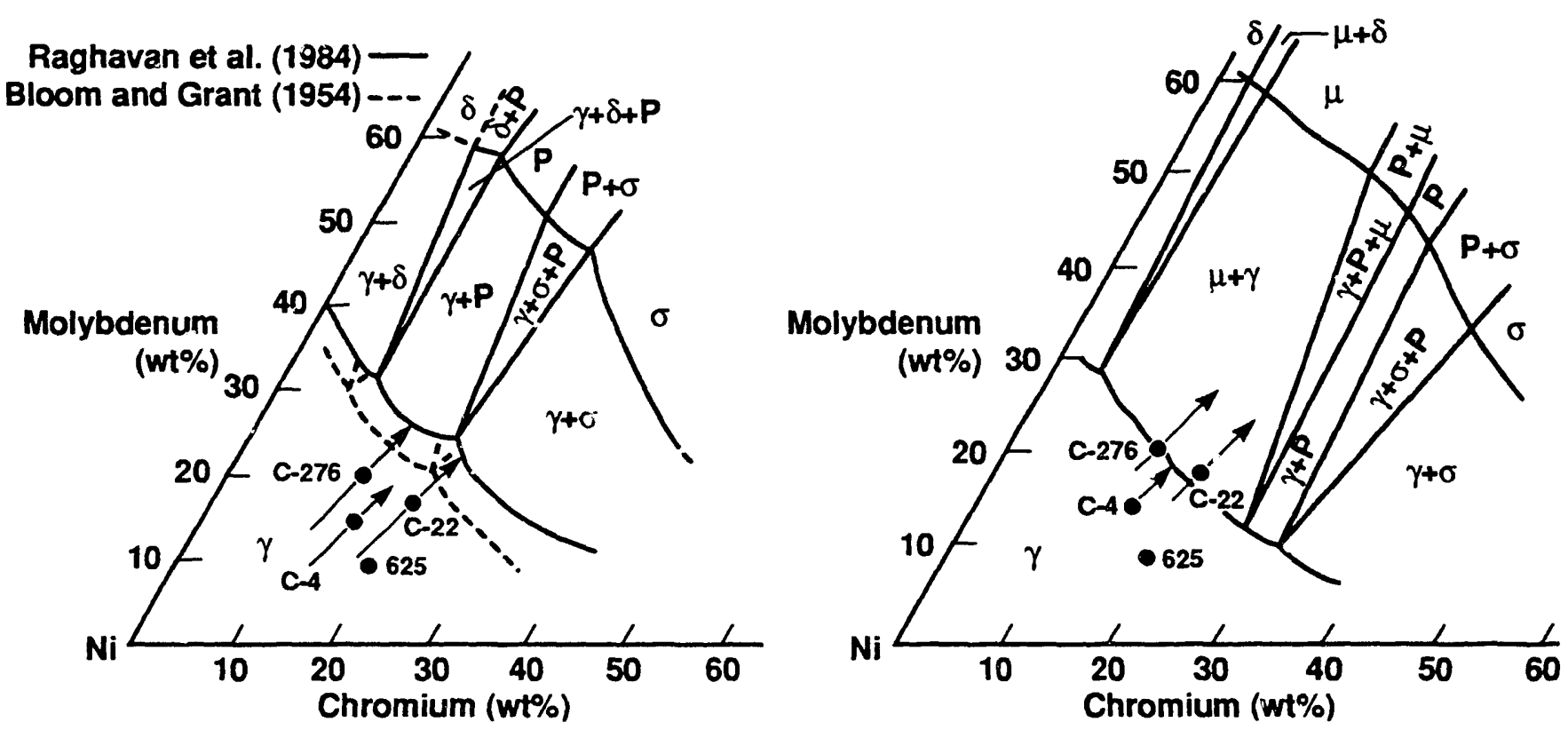

Figure 7. Isothermal sections showing the nominal equivalent solidification profiles (arrows) at (left) $1250^{\circ} \mathrm{C}$, and (right) $850^{\circ} \mathrm{C}$ (Cieslak et al. 1986). 
phase diagram (Class et al. 1962) predicted that all of the nominal compositions of the alloys would be in or near the multiphase fields at $800^{\circ} \mathrm{C}$.)

\subsection{Aging (Precipitation) Studies}

The effects of long-term aging (300-1000 yr) of the candidate alloys at low temperature $\left(50-250^{\circ} \mathrm{C}\right)$ need to be considered in catermining their suitability as high-level radioactive-waste containers. Some aging studies of the Ni-Cr-Mo alloys conducted at a relatively low temperature $\left(\geq 500^{\circ} \mathrm{C}\right)$ have shown that adverse changes $\propto$ ccur in the alloys' mechanical properties and corrosion resistance. These topics are discussed in this section. The susceptibility of the aged alloys to SCC and hydrogen embrittlement (HE) is presented in Secs. 3 and 5.

This section discusses (1) the precipitation of intermetallic phases, both within grains and on grain boundaries, and (2) the segregation of minor alloying and impurity elements to surfaces. It is divided into two subsections on the basis of temperature. Below $600^{\circ} \mathrm{C}$, surface segregation of certain elements and ordering of the alloy ociur before precipitation of intermetallic phases. Above $6 \hat{6} 0^{\circ} \mathrm{C}$, precipitation of intermetallics and carbides occurs. Surface segregation of certain elements also occurs above $600^{\circ} \mathrm{C}$, but ordering of the alloy does not.

Carbide phases do precipitate in mill-annealed and solution-annealed specimens. These carbide phases are called "primary" precipitates (Sims 1966) to distinguish them from other phases that precipitate after aging at elevated temperatures (but below the solution-annealing temperature); these are designated "secondary." The primary precipitates are usually carbides of $\mathrm{M}_{6} \mathrm{C}$ and/or MC. Monocarbides mainly form with titanium and niobium, but substitution of molybdenum or tungsten, such as in $\mathrm{Ti}(\mathrm{Mo}) \mathrm{C}$, may occur. (Alloy $\mathrm{C}-4$ has some $\mathrm{TiC}$ because of its $0.7 \mathrm{wt} \%$ titanium addition.) This carbide is fcc with lattice parameters much larger than those of the host lattice (Sims 1966). Carbides of $\mathrm{M}_{6} \mathrm{C}$ composition usually form in alloys containing about 6 to $8 \mathrm{wt} \%$ molybdenum plus its atomic equivalent in tungsten (fcc with $a=11.08 \AA$ ). The formation of $\mathrm{M}_{23} \mathrm{C}_{6}$ carbides in the 6- to 8-wt\% molybdenum alloys is suppressed in comparison with the $\mathrm{M}_{6} \mathrm{C}$ carbides.

\subsubsection{Temperatures Less $\operatorname{Than} 600^{\circ} \mathrm{C}$}

Below $600^{\circ} \mathrm{C}$, the limited data indicates that aging causes external surface and grain-boundary segregation of minor alloying and impurity elements, ordering of the major alloying constituents, and precipitation of grain-boundary carbides and intermetallics. All of these effects of aging have a temperature dependence, which controls the kinetic and equilibrium effects. Adverse changes in corrosion resistance and mechanical properties due to low-temperature aging have been reported in the Ni-Cr-Mo alloys. The changes in the mechanical properties are discussed here, while the changes in corrosion resistance are discussed briefly here and further in Secs. 3 and 5.

A few studies have investigated the segregation of minor alloying and impurity elements in Alloy C-276 (Burton et al. 1979, Berkowitz and Kane 1980). Berkowitz and Kane (1980) found phosphorus segregation to the fracture surfaces of Alloy C-276 using compositional analysis by Auger electron spectroscopy (AES). In this study, they analyzed the fracture surfaces after intergranular failure by HE in NACE solutions $\left(5 \% \mathrm{NaCl}\right.$ and $0.5 \% \mathrm{CH}_{3} \mathrm{COOH}$ saturated with $\left.\mathrm{H}_{2} \mathrm{~S}\right)$. Both commercial-purity Alloy C-276 $(0.025$ wt\% phosphorus) and low-phosphorus Alloy C-276 (0.002 wt\% phosphorus) were susceptible to $\mathrm{HE}$ following low-temperature aging, although the lowphosphorus alloy was more resistant to HE (see Sec. 5). The commercial-purity alloy showed significant segregation after $20 \mathrm{~h}$ at $371^{\circ} \mathrm{C}$.

An AES study of the external surface composition of Alloy C-276 showed that the segregation process is complex. It depends on five factors: kinetic limitations, thermodynamic temperature effects, cold-work annealing, depletion of trace impurities, and solute interactions (Burion et al. 1979). (The authors suggest that the external surface behavior may reflect the grain-boundary behavior of the alloy.) The study was performed at temperatures between 100 and $900^{\circ} \mathrm{C}$. Species that segregated to the sample surface were carbon, nitrogen, oxygen, phosphorus, sulfur, and silicon. Figure 8 shows surface-impurity concentrations as a function of 1-h anneal at various temperatures. All of the elements except sulfur have a maximum in surface concentration at some intermediate temperature $\left(300\right.$ to $\left.800^{\circ} \mathrm{C}\right)$. The concentration of sulfur, on the other hand, goes through a local maximum near $300^{\circ} \mathrm{C}$, but after a minimum at $400^{\circ} \mathrm{C}$ it keeps increasing with temperature.

According to Burton (1979), the five factors that control the surface segregation effects are

(1) Kinetic limitations. At low temperatures, diffusion is slow. As a result, the surface concentration of segregating impurities is low. As the temperature is raised, diffusion increases and the surface concentrations tend to increase.

(2) Thermodynamic effects. In dilute binary alloys, at equilibrium the surface concentration of a segregating element is high at low temperatures and low at high temperatures. 


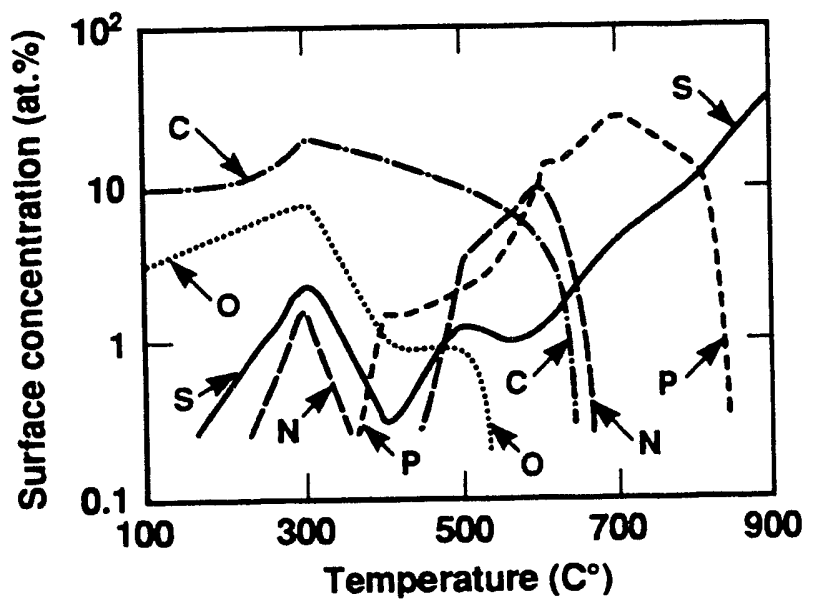

Figure 8. Surface composition of cold-reduced Alloy C-276 after initial 1-h anneals at increasing temperatures (Burton et al. 1979).

(3) Cold-work annealing. Diffusion is more rapid in a heavily damaged sample than in a well-annealed sample. As a result, at temperatures where surface compositions are kinetically controlled, increased amealing leads to decreased surface segregation.

(4) Depletion of trace impurities. Segregation can deplete the near surface region of trace impurity elements, leading to a reduction in the driving force for segregation.

(5) Segregating element interactions. Interaction of one segregating element with another can lead to either increased or decreased segregation.

In addition to causing the segregation of impurities to grain boundaries and external surfaces, aging causes the buik ordering of these alloys. Numerous studies have been undertaken to examine the effects of aging on susceptibility to HE (e.g., Sridhar et al. 1980, Asphahani et al. 1977). The physical changes to the materials were examined in these studies to find the cause of the increased susceptibility. It was found that aging primarily causes short-range and long-range ordering and segregation to surfaces.

The hardness of 50\% cold-worked Alloy C-276 has been found to increase with aging (from 42 to 46 Rockwell $\mathrm{C}$ scale) in the temperature range of 100 to $500^{\circ} \mathrm{C}$ (Fig. 9) (Sridhar et al. 1980). At 200 and $400^{\circ} \mathrm{C}$, hardness jumped within the first hour and then gradually increased with time. At $100^{\circ} \mathrm{C}$, the initial increase in hardness was not as large. At $700^{\circ} \mathrm{C}$, hardness significantly decreased within $2 \mathrm{~h}$ of aging. An annealed specimen did not show the dramatic increase in hardness with aging up to $100 \mathrm{~h}$ at $500^{\circ} \mathrm{C}$. Longer-term aging of a cold-worked specimen at $500^{\circ} \mathrm{C}$ showed that

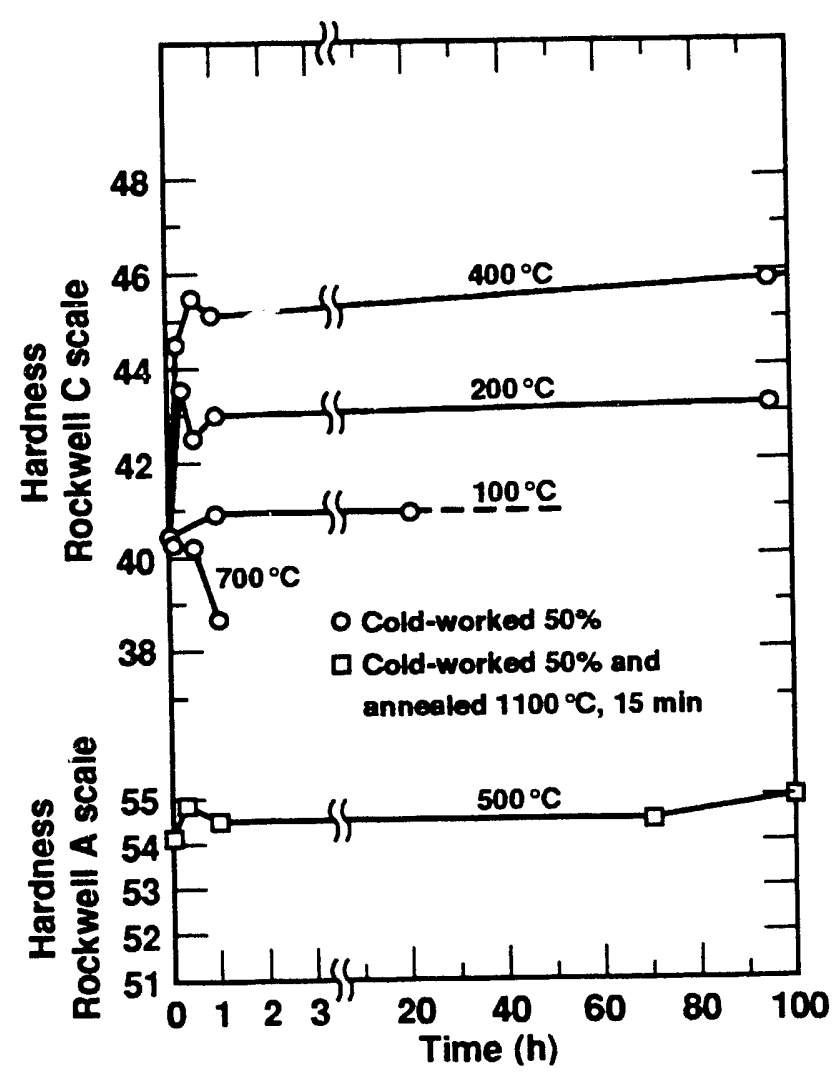

Figure 9. Effect of short aging times on the hardness of cold-worked and solution-annealed Alloy C-276 (Sridhar et al. 1980).

hardness increased more rapidly after $100 \mathrm{~h}$ and then reached a plateau after $400 \mathrm{~h}$ (Fig. 10).

Time-dependent variations in hardness have indicated the occurrence of microstructural changes upon aging (Sridhar et al. 1980). The initial sharp increase of hardness with aging can be due to either (1) segregation of solutes to dislocations and stacking faults, or (2) short-range ordering (SRO). In cold-worked materials, segregation and SRO can occur at times on the order of a few minutes because of the increased vacancy concentration. In annealed materials, however, fewer vacancies are present and slower effects would be expected. This expectation agrees with the data shown in Fig. 9.

The long-term aging of Alloys C-4 and C-276 at $540^{\circ} \mathrm{C}$ for more than $1000 \mathrm{~h}$ (42 days) has produced changes in morphology, mechanical properties, and corrosion resistance (Tawancy 1981, Tawancy et al. 1983, Raghavan et al. 1982). The alloys underwent a largevolume-fraction precipitation of a coherent long-rangeordered, orthorhombic $\mathrm{Pt}_{2} \mathrm{Mo}$-type phase. X-ray microanalysis showed no significant difference between 
Figure 10. Effect of $500^{\circ} \mathrm{C}$ aging time on Stage $I$ crack velocity, mean timeto-failure, and hardness of coldworked Alloy C-276 (Sridhar et al. 1980).

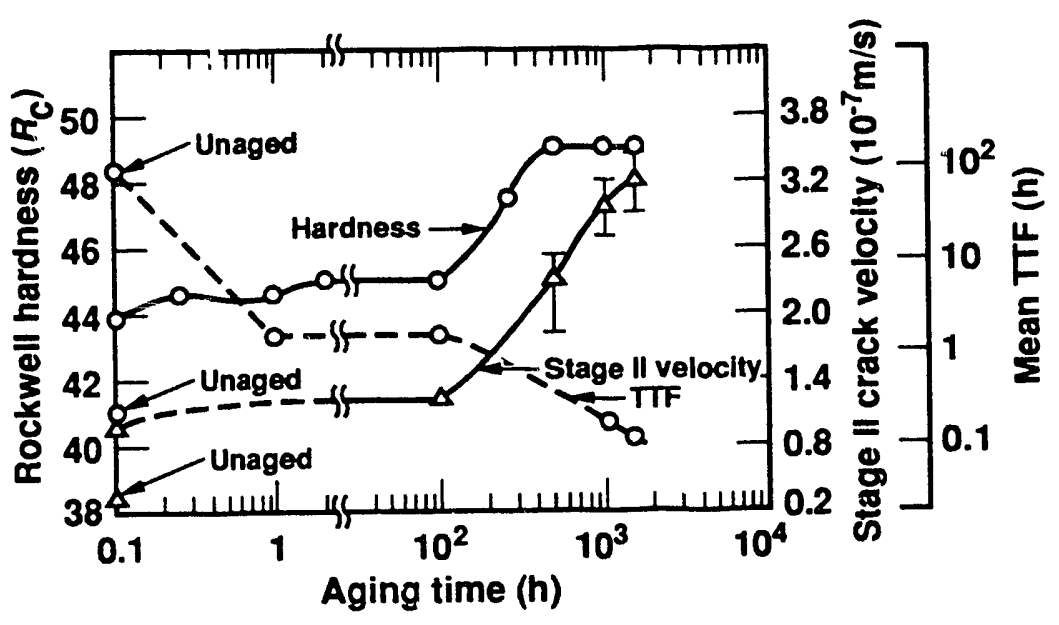

the bulk chemical composition of the disordered fcc phase and that of the ordered phase. On the basis of the chemistry of the alloys, the ordered phase was suggested to be of the form of $\mathrm{Ni}_{2}(\mathrm{Cr}, \mathrm{Mo})$. The ordered domains are in the form of ellipsoidal particles about $100 \AA$ in diameter. This precipitation reaction is homogeneous, with no preferential precipitation at the grain boundaries or twin boundaries.

In addition to undergoing ordering, the alloys were found to undergo grain-boundary precipitation reactions (Tawancy 1981). In Alloy C-4, a dispersed carbide was identified (probably $\mathrm{M}_{12} \mathrm{C}$ with lattice constant $10.89 \AA$ ). In Alloy C-276, the boundary precipitate was in the form of a continuous layer consisting of a molybdenum-rich carbide, $\mathrm{M}_{12} \mathrm{C}$, and a $\mu$ phase (isomorphous with $\mathrm{Fe}_{7} \mathrm{MO}_{6}$ ). The $\mu$ phase was assumed to nucleate from the carbides that are rich in iron and tungsten in addition to molybdenum.

These alloys were strengthened by the aging process at $540^{\circ} \mathrm{C}$ (see Fig. 11 and Table 7). During the period from 1000 to $2000 \mathrm{~h}$, the ultimate tensile strength (UTS) and the yield stress increased rapidly ( 30 to $40 \%$ increase), and the elongation decreased (30\%). After aging for $2000 \mathrm{~h}$, changes in the mechani$\mathrm{cal}$ properties were more gradual. After aging for $8000 \mathrm{~h}$, the yield strength had more than doubled and the UTS had increased by nearly $60 \%$, but the tensile elongation had decreased by more than $35 \%$. The fracture surfaces showed a mixture of intergranular and transgranular cracking, with aged Alloy C-276 exhibiting more intergranular cracking, presumably because of the continuous grain-boundary precipitation. The substructure of the tensile-tested specimens showed extensive deformation twins, suggesting that the observed strengthening upon ordering was due to a change in the deformation mode from slip to twinning, which usually requires greater stress.
Aging for $8000 \mathrm{~h}$ at $540^{\circ} \mathrm{C}$ affected the corrosion resistance of Alloy C-276 more than that of Alloy C-4 (Table 8). The corrosion rate of aged Alloy C-276 in boiling sulfuric-ferric sulfate was nearly 12 times greater than the rate of the solution-annealed alloy. The corrosion rate of aged Alloy C -4 was also greater than its rate in the solution-annealed state, but only by less than a factor of 2. The increased corrosion rate of Alloy C-276 was also attributed to the continuous grainboundary precipitation of the carbide and $\mu$ phase.

Temperature and cold-working have been found to affect the tendency of these alloys to form long-rangeordered structures (Tawancy 1983). Prior cold-work was found to accelerate the ordering kinetics, as evidenced by electron diffraction of samples given $60 \%$ cold reductions and then annealed for $100 \mathrm{~h}$ at $500^{\circ} \mathrm{C}$. Also, the order-disorder transition temperature in these alloys is in the temperature range of 550 to $600^{\circ} \mathrm{C}$. This means that above these temperatures the alloys will have no long-range ordering.

\subsubsection{Temperatures Greater Than $600^{\circ} \mathrm{C}$}

2.3.2.1 Alloy C. Alloy $\mathrm{C}$ is primarily a $\mathrm{Ni}-16 \mathrm{Cr}-$ $16 \mathrm{Mo}$ alloy with significant additions of minor alloying elements (ungsten, iron, and cobalt). The phase diagram for $\mathrm{Ni}-\mathrm{Cr}$-Mo indicates that at $1250^{\circ} \mathrm{C}$ Alloy $\mathrm{C}$ should have a single-phase $\gamma$ structure (Fig. 7). At $850^{\circ} \mathrm{C}$, there is a possibility of the precipitation of intermetallic phases. The precipitation of the intermetallic phases is accelerated by minor alloying elements, most particularly silicon and carbon (Class et al. 1962).

Several investigators have studied, in the temperature range of 480 to $1315^{\circ} \mathrm{C}$, the precipitation behavior of Ni-Cr-Mo alloys corresponding to Alloy C (Grafen and Bohm 1960, Class et al. 1962, Streicher 1963, Samans et al. 1966, Weisert 1957, Proetzl 1958). Generally, both intermetallic and carbide phases should 


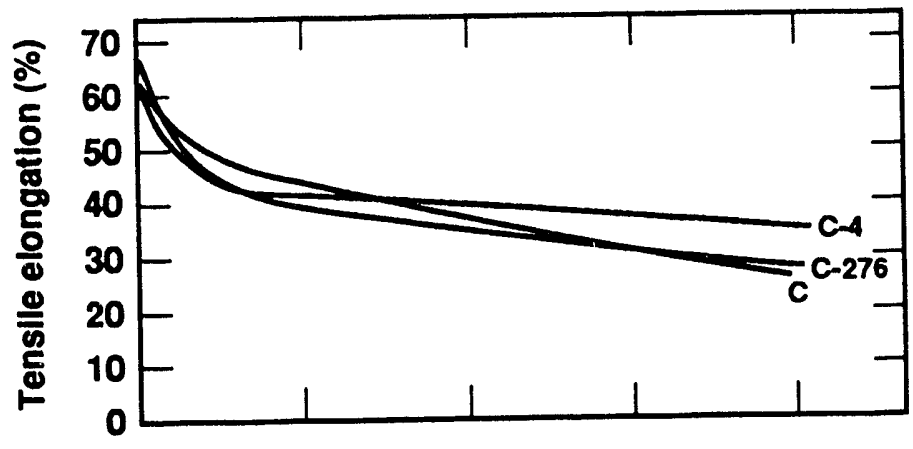

Figure 11. Effect of long-term exposure at $540^{\circ} \mathrm{C}$ on room-temperature tensile properties (Tawancy et al. 1983).
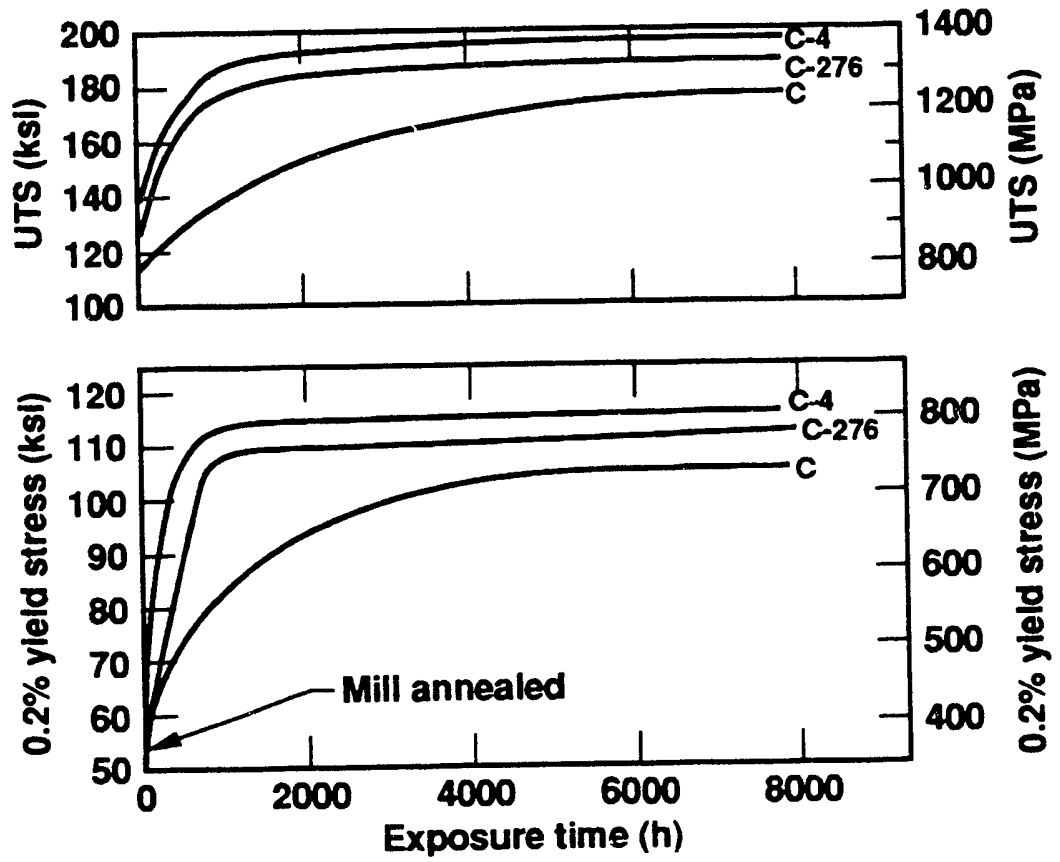

Table 7. Room-temperature tensile properties of Alloys C-4 and C-276 (Tawancy 1981).

\begin{tabular}{|c|c|c|c|c|}
\hline Alloy & Condition & $\begin{array}{l}0.2 \% \\
\text { yield } \\
\text { stress } \\
(\mathrm{ksi})\end{array}$ & $\begin{array}{l}\text { Ultimate } \\
\text { tensile } \\
\text { strength } \\
\text { (ksi) }\end{array}$ & $\begin{array}{c}\text { Tensile } \\
\text { elongation } \\
(\%)\end{array}$ \\
\hline$C-4$ & Annealed & 55 & 123 & 55 \\
\hline$C-4$ & $\begin{array}{l}\text { Annealed and } \\
\text { aged } 8000 \mathrm{~h} \\
\text { at } 540^{\circ} \mathrm{C}\end{array}$ & 116 & 197 & 35 \\
\hline C-276 & Annealed & 52 & 116 & 62 \\
\hline C-276 & $\begin{array}{l}\text { Annealed and } \\
\text { aged } 8000 \mathrm{~h} \\
\text { at } 540^{\circ} \mathrm{C}\end{array}$ & 112 & 180 & 28 \\
\hline
\end{tabular}

Table 8. Corrosion rates of Alloys C-4 and C-276 in boiling $50 \%$ sulfuric acid with $42 \mathrm{~g} / \mathrm{l}$ ferric sulfate (Tawancy 1981).

\begin{tabular}{llc}
\hline Alloy & \multicolumn{1}{c}{ Condition } & $\begin{array}{c}\text { Corrosion rate } \\
(\mathrm{mm} / \mathrm{yr})\end{array}$ \\
\hline $\mathrm{C}-4$ & Annealed & 3.3 \\
$\mathrm{C}-4$ & $\begin{array}{l}\text { Annealed and aged } \\
\text { 8000 h at } 540^{\circ} \mathrm{C}\end{array}$ & 5.4 \\
$\mathrm{C}-276$ & Annealed & 5.7 \\
$\mathrm{C}-276$ & $\begin{array}{l}\text { Annealed and aged } \\
8000 \mathrm{~h} \text { at } 540^{\circ} \mathrm{C}\end{array}$ & 67.5 \\
& & \\
\hline
\end{tabular}


Table 9. Characterization of precipitates in Alloy C.

\begin{tabular}{|c|c|c|c|c|}
\hline Author & Precipitate & Temp $\left({ }^{\circ} \mathrm{C}\right)$ & Sites & Comments \\
\hline $\begin{array}{l}\text { Weisert } \\
\text { (1957) }\end{array}$ & $\begin{array}{l}\mathbf{M}_{6} \mathbf{C} \text { and secondary } \\
\text { constituents }\end{array}$ & $1180-1220$ & $\begin{array}{l}\text { Within grains (only } \mathbf{M}_{6} \mathrm{C} \text { ), } \\
\text { within grains and on } \\
\text { grain boundaries }\end{array}$ & \\
\hline $\begin{array}{l}\text { Proetzl } \\
\text { (1958) }\end{array}$ & $\begin{array}{l}\mathbf{M}_{6} \mathrm{C}, \mathrm{M}_{23} \mathrm{C}_{6} \\
\mathrm{Mo}_{2} \mathrm{C} \text {, and } \sigma \text {-type }\end{array}$ & $<1140-1050$ & $\begin{array}{l}\text { Grain boundaries, } \\
\text { continuous or } \\
\text { discontinuous chain. } \\
\text { type structure }\end{array}$ & $\begin{array}{l}\text { No tungsten } \\
\text { Higher iron content } \\
\text { than standard Alloy C }\end{array}$ \\
\hline $\begin{array}{l}\text { Grafen and Bohm } \\
\text { (1960) }\end{array}$ & $\sigma$ type & 704-1038 & Grain boundaries & $\begin{array}{l}\text { Decreased } \mathrm{Mo}, \mathrm{Cr} \\
\text { on grain boundaries }\end{array}$ \\
\hline $\begin{array}{l}\text { Class et al. } \\
\text { (1962) }\end{array}$ & $\begin{array}{l}\mathrm{M}_{23} \mathrm{C}_{6} \text { and hexagonal } \\
\sigma \text { phase (Cr-Mo-Ni) }\end{array}$ & $500-1200$ & Grain boundaries & $\begin{array}{l}\text { Silicon was found to } \\
\text { increase precipitation } \\
\text { rate and stability } \\
\text { region of } \sigma \text { phase; } \\
\text { alloys had no tungsten }\end{array}$ \\
\hline $\begin{array}{l}\text { Streicher } \\
\text { (1963) }\end{array}$ & $\mathrm{Ni}_{7} \mathrm{Mo}_{6}$ & $\begin{array}{l}649-760 \\
760-1240\end{array}$ & $\begin{array}{l}\text { Grain boundaries } \\
\text { Grain boundaries, twin } \\
\text { boundaries, within grains }\end{array}$ & \\
\hline $\begin{array}{l}\text { Samans et al. } \\
\text { (1966) }\end{array}$ & $\begin{array}{l}\mathbf{M}_{6} \mathrm{C} \text { and precipitate } \\
\text { isomorphic with } \\
\text { (Fe,Co,Ni) }(\mathrm{Mo}, \mathrm{W})_{6} \\
\text { enriched in tungsten }\end{array}$ & $\begin{array}{l}1080-1150 \\
870-1080 \\
815-870 \\
675-815\end{array}$ & $\begin{array}{l}\text { Grain boundary } \\
\text { Continuous grain boundary } \\
\text { Within grains } \\
\text { Fine grain boundary }\end{array}$ & \\
\hline
\end{tabular}

form in the temperature range of 650 to $1200^{\circ} \mathrm{C}$, although there is some disagreement on the structure and composition of these phases (Table 9). The carbide phase has been variously identified as $\mathrm{M}_{6} \mathrm{C}, \mathrm{M}_{23} \mathrm{C}_{6}$, and $\mathrm{MO}_{2} \mathrm{C}$. The intermetallic phase has been variously referred to as $\sigma$ phase, $\mathrm{P}$ phase, $\mathrm{Ni}_{7} \mathrm{Mo}_{6}$ type, and 7-6 compound. The intermetallic phase was found to form primarily at grain boundaries of the material as a continuous or discontinuous chain-type structure. When present continuously, it caused intergranular attack of the alloy upon exposure to some severe corrosives.

The predominant elements in the intergranular phase, as shown by microanalyses of isolated particles, are nickel, molybdenum, and chromium. Depending on the composition of the alloy, the intergranular phase may also contain some iron and/or tungsten. The chromium and molybdenum contents of the intermetallics are substitutional within wide limits. In addition, the concentration of chromium and molybdenum in the intergranular phase is much higher than in the alloy matrix. This fact results in depletion of these elements in the areas adjacent to grain boundaries and may cause an increase in susceptibility to intergranular attack.
In studies of the effects of various $\sigma$-promoting elements that might be present in commercial alloys, it was found that silicon was the most effective $\sigma$-phase promoter (Grafen and Bohm 1960, Class et al. 1962). An alloy containing $0.61 \%$ silicon formed a continuous intergranular precipitate much more rapidly than an alloy with $0.01 \%$ silicon when both were heated at $970^{\circ} \mathrm{C}$. (Grafen and Bohm 1960). Studies such as these led to the development of the low-carbon, low-silicon version of Alloy C, which is called Alloy C-276.

2.3.2.2 Alloy C-276. As a result of several investigations, including those referred to above, a commercial modification of Alloy $\mathrm{C}$ was developed with lower silicon and carbon contents (maximum $0.05 \mathrm{wt} \%$ silicon and maximum $0.02 \mathrm{wt} \%$ carbon). The revised alloy is known as Alloy C-276. Leonard (1969) investigated the precipitation characteristics of a heat of Alloy C-276 ( $0.004 \mathrm{wt} \%$ carbon, $<0.01 \mathrm{wt} \%$ silicon) and showed that considerably more time at sensitizing temperature $(600$ to $1150^{\circ} \mathrm{C}$ ) is required to form precipitates in this alloy compared with a heat of Alloy C. At $870^{\circ} \mathrm{C}, 5 \mathrm{~min}$ was required to form precipitates in Alloy C-276, whereas precipitates appeared in Alloy $C$ within $10 \mathrm{~s}$ (Fig. 12). In another investigation (Kirchner and Silence 1971), after a 5-min heat treatment at $870^{\circ} \mathrm{C}$ Alloy C-276 


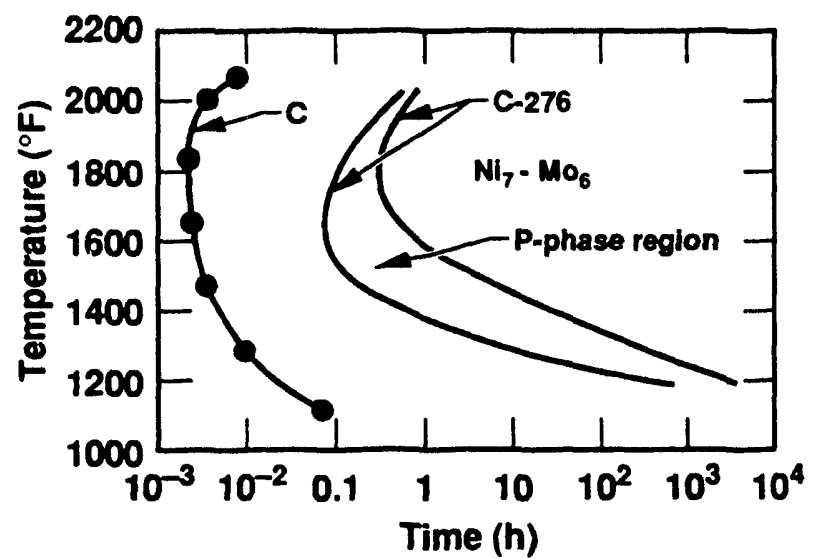

Figure 12. Comparison of the TTT curves of Alloys $C$ and C-276 (Leonard 1969).

showed slight precipitation of $\mathrm{M}_{6} \mathrm{C}$ and an intermetallic phase, while Alloy $\mathrm{C}$ showed heavy precipitation of $\mathrm{M}_{6} \mathrm{C}$ and an intermetallic phase.

The structure and precipitation sites of the intermetallic phase have been characterized (Hodge 1973). $\mathrm{X}$-ray diffraction and electron microprobe analysis of the intermetallic phase showed that it is a $\mathrm{Ni}, \mathrm{Fe}$, $\mathrm{Co})_{3}(\mathrm{~W}, \mathrm{Mo}, \mathrm{Cr})_{2} \mu$-phase possessing a rhombohedral/hexagonal structure. Electron microscopy and electron diffraction indicated that the intermetallics form as small globular particles both in the grain boundaries and in the grains. Certain particles in the grain boundaries exhibited, as a part of their intemal structure, growth bands. These were believed to be due to the intermetallic phase as opposed to the carbide
$\left(\mathrm{M}_{6} \mathrm{C}\right)$ because the hexagonal structure of the intermetallic phase would favor their development. A previous study had identified the intermetallic as either the $\mathrm{P}$ or Ni7Mo6 type (Leonard 1969).

The kinetics of the intermetallic phase precipitation were studied by measuring the volume fraction of this phase vs aging time at temperature for several heats of the alloy (Hodge 1973). The data indicated that a parabolic reaction mechanism is operative and yielded an activation energy of $62 \mathrm{kcal} / \mathrm{mol}$ when the volume fraction of the precipitate was plotted against reciprocal absolute temperature. Hodge pointed out that "the measured activation energy was observed to be between the published activation energy values for the diffusion of cobalt $(67 \mathrm{kcal} / \mathrm{mol})$, chromium $(66 \mathrm{kcal} / \mathrm{mol})$, nickel $(67 \mathrm{kcal} / \mathrm{mol})$, and tungsten $(71 \mathrm{kcal} / \mathrm{mol})$, and the values for iron $(51 \mathrm{kcal} / \mathrm{mol})$ and molybdenum $(51 \mathrm{kcal} /$ mol) in nickel. Such an observation is not unexpected since the intermetallic contains all six elements, and the overall activation energy might be expected to be a function of the individual values. When the individual activation energy values are weighed in accord with their atomic proportion in the $\mu$ phase, the calculated value is 63 to $64 \mathrm{kcal}$, which agrees well with the measured value of $62 \mathrm{kcal}$."

2.3.2.3 Alloy C-22. Alloy C-22 has generally tetter resistance to carbide and intermetallic precipitation than Alloy C-276. Alloy C-22 has more chromium and less molybdenum and iron than Alloy C-276. The diffcrence in the stability of the alloys is not apparent from the Ni-Cr-Mo phase diagrams (Fig. 7).

An isothermal time-temperature-precipitation diagram of solution-annealed Alloy C-22 (Fig. 13) indicates

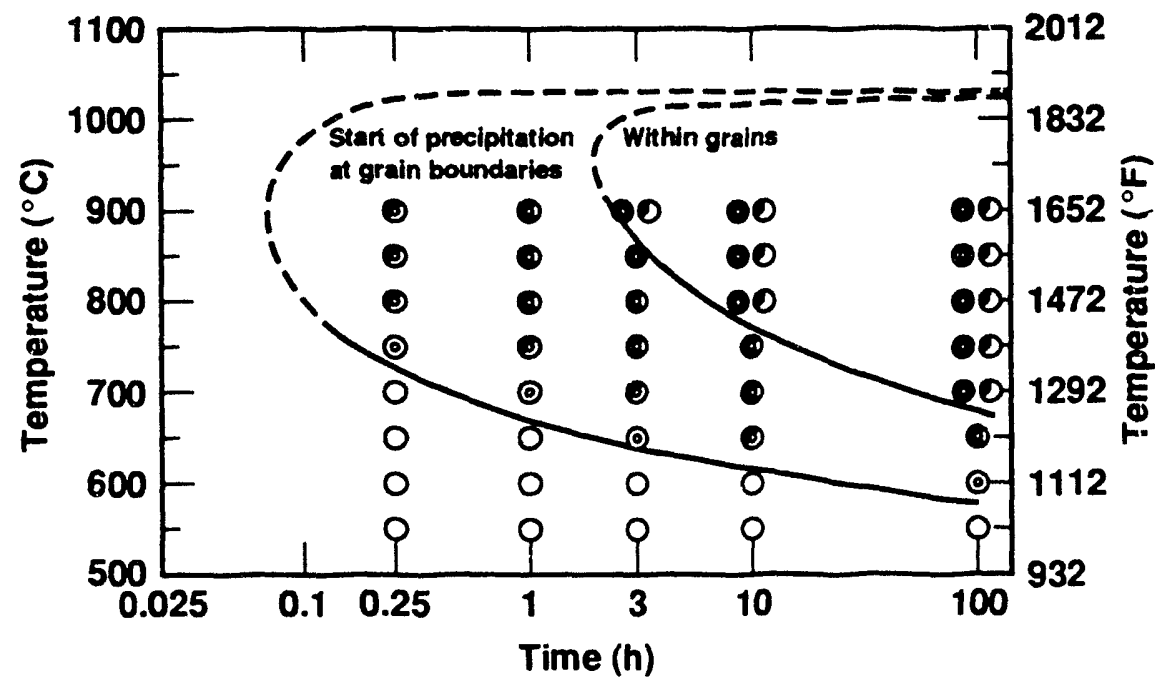

O Free from precipitates

๑ Precipltation starting at grain boundaries

(2) Some grain boundary precipltation

- Grain boundary precipitation still incomplete

Precipitation covers grain boundaries completely

- Some precipitation within the grains

Figure 13. Isothermal time-temperature-precipitation diagram of Alloy C-22, established using optical microscopy, for a heat with $21.3 \mathrm{wt} \%$ chromium, $13.4 \mathrm{wt} \%$ molybdenum, $2.5 \mathrm{wt} \%$ iron, $3.1 \mathrm{wt} \%$ tungsten, and 0.008 wt \% carbon (Heubner et al. 1989). 
that precipitation occurs first at grain boundaries and then within grains (Heubner et al. 1989). Precipitation begins within $0.25 \mathrm{~h}$ at 750 to $900^{\circ} \mathrm{C}$. The chemical composition of the precipitates was determined by microprobe analysis after $100 \mathrm{~h}$ at $900^{\circ} \mathrm{C}$, where the precipitates appeared to be coarse enough to give reliable results. The composition that was determined was 30 wt \% nickel, 16 wt\% chromium, 42 wt\% molybdenum, $1.5 \mathrm{wt} \%$ iron, and $9 \mathrm{wt} \%$ tungsten. The composition could be $\mu, \mathrm{P}$, or $\mathrm{M}_{6} \mathrm{C}$ phases. No microstructural analysis of the precipitates was performed. Sensitization was thought to be govemed more by intermetallic precipitates than by carbide precipitates. Eliminating tungsten from the alloy increased the sensitization time by an order of magnitude at $750^{\circ} \mathrm{C}$. By eliminating tungsten and reducing the iron content to $0.5 \mathrm{wt} \%$, a specimen was not sensitized within $100 \mathrm{~h}$. Reducing the carbon content from 0.010 to $0.007 \mathrm{wt} \%$ did not change sensitization behavior. Both tungsten and molybdenum strongly favor the formation of $\mathrm{M}_{6} \mathrm{C}$ carbides.

Microstructural analysis of this alloy was made during a study of its welding metallurgy (Cieslak et al. 1986). Subsequent to the welding of Alloy C-22, various secondary intermetallic solidification phases were found. Differential thermal analysis (DTA) indicated the formation of an intermetallic, probably the $\sigma$ phase, during cooling. Electron micrographs revealed the presence of the $\sigma$ phase and two other intermetallics, $P$ and $\mu$. The $P$ phase was assumed to form from $a$ solid state transformation of the $\sigma$ phase, and the $\mu$ phase from a solid state transformation of the $P$ phase. None of the transformations go to completion, so all three intermetallics are present upon cooling. That is, there is a nonequilibrium distribution of the intermetallic phases.

All three intermetallics, $\sigma, P$, and $\mu$, are TCP species. All of the intermetallics have less nickel (33 vs $57 \mathrm{wt} \%$ ), more molybdenum (36 vs $13 \mathrm{wt} \%$ ), more tungsten (5 vs $3 w t \%$ ), and about the same amount of chromiuni as in the bulk $\gamma$ phase. There are individual differences between the phases, and these reflect the relative stability regions on the phase diagrams (e.g., see Fig. 6). Increasing molybdenum and decreasing chromium concentrations tend to stabilize the $\mu$ phase relative to the $\mathrm{P}$ phase and the $\mathrm{P}$ phase relative to the $\sigma$ phase.

2.3.2.4 Alloy C-4. Alloy $\mathrm{C}-4$ is a wrought modification of Alloy C-276. It is used in corrosive applications involving fabrication in which an alloy must be held for longer time periods in the temperature range of 650 to $1090^{\circ} \mathrm{C}$, as in hot forging, forming, normalizing, stress relieving, or other heat treatments (Hodge and Kirchner 1976, Kirchner and Silence 1971). In addition to a significant lowering of the silicon and carbon contents in this alloy, there is a reduction of the iron content to $3 \mathrm{wt} \%$ maximum, no tungsten addition is made, and $0.70 \mathrm{wt} \%$ maximum titanium is added. This alloying combination has virtually eliminated the precipitation of the $\mu$ phase and significantly reduced carbide precipitation (Hodge and Kirchner 1976). The titanium is added to combine with carbon. Titanium is effective because of its low atomic weight and its affinity for nitrogen that may also be present. The titanium stabilization in Alloy C-4 does not occur in a manner analogous to that observed in stainless steels. Some titanium carbonitrides occur at random in the matrix during mill processing; however, not all carbon is removed from solution, and some $\mathrm{M}_{6} \mathrm{C}$ carbides can still form upon aging. The balance between $M(C, N)$ and $M_{6} C$ is a function of the total carbon content of the alloy as melted, but an exact relationship has not been developed (Hodge and Kirchner 1976). The composition ranges for this alloy are shown in Table 6.

Precipitation studies on Alloy $\mathrm{C}-4$ indicate that intermetallic precipitates, which occur in other $\mathrm{Ni}-\mathrm{Cr}$-Mo alloys, have been virtually eliminated for time periods less than $100 \mathrm{~h}$ (Hodge and Kirchner 1976, Kirchner and Silence 1971). Figure 14 shows TTT curves for Alloys C-4 and C-276 (Hodge and Kirchner 1976). At $800^{\circ} \mathrm{C}$, carbide precipitation was observed for Alloy C-276 after $10 \mathrm{~min}$, but no carbide precipitation was observed for Alloy $\mathrm{C}-4$ until after $4 \mathrm{~h}$. In addition, at $800^{\circ} \mathrm{C} \mu$-phase precipitation occurred at about $1 \mathrm{~h}$ for Alloy C-276 but was not observed up to $100 \mathrm{~h}$ for Alloy C-4. Figure 14 also shows the effect of precipitation on the corrosion resistance of the alloys. When Alloy C-276 is in the three-phase region, its corrosion resistance is reduced. Alloy $\mathrm{C}-4$, however, suffers little degrarlation of its corrosion resistance when it is exposed for $100 \mathrm{~h}$ in the range of 600 to $1000^{\circ} \mathrm{C}$.

The difference in precipitation kinetics is further illustrated by the types of precipitates formed upon annealing (Hodge and Kirchner 1976). After $100 \mathrm{~h}$ at $800^{\circ} \mathrm{C}$, Alloy $\mathrm{C}-276$ formed coarse globular $\mathrm{M}_{6} \mathrm{C}$ intergranular carbides and $\mu$-phase particles in both interand intragranular areas in the microstructure. In contrast, after $100 \mathrm{~h}$ at $800^{\circ} \mathrm{C}$, Alloy $\mathrm{C}-4$ exhibited only mu 1or grain-boundary $\mathrm{M}_{6} \mathrm{C}$ precipitation and no $\mu$-phase ,recipitation.

Extended annealing at elevated temperature, however, has caused the precipitation of an intermetallic species. Precipitation of the $\mu$ phase in Alloy $\mathrm{C}-4$ occurred after extended heat treatment $(\geq 1000 \mathrm{~h})$ in the $800^{\circ} \mathrm{C}$ temperature range (Matthews 1976 ).

2.3.2.5 Alloy 625. Investigations of the stability of Alloy 625 at high temperature have shown the 


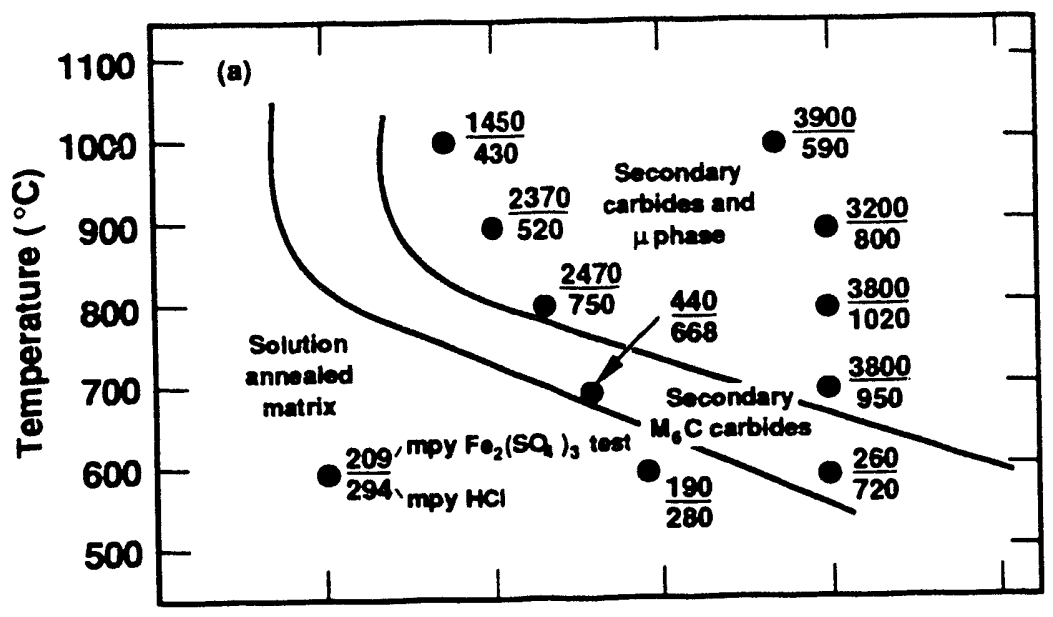

Figure 14. TTT diagrams for

(a) Alloy C-276, and (b) Alloy C-4

(Hodge and Kirchner 1976).

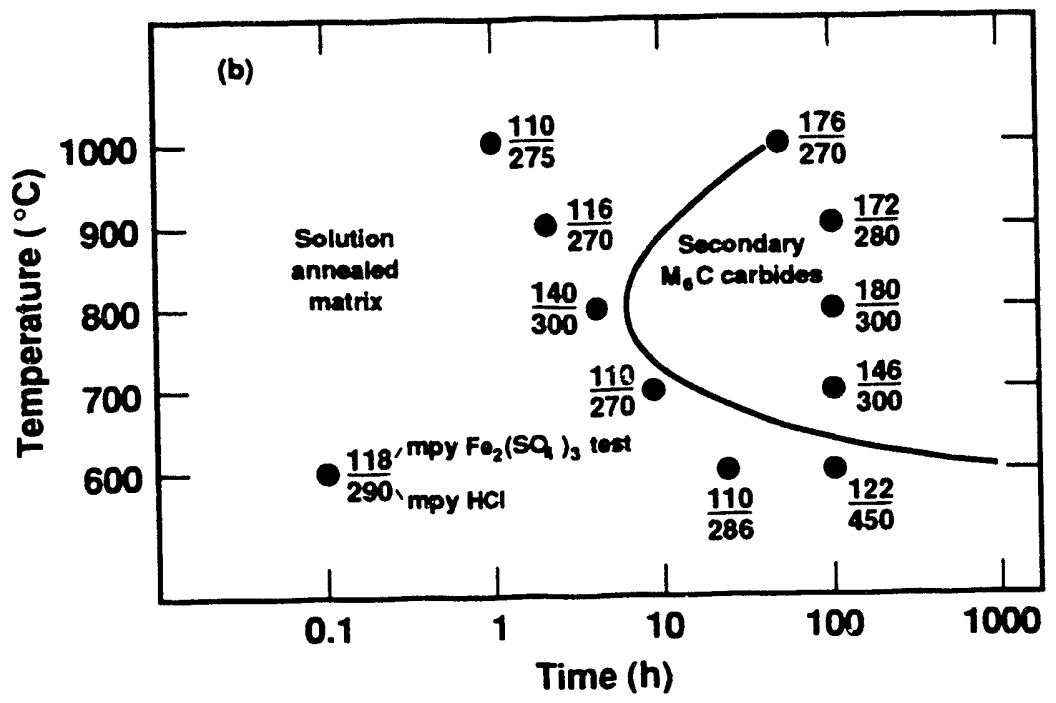

precipitation of carbide particles and the ordering of the alloy. However, the investigations indicate that the precipitation of intermetallics is difficult. None of the embrittling intermetallic phases such as $\sigma$ or $\mu$ were found after extended periods of heating at 590 to $930^{\circ} \mathrm{C}$ (Harris and Scarberry 1971). But a later study did report the precipitation of the $\delta$ phase after annealing at $750^{\circ} \mathrm{C}$ for $100 \mathrm{~h}$ but not after annealing at $700^{\circ} \mathrm{C}$ for $168 \mathrm{~h}$ (Dey et al. 1989).

Harris and Scarberry (1971) reported carbide precipitation in Alloy 625 following extended periods of heating in the temperature range of 590 to $930^{\circ} \mathrm{C}$. (The carbon content of the heat that was tested was $0.05 \mathrm{wt} \%$.) The carbides detected (MC, $\mathrm{M}_{23} \mathrm{C}_{6}$ and $\mathrm{M}_{6} \mathrm{C}$ ) were dependent on the thermal history of the specimen, which was aged in the temperature range of 650 to $930^{\circ} \mathrm{C}$ for 1 to $1000 \mathrm{~h}$ subsequent to $1-\mathrm{h}$ anneals at 1204 and $982^{\circ} \mathrm{C}$.
Foliowing the $982^{\circ} \mathrm{C}$ ( $1 \mathrm{~h}$ and water-quench) anneal, carbides were found to precipitate primarily within the grains in the temperature range of 650 to $930^{\circ} \mathrm{C}$. The $\mathrm{M}_{6} \mathrm{C}$ carbide was the predominant carbide precipitated. $\mathrm{A} \mathrm{Cb}(\mathrm{C}, N)$ species was also detected, but no $\mathrm{M}_{23} \mathrm{C}_{6}$ carbide was found. The primary metallic elements in the carbides were nickel, niobium, and molybdenum; chromium was found in smaller quantities in the carbides. The $\mathrm{M}_{6} \mathrm{C}$ carbide had the form $\mathrm{Vi}, \mathrm{Cb}, \mathrm{Mo})_{6}(\mathrm{C} N \mathrm{~N})$. For longer annealing times at the higher temper:aures, the $\mathrm{Cb}(\mathrm{C}, \mathrm{N})$ species concentration decreased.

Following the $1204^{\circ} \mathrm{C}(1 \mathrm{~h}$ and water-quench) anneal, carbides were found to precipitate primarily on grain boundaries in the temperature range of 650 to $930^{\circ} \mathrm{C}$. The $\mathrm{Cb}(\mathrm{C}, N)$ species was predominantly precipitated. For increasing precipitation times at temperatures above $816^{\circ} \mathrm{C}$, the $\mathrm{Cb}(\mathrm{C}, \mathrm{N})$ concentration 
Figure 15. TTT diagrams for Alloy 625 annealed at (a) $982^{\circ} \mathrm{C} / 30 \mathrm{~min}$ and water-quenched, and (b) $1204^{\circ} \mathrm{C} / 1 \mathrm{~h}$ and water-quenched (Harris and Scarberry 1971). Labeks are percent chromium in extracted carbide residues. Broken lines enclose areas of moderate sensitization and excessive sensitization.

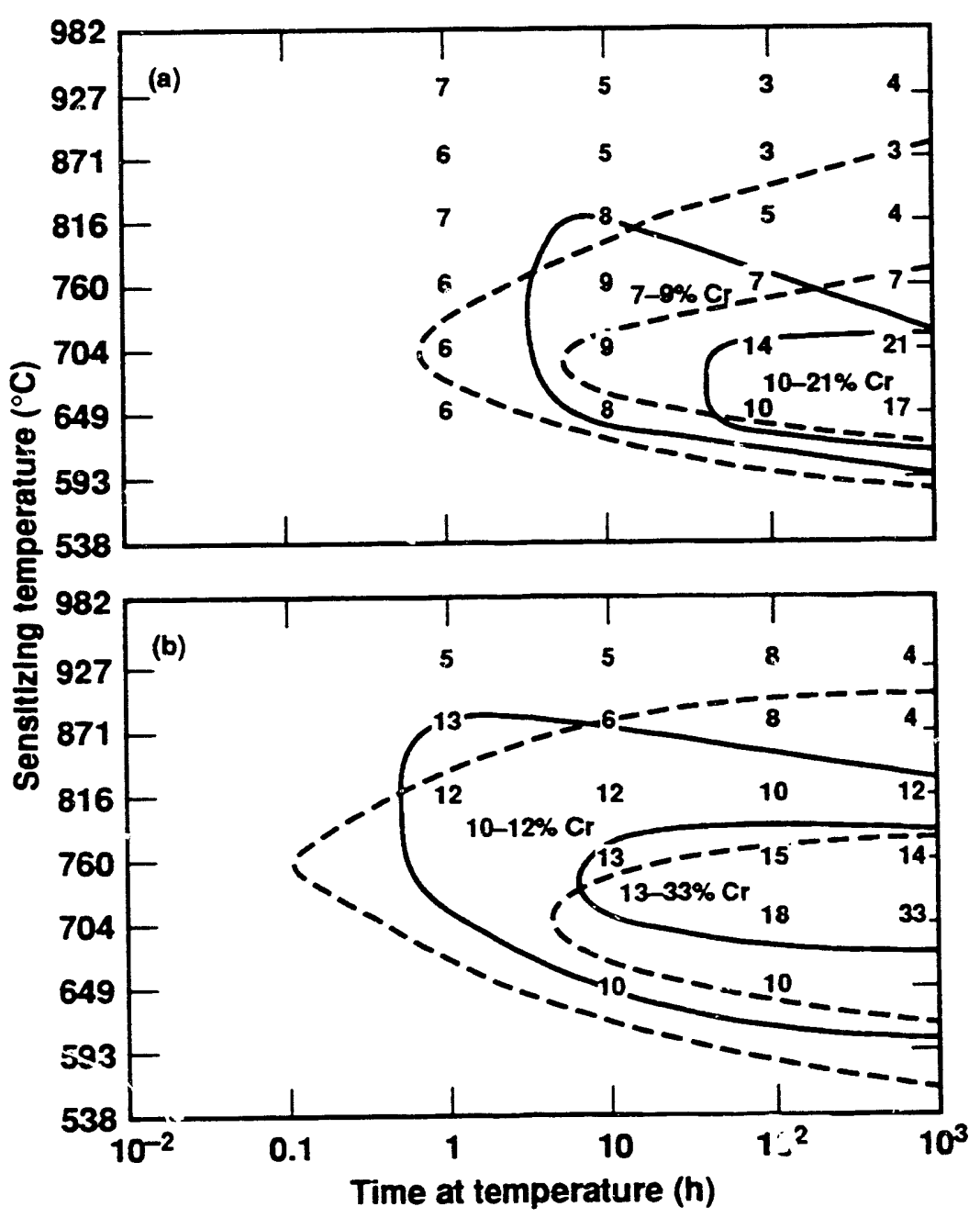

grain-boundary carbide precipitates to form with the subsequent sensitization. A $982^{\circ} \mathrm{C}$ anneal does not dissolve all of the $\mathrm{M}_{6} \mathrm{C}$ carbides, which are predominantly within grains. These carbides serve as nuscleation sites for further carbide formation during the sensitization treatment. This occurrence slows the precipitation of chromium-rich grain-boundary carbides and subsequent sensitization of the specimens (Fig. 15).

More recent work confirms the carbide precipitation behavior following a solution anneal (Dey et al. 1989). Annealing at $1100^{\circ} \mathrm{C}$ for $1 \mathrm{~h}$ followed by water quenching results in a nonuniform dispersion of primary MC particles at intergranular as well as intragranular locations. These carbide particles are not found to obey any preferred orientation with the matrix. Annealing at $700^{\circ} \mathrm{C}$ for 24 and $168 \mathrm{~h}$ results in light and heavy grain-boundary precipitation, respectivels; of $\mathrm{M}_{23} \mathrm{C}_{\delta}$ particles. In an earlier study, Alloy 625 showed similar behavior following $1-\mathrm{h}$ anneals at 
temperatures from 540 to $910^{\circ} \mathrm{C}$ (Brown 1969). Maximum sensitization was found to occur at $760^{\circ} \mathrm{C}$ using ASTM A262.

The carbon conient of the Alloy 625 heats tested in the experimental studies cited was $0.05 \mathrm{wt} \%$ (Harris and Scarberry 1971, Brown 1969). This carbon content is higher than what can be obtained with modern metallurgical techniques ( $0.02 \mathrm{wt} \%$ or lower). If the materials are properly heat treated, sensitization times are found to be much longer with lower carbon contents: $10 \mathrm{~h}$ at 650 to $900^{\circ} \mathrm{C}$ with $0.02 \mathrm{wt} \%$ carbon (Heubner et al. 1989). After a final stabilizing anneal, most of the carbon, which is present as an impurity, will be bound to columbium, and sensitization will occur only after annealing $10 \mathrm{~h}$ at 650 to $900^{\circ} \mathrm{C}$

During annealing at elevated temperatures, ordering of Alloy 625 occurs after carbide precipitation (Bohm et al. 1970, Dey et al. 1989). After annealing at temperatures of 675 to $825^{\circ} \mathrm{C}$ for extended periods (50 to $1000 \mathrm{~h}$ ), a metastable and coherent tetragonal phase, $\mathrm{Ni}_{3}(\mathrm{Cb}, \mathrm{X})$, forms. It is transformed at longer annealing times into a stable incoherent and orthorhombic $\mathrm{Ni}_{3}(\mathrm{Cb}, \mathrm{Mo})$ phase. A later study showed that these precipitates (referred to as $\gamma^{\prime \prime}$ ) were homogeneously nucleated and were disk-shaped (Dey et al. 1989). The particles were believed to precipitate quickly and only coarsen with time. Coarsening is believed to be bulkdiffusion-controlled (Bohm at al. 1970). Lattice vacancies are known to increase the rate of diffusion (Christian 1965), but they may also accelerate precipitation by lowering the free-energy barrier associated with precipicate nucleation (Russell 1969). In a niobiumbearing $\mathrm{Ni}-\mathrm{Cr}$-Fe matrix, enhanced $\gamma^{\text {" precipitation has }}$ beer, observed with increased vacancy concentration (Yurman and Warrington 1970).

\subsection{Summary}

The phase stability of the Ni-Cr-Mo alloys is ciependent on temperature. At or near solution-annealing temperatures $\left(1250^{\circ} \mathrm{C}\right)$, all of the $\mathrm{Ni}-\mathrm{Cr}$-Mo alloys appear to be single-phase $\gamma$. At $850^{\circ} \mathrm{C}$, however, Alloys C-276 and C-22 are estimated to be in or near multiphase fields. Alloy $\mathrm{C}-4$ is estimated to be within the $\gamma$-phase field. The analysis of Alloy 625 in terms of the
$\mathrm{Ni}-\mathrm{Cr}$-Mo phase diagram is not believed to be valid because of the significant alloying addition of $\mathrm{Cb}+\mathrm{Ta}$ (3.15-4.15 wt\%). For all of the alloys, quenching from high temperature $\left(1250^{\circ} \mathrm{C}\right)$ results in single-phase materials with carbide precipitates.

Carbides are present regardless of the technique used to quench from solution-annealing temperatures $\left(\geq 950^{\circ} \mathrm{C}\right.$ ). The type of carbide formed is dependent on the alloying constituents. Titanium in Alloy $\mathrm{C}-4$ and columbium in Alloy 625 form monocarbonitrides, which might be a mix of other metallic elements. Molybdenum in all of the alloys forms $\mathrm{M}_{6} \mathrm{C}$ carbides, which may incorporate a number of other metallic elements.

All of the Ni-Cr-Mo alloys are subject to enhanced grain-boundary carbide precipitation in the temperature range of 650 to $950^{\circ} \mathrm{C}$. The morphology of the carbide and the severity of sensitization depend on the carbide formed upon quenching. The type of carbide formed is dependent on quenching temperature. $\mathrm{M}_{23} \mathrm{C}_{6}$ carbides may form in this temperature range.

In the temperature range of 650 to $900^{\circ} \mathrm{C}$, intermetallic precipitates form at grain boundaries in Alloys C-276 and C-22 but not in Alloys C-4 and 625 for aging times up to $100 \mathrm{~h}$. The intermetallics increase the susceptibility of Alloys C-22 and C-276 to sensitization.

Low-temperature aging $\left(<600^{\circ} \mathrm{C}\right)$ causes various changes depending on the alloy. Long-range ordering occurs and carbide precipitates form in all of the alloys. The ordered precipitation has a significant effect on the mechanical and corrosion properties of the alloys. Intermetallic precipitation also occurs in Alloys C-22 and C-276.

In terms of phase stability, Alloy $\mathrm{C}-4$ is superior to Alloys C-22, C-276, and 625. Alloys C-22 and C-276 are susceptible to intermetallic and carbide precipitation. Alloy 625 is susceptible to carbide precipitation and microstructural ordering. Alloy $\mathrm{C}-4$ appears to be the most resistant to adverse microstructural changes.

Long-term aging of the $\mathrm{Ni}-\mathrm{Cr}$-Mo alloys should be studied at temperatures of $250^{\circ} \mathrm{C}$ and less. Investigations should (1) determine whether grain-boundary carbides and intermetallics form and whether longrange ordering of the bulk occurs, and (2) identify the effects on mechanical and corrosion properties of these alloys. 


\section{Stress Corrosion Cracking and Localized Corrosion in Chloride Environments}

This section reports on stress corrosion cracking (SCC) and localized corrosion (LC) in chloride solutions other than marine environments, which are presented in Sec. 4. The chloride environments considered are $\mathrm{MgCl}_{2}$ and numerous acid chloride solutions. Where possible, the data on SCC and LC in the Ni-CrMo alloys are compared with those of the other alloys.

\subsection{Introduction to SCC and LC}

SCC is a term used to describe failures in engineering materials that occur by environmentally induced crack propagation. The observed crack propagation is the result of the synergistic interaction of mechanical stress and corrosion reactions. LC includes pitting and crevice corrosion. Penetration rates at local sites of corrosion are far more serious threats to container life than rates due to general atmospheric and aqueous-phase corrosion.

SCC can result in the catastrophic failure of metals. Cracking can be either transgranular or intergranular, depending on the environmental and mechanical conditions. For SCC to occur, a susceptible material must have a minimum amount of stress in an aggressive environment. The stress necessary to cause SCC in a material is less than that necessary to fracture it in the absence of the aggressive environment. Residual stresses such as those from welding are often sufficient to cause SCC. Under certain circumstances, iron- and nickel-based corrosion-resistant alloys are susceptible to SCC in chloride environments, and copper-based alloys are susceptible to SCC in ammonia and nitrate environments.

Ionic and molecular species present in aqueous environments (water and moisture films) can serve as Fromoters, depolarizers, or inhibitors of LC and SCC in iron- and nickel-based corrosion-resistant alloys (Fontana and Greene 1978, Uhlig 1971). For example, $\mathrm{F}^{-}, \mathrm{Cl}^{-}$, and $\mathrm{Br}$ can induce localized breakdown of passive films, thereby initiating pit formation; such species are known as promoters.

Frequently, stress corrosion cracks initiate at pits. Anodic dissolution at the bases of pits and at crack tips can be enhanced by a number of depolarizers, including $\mathrm{O}_{2}, \mathrm{H}^{+}, \mathrm{Fe}^{3+}, \mathrm{Cu}^{2+}$, and $\mathrm{Hg}^{2+}$. The cathodic reduction of depolarizers on surfaces outside of crevices, pits, and cracks can galvanically couple with anodic dissolution and oxidation processes that occur inside pits. In contrast to promoters, anions such as $\mathrm{NO}_{3}{ }^{-}$and acetate
$\left(\mathrm{CH}_{3} \mathrm{COO}^{-}\right)$are known inhibitors of pitting and $\mathrm{SCC}$ in austenitic stainless steels. It is thought that these inhibitors compete with halide ions for adsorption sites on the metal oxide film and base metal. In alkaline media, $\mathrm{OH}^{-}, \mathrm{H}^{+}$, and $\mathrm{PO}_{4}{ }^{3-}$ can serve as promoter, depolarizer, and buffer, respectively.

The second factor required for SCC is mechanical stress. The stresses required are small, usually below the macroscopic yield stress, and they are tensile in nature. The stresses can be externally applied, but residual stresses are often sufficient to cause SCC failure. One frequent misconception is that SCC is the result of stress concentration at corrosion-generated surface flaws (as quantified by the stress intensity factor, $K$ ), and that when a critical value of stress concentration, $K_{\text {crit }}$, is reached, mechanical fracture results. Although stress concentration is necessary for $\mathrm{SCC}$, it is not necessary for it to exceed the critical value required to cause mechanical fracture of the materials in an inert environment $\left(K_{\mathrm{SCC}}<K_{\mathrm{crit}}\right.$.

\section{2 $\mathrm{SCC}$ in $\mathrm{MgCl}_{2}$ Solutions}

SCC screening tests of alloys are often performed in solutions of $\mathrm{MgCl}_{2}$. In fact, boiling $42 \% \mathrm{MgCl}_{2}$ is specified for SCC tests by ASTM Standard G-36 (ASTM 1987). These solutions are probably the most aggressive SCC agent for the 300-series stainless steels (Warren 1960) (see Fig. 16). Warren (1960) exposed U-bend specimens of 18-8 stainless steel to several chloride solutions, each having a different cation. The $\mathrm{Mg}^{2+}$ cation was the most aggressive of the cations tested, followed closely by $\mathrm{Fe}^{3+}$ and then $\mathrm{Ca}^{2+}$ and $\mathrm{Na}^{+}$. Low $\mathrm{pH}$ values also enhance the susceptibility of Type 304 stainless steel to SCC in solutions of $\mathrm{MgCl}_{2}$, but $\mathrm{pH}$ appears to have little effect on its susceptibility in $\mathrm{CaCl}_{2}$ solutions (Fig. 17).

High nickel contents in $\mathrm{Fe}-\mathrm{Cr}-\mathrm{Ni}-\mathrm{Mn}$ alloys are believed to increase the resistance of these a lloys to SCC. Figure 18 shows that $\mathrm{Fe}-\mathrm{Cr}(15-20 \mathrm{wt} \%)-\mathrm{N}$ i wires with nickel contents higher than 45 to $50 \mathrm{wt} \%$ c id not crack in boiling $42 \% \mathrm{MgCl}_{2}$ for times up to 30 cays. In addition to the nickel content of the specimens, , other metallurgical effects are influencing the SCC susceptibility of these specimens, as evidenced by two feitures of the data. First, some specimens with nickel contents below $45 \mathrm{wt} \%$ did not break in the solution after 30 days, and second, there was a rather large variation in breaking times for alloys with nickel contents below $45 \mathrm{wt} \%$. 


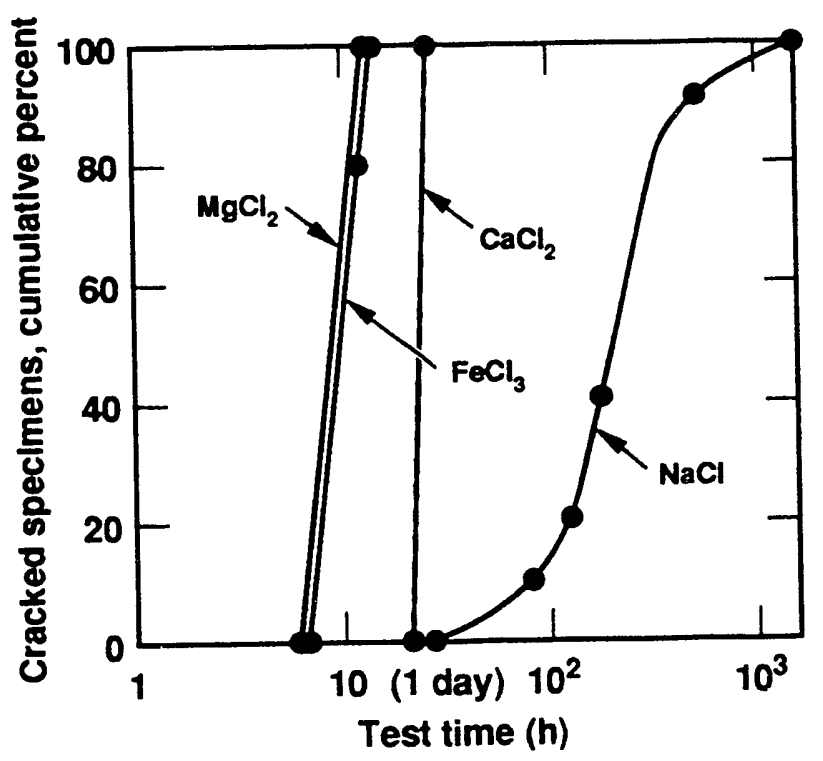

Figure 16. Effect of metallic cation on the timefor-cracking of Type 304 stainless steel U-bend specimens exposed at $100^{\circ} \mathrm{C}$ to water containing 100 ppm chloride (Warren 1960). Specimens were stressed to a maximum of $90 \%$ of the $0.2 \%$ offset yield stress (34 ksi). $\mathrm{Mg}^{2+}$ is the most aggressive cation.

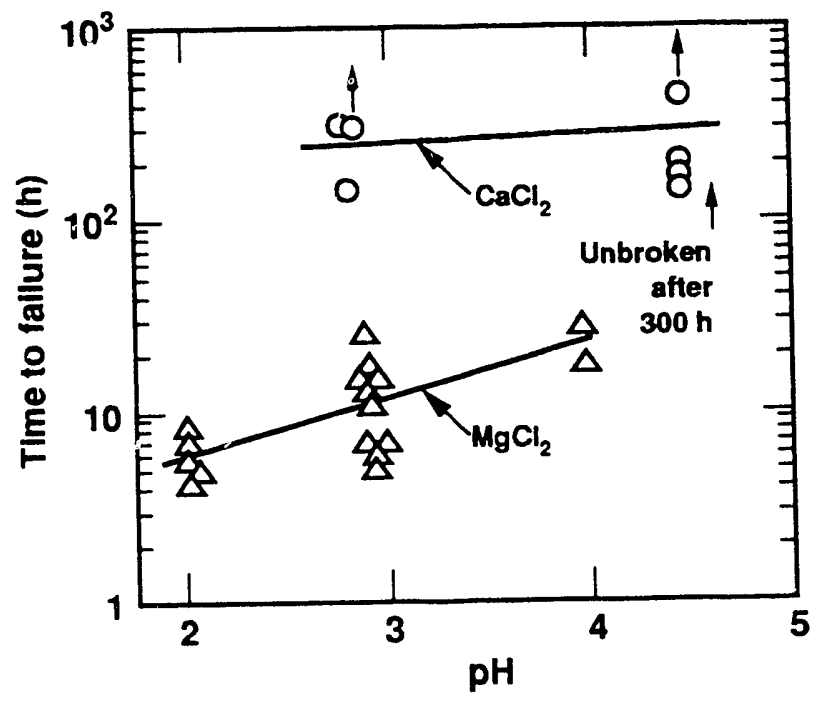

Figure 17. Effect of $\mathrm{pH}$ on the time-to-failure of Type 304 stainless steel at $\mathbf{5 0 , 0 0 0} \mathbf{p s i}$ in $\mathbf{M g C l}_{2}$ and $\mathrm{CaCl}$ solutions at $125^{\circ} \mathrm{C}$ (Warren 1960).

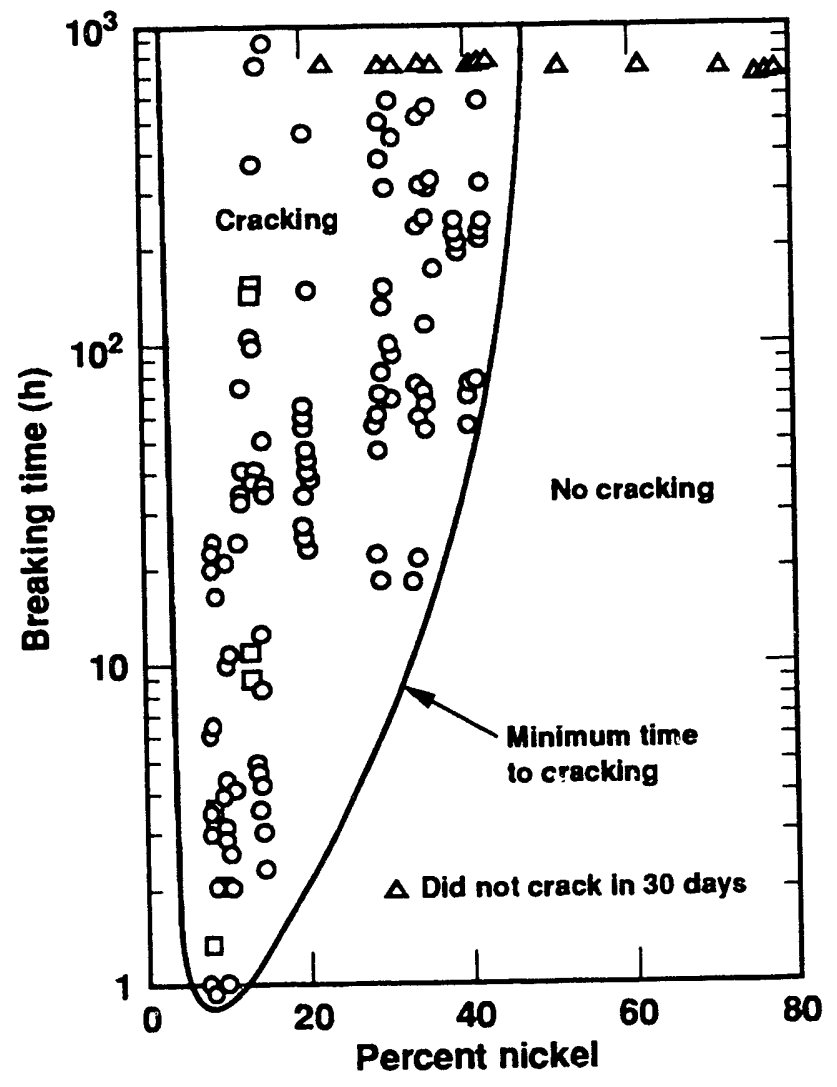

Figure 18. Effect of increasing the nickel content on the susceptibility of $\mathrm{Fe}-\mathrm{Cr}(15-20 \mathrm{wt} \%)$-Ni wires in boiling $42 \% \mathrm{MgCl}_{2}$ (Copson 1959). Testing was performed at 33 and $45 \mathrm{ksi}$ on annealed, partially hardened, and fully hardened wire. Testing stresses were all below the ultimate tensile stresses of the materials. For the annealed wire, stress levels varied from 0.68 to 1.81 times the yield stresses. For the partially hardened wire, stress levels varied from 0.22 to 0.63 times the yield stresses. For the fully hardened wire, stress levels varied from 0.14 to 0.21 times the yield stresses.

The enhanced resistance of $\mathrm{Ni}-\mathrm{Cr}$-Mo alloys to SCC in chloride environments is illustrated by tests in boiling $45 \% \mathrm{MgCl}_{2}\left(154^{\circ} \mathrm{C}\right.$ ) (Table 10$)$. Specimens of Types 304 and 316 stainless steels (nickel content of $8 \mathrm{wt} \%$ ) both fractured in less than $72 \mathrm{~h}$. Alloys 600 (79.5\% nickel) and C ( $56 \%$ nickel) did not fracture after testing up to $456 \mathrm{~h}$. Cracks in the stainless steels were transgranular. The high-nickel alloys did not show evidence of surface pitting.

Another study of SCC testing in solutions of $45 \%$ $\mathrm{MgCl}_{2}\left(154^{\circ} \mathrm{C}\right)$ confirms the superior SCC resistance 
Table 10. The behavior of various stressed specimens tested in boiling $\mathrm{MgCl}_{2}$ solutions at $154^{\circ} \mathrm{C}$ (Scheil 1948 ).

\begin{tabular}{|c|c|c|c|c|c|c|c|c|}
\hline \multirow[b]{2}{*}{ Alloy } & \multicolumn{2}{|c|}{ Heat treatment } & \multirow{2}{*}{$\begin{array}{c}\text { Surface } \\
\text { finish }\end{array}$} & \multirow{2}{*}{$\begin{array}{l}\text { Applied } \\
\text { stress } \\
\text { (psi) }\end{array}$} & \multirow{2}{*}{$\begin{array}{l}\text { Time to } \\
\text { first cracks } \\
\text { (h) }\end{array}$} & \multirow{2}{*}{$\begin{array}{l}\text { Time to } \\
\text { fracture } \\
\text { (h) }\end{array}$} & \multirow{2}{*}{$\begin{array}{c}\text { No } \\
\text { cracking } \\
\text { (h) }\end{array}$} & \multirow[b]{2}{*}{ Features } \\
\hline & ${ }^{\circ} \mathrm{C}$ & $\begin{array}{l}\text { Time } \\
\text { (h) }\end{array}$ & & & & & & \\
\hline Type 304 & 650 & 1 & $\begin{array}{l}\text { Original } \\
\text { cold finish }\end{array}$ & $\begin{array}{l}\text { Greater than } \\
\text { the yield point }\end{array}$ & - & 8 & - & Transgranular cracks \\
\hline Type 304 & None & & $\begin{array}{l}\text { Original } \\
\text { cold finish }\end{array}$ & $\begin{array}{l}\text { Greater than } \\
\text { the yield point }\end{array}$ & - & 17 & - & Transgranular cracks \\
\hline Type 316 & 870 & 1600 & Polished & 40,000 & 7 & $49-72$ & - & Transgranular cracks \\
\hline $600^{2}$ & 595 & 2 & Polished & 20,000 & - & - & 456 & No surface pits \\
\hline $600^{2}$ & 595 & 2 & Polished & $\begin{array}{l}\text { Greater than } \\
\text { the yield point }\end{array}$ & - & - & 408 & No surface pits \\
\hline $\mathbf{C}^{\mathbf{b}}$ & 595 & 2 & Polished & 30,000 & - & - & 456 & No surface pits \\
\hline $\mathbf{C}^{b}$ & 595 & 2 & Polished & $\begin{array}{l}\text { Greater than } \\
\text { the yield point }\end{array}$ & - & - & 120 & No surface pits \\
\hline
\end{tabular}

a Alloy 600 (13Cr-6.5Fe-79.5Ni); the same specimen was used. It was first polished and stressed to $20,000 \mathrm{psi}$, tested for $456 \mathrm{~h}$, then stressed beyond the yield point and tested for $408 \mathrm{~h}$. (Alloy 600 is referred to as Inconel in the original text.)

b Alloy C (14Cr-17Mo-6Fe-56Ni); the same specimen was used. It was first polished and stressed to 30,000 psi, tested for $456 \mathrm{~h}$, then stressed beyond the yield point and tested for $120 \mathrm{~h}$.

of the Ni-Cr-Mo alloys (Haynes 1987a) (Table 11). Alloys 625, C-276, and C-22 did not crack in this solution after $1000 \mathrm{~h}$. However, Alloy 825 cracked in $46 \mathrm{~h}$, and Types 304 and $316 \mathrm{~L}$ stainless steels both cracked in 1 to $2 \mathrm{~h}$.

\subsection{SCC and L.C in Other Chloride Solutions}

The Ni-Cr-Mo alloys also have superior resistance to SCC in environments containing sulfur and other chloride compounds (Table 12). Lichti et al. (1984) exposed U-bend specimens of various alloys heated to $100^{\circ} \mathrm{C}$ to a drip solution containing up to $70 \mathrm{ppm} \mathrm{Cl}^{-}$ and having a pH of 5 to 6 and a temperature of 10 to $20^{\circ} \mathrm{C}$. Types 304 and $316 \mathrm{~L}$ stainless steels were susceptible to both cracking and pitting. However, the molybderum-containing Type 316L stainless steel was less susceptible to pitting than Type 304 stainless steel. Cracking did not occur in the high-nickel Alloy 825 , but it was susceptible to pitting. Neither pitting nor cracking occurred in the Ni-Cr-Mo materials Alloys 625 and C-276. Also, pure titanium was immune to pitting and cracking in this environment.

Asphahani (1980b) has studied the chloride SCC of several austenitic materials in numerous acidic $\mathrm{NaCl}$ solutions (see Tables 13 through 19). Chloride SCC of
Table 11. SCC in $45 \% \mathrm{MgCl}_{2}$ at $154^{\circ} \mathrm{C}$ (Haynes 1987a). Stress levels were not givan.

\begin{tabular}{lc}
\hline \multicolumn{1}{c}{ Alloy } & $\begin{array}{c}\text { Time to crack } \\
\text { (h) }\end{array}$ \\
\hline Type 304 stainless steel & $1-2$ \\
Type 316L stairless steel & $1-2$ \\
825 & 46 \\
625 & No cracks (1000) \\
C-276 & No cracks (1000) \\
C-22 & No cracks (1000) \\
\hline
\end{tabular}

Types $304,304 \mathrm{~L}, 316$, and $316 \mathrm{~L}$ stainless steels was observed in dilute $\mathrm{NaCl}$ solutions $(0.8$ to $4 \%)$ containing either $\mathrm{H}_{3} \mathrm{PO}_{4}(0.2$ to $1 \%)$ or $\mathrm{CH}_{3} \mathrm{COOH}(0.5 \%)$. SCC of these austenitic stainless steels could be induced by 10 ciays of exposure to a solution containing $0.8 \%$ $\mathrm{NaCl}$ and $0.2 \% \mathrm{H}_{3} \mathrm{PO}_{4}$ at $141^{\circ} \mathrm{C}$. Pitting and crevice corrosion were predominant in solutions containing acetic acid.

In sharp contrast to the 300-series stainless steels, the austenitic stainless alloys with a higher nickel content (Alloy 20Cb-3, Alloy 825, and Alloy 20Mod) are very resistant to chloride stress cracking 
Table 12. Results of tests for pitting corrosion and SCC in heated U-bends (Lichti et al. 1984). Specimens were heated to about 80 to $120^{\circ} \mathrm{C}$, and the solution was slightly acidic and contained chloride. ${ }^{2}$ The U-bend specimens were made to ASTM G30-70 for material thicknesses of 1.5 to $1.7 \mathrm{~mm}$.

\begin{tabular}{lcll}
\hline Alloy & $\begin{array}{c}\text { Exposure } \\
\text { time } \\
\text { (days) }\end{array}$ & $\begin{array}{c}\text { Maximum } \\
\text { pit depth } \\
\text { (mm) }\end{array}$ & Cracking \\
\hline Type 304 & $21^{\mathrm{b}}$ & $290+$ & Branched \\
& 42 & $140+$ & cracking in \\
& 56 & $216+$ & all specimens \\
& 105 & $375+$ & Branched \\
Type 316L & $21^{\mathrm{b}}$ & $161+$ & cracking in \\
& 42 & $123+$ & all specimens \\
825 & 63 & $145+$ & Not detected \\
& $7^{\mathrm{b}}$ & 147 & Not detected \\
& 63 & 137 & Not detected \\
625 & 105 & 208 & Not detected \\
C-276 & 63 & Not detected & Notect \\
Ti-Gr4 & 63 & Not detected & Not detected \\
\hline
\end{tabular}

2 Characterization of fluids dripped onto U-bends: $\mathrm{CO}_{2}, 200$ to $1400 \mathrm{ppm} ; \mathrm{HCO}_{3}{ }^{-}, 50$ to $200 \mathrm{ppm} ; \mathrm{H}_{2} \mathrm{~S}, 10$ to $75 \mathrm{ppm} ; \mathrm{NH}_{4}{ }^{+}$, 30 to $40 \mathrm{ppm}$; Fe (total), $0.2 \mathrm{ppm} ; \mathrm{SO}_{4}{ }^{2-}, 1$ to $20 \mathrm{ppm} ; \mathrm{SiO}_{2},<1$ ppm; $\mathrm{Cr}, 30$ to $70 \mathrm{ppm}$ ( $30 \mathrm{ppm}$ added as $\mathrm{NaCl}$ ); $\mathrm{pH}=5.0$ to 6.0; and $T=10$ to $20^{\circ} \mathrm{C}$.

b Initial trials with fewer specimens were assumed to have been at a higher temperature.

(Asphahani 1980b). However, some pitting and crevice corrosion were observed in these materials with the exception of Alloy 20-Mod. Alloys G and C-276, however, show excellent resistance to chloride stress cracking and to localized corrosive attack.

The SCC tests were conducted on U-bend specimens about $133 \times 13 \times 3 \mathrm{~mm}$ in size (Asphahani 1980b). Each specimen was deformed around a $25-\mathrm{mm}$ mandrel and then further stressed by straining its ends (tightening a nut and bolt) to a final span of $12 \mathrm{~mm}$. The imposed stress depended on the yield stress of the material, and no effort was made to calculate the exact value of the applied stress. Samples were exposed to the acidic $\mathrm{NaCl}$ solutions at $141^{\circ} \mathrm{C}$ in sealed Alloy C-276 autoclaves. For the nominal compositions of the alloys tested, see Tables 3 and 4 in Sec. 1 .

In acid chloride solutions of phosphoric acid, the $\mathrm{Ni}-\mathrm{Cr}$-Mo alloys exhibited superior resistance to SCC. After a 1-month exposure to a solution containing $4 \%$
Table 13. $\mathrm{LC}$ and SCC in austenitic materials exposed for 1 month to a solution of $4 \% \mathrm{NaCl}+1 \%$ $\mathrm{H}_{3} \mathrm{PO}_{4}$ at $141^{\circ} \mathrm{C}$ (Asphahani et al. 1980a). Two U-bend specimens of each alloy were used in these tests as well as in the tests reported in Tables 14 through 19.

\begin{tabular}{|c|c|c|c|}
\hline Alloy & $\begin{array}{c}\text { Corrosion } \\
\text { rate } \\
(\mathrm{mm} / \mathbf{y r})\end{array}$ & $\mathbf{L C}$ & SCC \\
\hline 304 & 0.15 & Crevice corrosion & Yes \\
\hline $304 \mathrm{~L}$ & 0.13 & Crevice corrosion & Yes \\
\hline 316 & 0.11 & Crevice corrosion & Yes \\
\hline $316 \mathrm{~L}$ & 0.04 & Slight attack & Yes \\
\hline $20 \mathrm{Cb}-3$ & 0.07 & $\begin{array}{l}\text { Pitting, severe } \\
\text { crevice corrosion }\end{array}$ & No \\
\hline 825 & $<0.01$ & No attack & No \\
\hline 20-Mod & $<0.01$ & No attack & No \\
\hline $\mathbf{G}$ & $<0.01$ & No attack & No \\
\hline C-276 & $<0.01$ & No attack & No \\
\hline
\end{tabular}

2 The U-bend specimens $(133 \times 13 \times 3 \mathrm{~mm})$ were deformed around a $25 \cdot \mathrm{mm}$ mandrel. The specimens' ends were maintained in a parallel position with a bolt and a nut made of Alloy C-276. Tenon inserts were used to insulate the bolt/nut from the specimen. The specimen was further stressed by straining its ends (tightening the nut) to a final span of $12 \mathrm{~mm}$. The imposed stress depended on the yieid stress of the material, and no effort was made to calculate the value of the applied stress.

$\mathrm{NaCl}$ and $1 \% \mathrm{H}_{3} \mathrm{PO}_{4}$ at $141^{\circ} \mathrm{C}$ (Table 13), branching, transgranular stress corrosion cracking (TGSCC) was observed in the 300-series specimens (Types 304, 304L, 316, and 316L stainless steels). Furthermore, severe crevice corrosion was observed under the nut and the head of the bolt used for stressing these samples. Alloy $20 \mathrm{Cb}-3$ suffered severe pitting and crevice corrosion but no SCC. Alloy 825 showed only slight crevice corrosion and was completely resistant to SCC. Alloys 20-Mod, $\mathrm{G}$, and C-276 all demonstrated outstanding resistance to both localized attack and SCC. In the same solution at $82^{\circ} \mathrm{C}$, similar results were obtained: Types 304 and 304L showed cracking, and Alloys 20-Mod, G, and C-276 did not (Table 19). Similar results were observed in more dilute solutions of $\mathrm{NaCl}$ and $\mathrm{H}_{3} \mathrm{PO}_{4}$ at $141^{\circ} \mathrm{C}$, except that the attack of Alloy 825 was slightly worse (Table 14).

Tests were also conducted in a chloride solution of acetic acid $\left(0.8 \% \mathrm{NaCl}+0.5 \% \mathrm{CH}_{3} \mathrm{COOH}\right)$ (Table 15$)$. Again, branching TGSCC was observed for the 
Table 14. $\mathrm{LC}$ and $\mathrm{SCC}$ in austenitic materials exposed for 1 month to $0.8 \% \mathrm{NaCl}+0.2 \% \mathrm{H}_{3} \mathrm{PO}_{4}$ at $141^{\circ} \mathrm{C}$ (Asphahani et al. 1980a). U-bend specimens are described in Table 13.

\begin{tabular}{|c|c|c|c|}
\hline Alloy & $\begin{array}{c}\text { Corrosion } \\
\text { rate } \\
(\mathrm{mm} / \mathrm{yr})\end{array}$ & $\mathbf{L C}$ & SCC \\
\hline $304^{a}$ & 0.14 & Crevice corrosion & Yes \\
\hline $304 L^{2}$ & 0.03 & Crevice corrosion & Yes \\
\hline $316^{2}$ & 0.02 & Crevice corrosion & Yes \\
\hline $316 L^{2}$ & 0.01 & Slight attack & Yes \\
\hline $20 \mathrm{Cb}-3$ & 0.07 & $\begin{array}{l}\text { Pitting, crevice } \\
\text { corrosion }\end{array}$ & No \\
\hline 825 & 0.03 & $\begin{array}{l}\text { Pitting, crevice } \\
\text { corrosion }\end{array}$ & No \\
\hline 20-Mod & $<0.01$ & No attack & No \\
\hline G & $<0.01$ & No attack & No \\
\hline C-276 & $<0.01$ & No attack & No \\
\hline
\end{tabular}

2 Specimens were removed after 10 days.

Table 15. $\mathrm{LC}$ and SCC in austenitic materials exposed for 1 month to $0.8 \% \mathrm{NaCl}+0.5 \%$ $\mathrm{CH}_{3} \mathrm{COOH}$ at $141^{\circ} \mathrm{C}$ (Asphahani et al. 1980a). $\mathrm{U}$-bend specimens are described in Table 13.

\begin{tabular}{|c|c|c|c|}
\hline Alloy & $\begin{array}{c}\text { Corrosion } \\
\text { rate } \\
(\mathrm{mm} / \mathrm{yr})\end{array}$ & $\mathbf{L C}$ & SCC \\
\hline 304 & 0.03 & Severe pitting & Yes \\
\hline $304 \mathrm{~L}$ & 0.02 & Severe pitting & Yes \\
\hline 316 & 0.01 & Severe pitting & Yes \\
\hline $316 \mathrm{~L}$ & $<0.01$ & Pitting & Yes $^{\mathrm{a}}$ \\
\hline $20 \mathrm{Cb}-3$ & $<0.01$ & No attack & No \\
\hline 825 & $<0.01$ & No attack & No \\
\hline 20-Mod & $<0.01$ & No attack & No \\
\hline $\mathbf{G}$ & $<0.01$ & No attack & No \\
\hline$C-276$ & $<0.01$ & No attack & No \\
\hline
\end{tabular}

One specimen out of two cracked.
Table 16. $\mathrm{LC}$ and $\mathrm{SCC}$ in austenitic materials exposed to $0.8 \% \mathrm{NaCl}+\mathrm{HCl}(\mathrm{pH}=2.2)$ at $141^{\circ} \mathrm{C}$ (Asphahani et al. 1980a). U-bend specimens are described in Table 13.

\begin{tabular}{lcc}
\hline Alloy & 10-day exposure & 30-day exposure \\
\hline 304 & No cracking & Cracking \\
$304 \mathrm{~L}$ & No crackingb & Cracking \\
316 & No cracking & Cracking \\
$316 \mathrm{~L}$ & No cracking & Cracking \\
$20 \mathrm{Cb}-3$ & No cracking & No cracking \\
825 & No cracking & No cracking \\
$20-\mathrm{Mod}$ & No cracking & No cracking \\
G & No cracking & No cracking \\
C-276 & No cracking & No cracking \\
\hline
\end{tabular}

- All specimens with no cracking after the 10-day exposure were tested for an additional 20 days. The container developed a leak at the seal and the test solution evaporated some time during the testing period. The temperature of the container was maintained at $141^{\circ} \mathrm{C}$.

b General dissolution, uniform thinning.

Table 17. $L C$ and SCC in austenitic materials exposed for one month to $2 \% \mathrm{NaCl}$ at $141^{\circ} \mathrm{C}$ (Asphahani et al. 1980a). U-bend specimens are described in Table 13.

\begin{tabular}{|c|c|c|c|}
\hline Alloy & $\begin{array}{c}\text { Corrosion } \\
\text { rate } \\
(\mathbf{m m} / \mathbf{y r})\end{array}$ & LC & $\mathrm{SCC}$ \\
\hline 304 & $0.02^{2}$ & Pitting & No \\
\hline $304 \mathrm{~L}$ & $0.08^{\mathrm{a}}$ & Pitting & No \\
\hline $20 \mathrm{Mod}$ & $<0.01$ & No attack & No \\
\hline G & $<0.01$ & No attack & No \\
\hline C-276 & $<0.01$ & No attack & No \\
\hline
\end{tabular}

2 Specimens suffered pitting attack within the first 10 days of exposure.

300-series alloys. Severe pitting and crevice corrosion of the specimens were also observed. The results of this series of tests indicated that SCC of Types 304, $304 \mathrm{~L}, 316$, and $316 \mathrm{~L}$ stainless steels was not limited to the chloride solutions containing $\mathrm{H}_{3} \mathrm{PO}_{4}$. Again, the higher-nickel alloys, such as Alloys 825 and C-276, did not suffer LC or SCC. 
Table 18. LC and SCC tests of austenitic materials exposed for one month to boiling $2 \% \mathrm{H}_{3} \mathrm{PO}_{4}$ at $102^{\circ} \mathrm{C}$ (Asphahani et al. 1980a). U-bend specimens are described in Table 13.

\begin{tabular}{|c|c|c|c|}
\hline Alloy & $\begin{array}{c}\text { Corrosion } \\
\text { rate } \\
(\mathbf{m m} / \mathbf{y r})\end{array}$ & LC & SCC \\
\hline 304 & $<0.01$ & No attack & No \\
\hline 304L & $<0.01$ & No attack & No \\
\hline 20-Mod & $<0.01$ & No attack & No \\
\hline G & $<0.01$ & No attack & No \\
\hline C.276 & $<0.01$ & No attack & No \\
\hline
\end{tabular}

Table 19. LC and SCC tests of austenitic materials exposed for one month to $4 \% \mathrm{NaCl}+1 \% \mathrm{H}_{3} \mathrm{PO}_{4}$ (pH about 1.7) (Asphahani et al. 1980a). U-bend specimens are described in Table 13.

\begin{tabular}{lll}
\hline Alloy & \multicolumn{1}{c}{$82^{\circ} \mathrm{C}$} & \multicolumn{1}{c}{$141^{\circ} \mathrm{C}$} \\
\hline 304 & Cracking & Cracking \\
$304 \mathrm{~L}$ & Cracking & Cracking \\
20-Mod & No cracking & No cracking \\
G & No cracking & No cracking \\
C-276 & No cracking & No cracking \\
\hline
\end{tabular}

The alloys were also tested in a solution of $0.8 \mathrm{wt} \%$ $\mathrm{NaCl}$ and $\mathrm{HCl}(\mathrm{pH}=2.2)$ at $141^{\circ} \mathrm{C}$ (Table 16). SCC was observed in the 300 -series stainless steels after 30 days of exposure; no SCC was observed in Alloy 825 or in Alloy C-276 and the other alloys with a high nickel content. Alloy 825 did exhibit general dissolution, which caused uniform thinning of the specimen.

SCC tests were also performed in both a $2 \% \mathrm{NaCl}$ solution (Table 17) and boiling $2 \% \mathrm{H}_{3} \mathrm{PO}_{4}$ (Table 18). In the boiling acid, no LC or SCC was observed for any of the alloys tested. In the salt solution, none of the alloys exhibited SCC, but Types 304 and 304L stainless steels did suffer pitting.

\subsection{Crevice Corrosion}

Crevice corrosion has the potential of causing catastrophic failure of materials and is therefore a major concern in material selection. It can occur because of poor equipment design or under deposits that form on the material surfaces. Differential aeration of the fluid in contact with the material is believed to cause galvanic corrosion between different regions of the material.

Localized forms of corrosive attack (pits, crevices, and "underdeposit" corrosion) are usually induced on stainless steels and nickel-based alloys by chloride ions, and they frequently occur under oxidizing conditions. The addition of chromium and molybdenum (and also tungsten to some extent) appears effective in enhancing resistance to LC (pitting/crevice corrosion) in oxidizing chloride solutions. The chromium addition improves corrosion resistance in oxidizing environments.

Several studies compared the susceptibilities of various alloys to crevice corrosion in well characterized solutions. These studies use similar crevices for all of the materials to permit comparisons among the materials. In addition to the studies of crevice corrosion discussed in this section, susceptibilities to crevice corrosion have been documented in marine environments (see Sec. 4).

Jackson and van Rooyen (1972) have studied the susceptibility of Type 316 stainless steel and Alloys 825,625 , and $\mathrm{C}$ to crevice corrosion in various chloride solutions at room temperature and $50^{\circ} \mathrm{C}$ (Table 20). In each of the solutions tested, the performance of Alloys 625 and $C$ was vastly superior to that of both Type 316 stainless steel and Alloy 825 . Alloy 825 generally performed much better than Type 316 stainless steel except in an acidic $\mathrm{FeCl}_{3}$ solution at room temperature.

Neither Alloy 625 nor Alloy C showed evidence of local attack; only general corrosion was observed. Alloy 625 had generally lower corrosion rates. Depending on the solution and temperature, the average penetration in Alloy 825 was larger than that in Alloy 625 and Alloy C by factors of 1600 to 90,000 .

Jackson and van Rooyen also tested Alloys 625 and $C$ with much smaller crevices (about $0.075 \mathrm{~mm}$ ) in $\mathrm{FeCl}_{3}$ at $50^{\circ} \mathrm{C}$ for $72 \mathrm{~h}$. Crevice corrosion in this instance was observed on both alloys. The average penetration in the attacked area of Alloy C $(5200 \mu \mathrm{m} / \mathrm{yr})$ was about a factor of 2 less than in Alloy 625 (9500 $\mu \mathrm{m} / \mathrm{yr}$ ). It is interesting that some of the specimens of Alloy C did not suffer crevice corrosion; only general dissolution was observed at a rate of about $30 \mu \mathrm{m} / \mathrm{yr}$.

Another study (Haynes 1987a) has also reported susceptibility of various alloys to crevice corrosion in a ferric chloride $\left(\mathrm{FeCl}_{3}\right)$ solution at room temperature (Table 21). Twenty-four crevices of each material were tested, and the number of crevices attacked was observed. No crevice attack was observed for Alloys C-276 and C-22, while $46 \%$ of the crevices were attacked in Alloy 625 and 100\% in Alloy 825. The attack 
Table 20. Crevice corrosion results in several chloride solutions with a "wide" crevice (0.25 mm spacer) (Jackson and van Rooyen 1972). Exposure time was 72 h.

\begin{tabular}{lrrrr}
\hline \multicolumn{1}{c}{ Test } & \multicolumn{4}{c}{ Average penetration in attacked area $(\mu \mathrm{m} / \mathrm{yr})$} \\
\cline { 2 - 5 } & Type 316 & Alloy 825 & Alloy $625^{\mathbf{2}}$ & \multicolumn{1}{c}{ Alloy $\mathrm{C}^{\mathbf{2}}$} \\
\hline $5 \% \mathrm{FeCl}_{3}, 50^{\circ} \mathrm{C}$ & 410,000 & 200,000 & 40 & 20 \\
$5 \% \mathrm{CuCl}_{2}, 50^{\circ} \mathrm{C}$ & $23,950,000$ & 200,000 & 3 & 10 \\
$5 \% \mathrm{NaOCl}^{\circ}, 50^{\circ} \mathrm{C}$ & 73,000 & 46,000 & 3 & 6 \\
$5 \% \mathrm{FeCl}_{3}+5 \% \mathrm{HCl}$, & 250,000 & 360,000 & 4 & 20 \\
room temperature & & & & \\
$5 \% \mathrm{FeCl}_{3}$, room & 320,000 & 32,000 & 2 & 20 \\
temperature & & & & \\
$5 \% \mathrm{FeCl}_{3}, 50^{\circ} \mathrm{C}$ & - & - & $9500^{\mathrm{b}}$ & $5200^{\mathrm{b}}$ \\
\hline
\end{tabular}

- General corrosion only; no visible local attack; materials were all commercial-mill annealed as received.

b "Tight crevices"; about a $0.075-\mathrm{mm}$ space.

Table 21. Crevice-corrosion data from tests conducted in $10 \% \mathrm{FeCl}_{3}$ at room temperature for 10 days (Haynes 1987a).

\begin{tabular}{lcc}
\hline \multicolumn{1}{c}{ Alloy } & $\begin{array}{c}\text { Number of } \\
\text { attacked crevices } \\
(24 \text { maximum })\end{array}$ & $\begin{array}{c}\text { Maximum depth } \\
\text { of penetration } \\
(\mu \mathrm{m})\end{array}$ \\
\hline C-276 & 0 & 0 \\
C-22 & 0 & 0 \\
625 & 11 & 76 \\
Type 317LM & 20 & 305 \\
stainless steel & & \\
904L & 23 & 483 \\
20 Cb-3 & 24 & 1930 \\
825 & 24 & 3175 \\
\hline
\end{tabular}

was also much more severe in Alloy 825 than in Alloy 625. Penetration depths were about a factor of 40 greater in Alloy 825 than in Alloy 625.

The superior resistance of Alloys C-276 and C-22 to crevice corrosion is retained even at elevated temperatures. Data on average corrosion rate for crevice corrosion specimens of several alloys are shown in Table 22 for three temperatures. Average corrosion rates were calculated even though most corrosion occurred under the crevice. There is an increase in average
Table 22. Crevice corrosion data from tests conducted in $10 \% \mathrm{FeCl}_{3}$ (Haynes 1987a).

\begin{tabular}{lrrr}
\hline & \multicolumn{3}{c}{ Average corrosion rate $(\mu \mathrm{m} / \mathrm{yr})$} \\
\cline { 2 - 4 } \multicolumn{1}{c}{ Alloy } & \multicolumn{1}{c}{$25^{\circ} \mathrm{C}$} & \multicolumn{1}{c}{$50^{\circ} \mathrm{C}$} & \multicolumn{1}{c}{$\mathbf{7 5}^{\circ} \mathrm{C}$} \\
\hline C-276 & 5.1 & 5.1 & 35.6 \\
C-22 & 2.5 & 2.5 & 12.7 \\
C-4 & 7.6 & 12.7 & 508 \\
255 & 10.2 & 20,600 & 16,840 \\
625 & 38.1 & 3,150 & 12,950 \\
20 Cb-3 & 5,210 & 9,650 & 17,800 \\
Type 316L & 7,925 & 11,700 & 19,810 \\
stainless steel & & & \\
825 & 18,540 & 17,960 & 17,270 \\
\hline
\end{tabular}

The average corrosion rate on duplicate samples is given even though most corrosion occurred under the crevice. Tests were conducted for $100 \mathrm{~h}$ with a grooved block.

corrosion for Alloys C-276 and C-22 as a function of temperature, but it remains small in comparison with the rates for the other alloys. The corrosion rate of Alloy 625 was about 7 times larger than that of Alloy C-276 at $25^{\circ} \mathrm{C}$ and increased to more than 350 times at $75^{\circ} \mathrm{C}$. The corrosion rate of Alloy 825 decreased slightly with increasing temperature, but it remained significantly higher (almost 500 times) than that of Alloy C-276. 
Table 23. Corrosion rates in $\mathrm{FeCl}_{3}(\mu \mathrm{m} / \mathrm{y})$. Rates are averages of two tests. The localized corrosive attacks are in the form of pits and crevice corrosion (Asphahani et al. 1980b).

\begin{tabular}{|c|c|c|c|c|}
\hline \multirow[b]{2}{*}{ Alloy } & \multicolumn{2}{|c|}{$10 \% \mathrm{FeCl}_{3} ;$ artificial crevices } & \multicolumn{2}{|c|}{$\begin{array}{c}\text { Smooth specimens (24-h period) } \\
7 \text { vol\% } \mathrm{H}_{2} \mathrm{SO}_{4}+3 \mathrm{vol} \% \mathrm{HCl} \\
+1 \% \mathrm{FeCl}_{3}+1 \% \mathrm{CuCl}_{2}\end{array}$} \\
\hline & $25^{\circ} \mathrm{C}, 240 \mathrm{~h}$ & $50^{\circ} \mathrm{C}, 100 \mathrm{~h}$ & $25^{\circ} \mathrm{C}$ & $102^{\circ} \mathrm{C}$ \\
\hline $\mathbf{G}$ & 406 & 584 (crevice) & 10 & 44,650 (pitting) \\
\hline 625 & 38.1 & 3,150 (crevice) & 7.62 & 48,060 (pitting) \\
\hline C-276 & 5.08 & 5.08 & 7.62 & 610 \\
\hline 20-Mod & 106.7 & 2,390 (crevice) & 58.4 & 58,880 (pitting) \\
\hline $\begin{array}{l}\text { Type 316L } \\
\text { stainless steel }\end{array}$ & 7,925 (crevice) & 11,680 (crevice) & 2,565 (pitting) & 99,290 (pitting) \\
\hline
\end{tabular}

Table 23 shows data for crevice corrosion testing in $\mathrm{FeCl}_{3}$ at 25 and $50^{\circ} \mathrm{C}$ (Asphahani 1987b). The data show that Alloy C-276 was not crevice-attacked at either 25 or $50^{\circ} \mathrm{C}$. Alloy 625 was not crevice-attacked at $25^{\circ} \mathrm{C}$ but was severely crevice-attacked at $50^{\circ} \mathrm{C}$. Type 316 stainless steel suffered severe crevice corrosion at both temperatures.

\subsection{Effect of Temperature on Pitting}

Alloy C-276 has superior piting resistance compared with Type 316L stainless steel and Alloys G, 625, and 20-Mod at elevated temperatures (Table 23)

(Asphahani 1980b). Smooth st ecimens of these alloys were tested for $24 \mathrm{~h}$ in a solv'son of $7 \mathrm{vol} \% \mathrm{H}_{2} \mathrm{SO}_{4}+$ $3 \mathrm{vol} \% \mathrm{HCl}+1 \mathrm{wt} \% \mathrm{CuCl}_{2}+1 \mathrm{wt} \% \mathrm{FeCl}_{3}$ at 25 and $102^{\circ} \mathrm{C}$. At $25^{\circ} \mathrm{C}$, no pitting was observed on Alloys 625 and $C-276$, and average corrosion rates were the same. At $102^{\circ} \mathrm{C}$, Alloy C-276 did not pit, but Alloy 625 did severely pit. The average corrosion rate of Alloy 625 was about 80 times greater than that of Alloy C-276. Figure 19 shows photographs of the specimens after testing (see the case of $0 \%$ cold work).

\subsection{Effect of Cold Work on Pitting}

At high temperatures $\left(>70^{\circ} \mathrm{C}\right)$, cold-worked Alloy $\mathrm{C}-276$ has much better resistance to pitting than does cold-worked Alloy 625. Specimens of Alloys 625 and C-276 that underwent $0,10,30$, and $50 \%$ cold work were immersed for $24 \mathrm{~h}$ in solutions of $7 \mathrm{vol} \% \mathrm{H}_{2} \mathrm{SO}_{4}$ $+3 \mathrm{vol} \% \mathrm{HCl}+1 \mathrm{wt} \% \mathrm{CuCl}_{2}+1 \mathrm{wt} \% \mathrm{FeCl}_{3}$ at various temperatures (Asphahani 1980b). At $25^{\circ} \mathrm{C}$, no pitting was observed on either alloy. At $70^{\circ} \mathrm{C}$, no pitting was observed on any Alloy C-276 specimens, but pitting was observed on Alloy 625 specimens with $\geq 10 \%$ cold work. At $102^{\circ} \mathrm{C}$, no pitting was observed on any Alloy C-276 specimens, but pitting was observed on all specimens of Alloy 625 regardless of the amount of cold work. Photographs of the specimens are shown in Fig. 19.

\subsection{Critical Crevice Corrosion and Pitting Temperatures}

The relative susceptibility of various materials to crevice corrosion and pitting in a particular solution can be indicated by critical crevice corrosion and critical pitting temperatures, respectively. The critical temperatures are defined as the temperatures above which the phenomena will occur.

Numerous nickel alloys were tested for pitting in a 6-wt $\% \mathrm{FeCl}_{3}$ solution for 24 -h periods (Table 24) (Hibner 1986). Of the alloys tested, Alloys C-22 and C-276 performed best, having critical pitting temperatures of 70 and $62.5^{\circ} \mathrm{C}$, respectively. Alloys 625 and $\mathrm{C}-4$ both had a critical pitting temperature of $37.5^{\circ} \mathrm{C}$, which was $25^{\circ} \mathrm{C}$ less than that of Alloy C-276. Alloy 825 was the most susceptible to pitting of the materials tested. It had a critical pitting temperature of only $0^{\circ} \mathrm{C}$.

In an oxidizing solution of $\mathrm{NaCl}-\mathrm{HCl}(\mathrm{pH}=2$ and $24,300 \mathrm{ppm} \mathrm{Cl}^{-}$), Alloys $\mathrm{C}-22$ and $\mathrm{C}-276$ again showed superior resistance to crevice corrosion and pitting, as indicated by their critical temperatures (Table 25) (Haynes 1987b). Alloy C-22 had the highest critical 


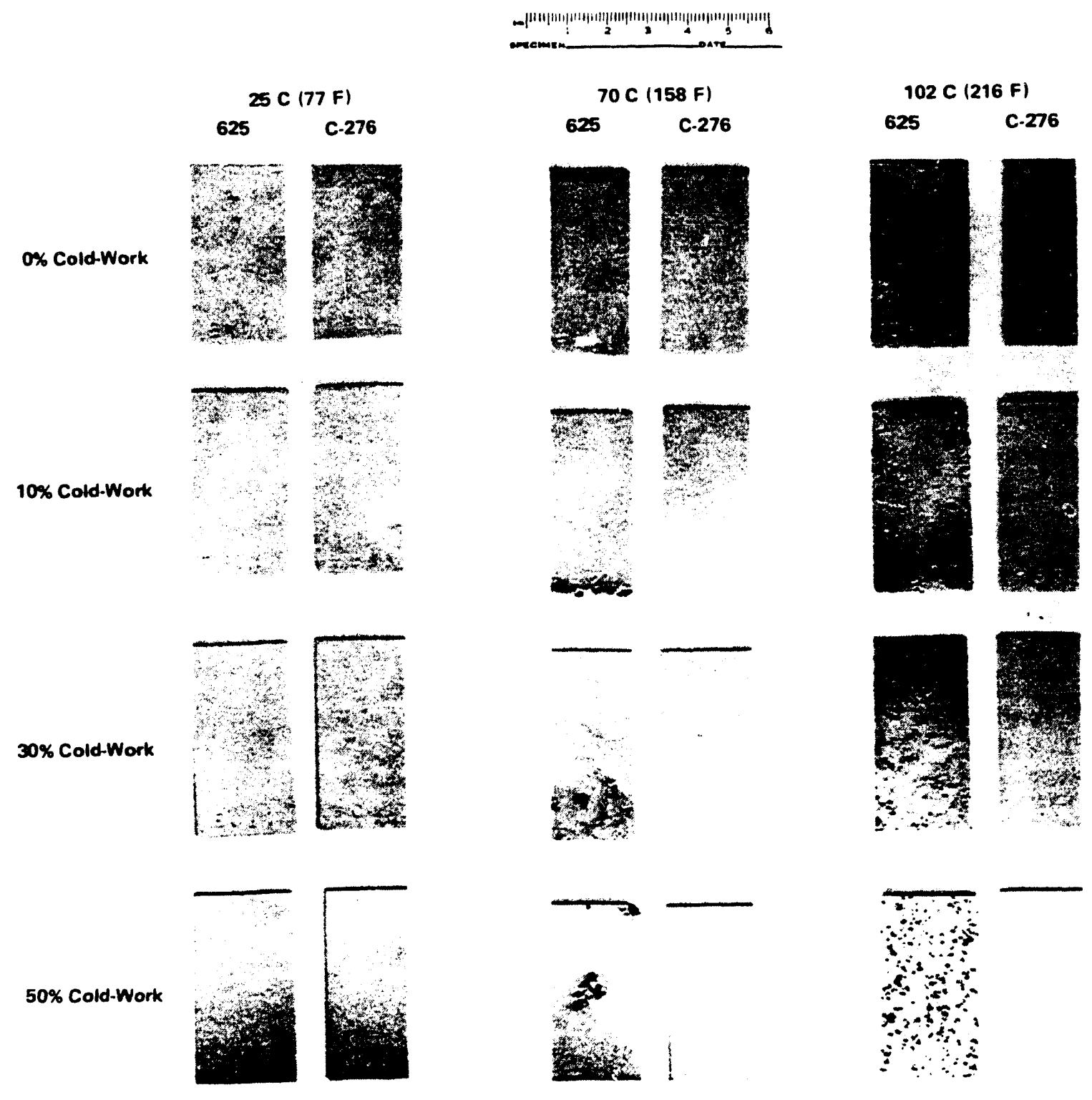

Figure 19. Effect of cold work on the resistance of Alloys 625 and C-276 to localized corrosive attack (Asphahani 1980b). Conditions: 24-h exposure; 7 vol\% $\mathrm{H}_{2} \mathrm{SO}_{4}+3 \mathrm{vol} \% \mathrm{HCl}+1 \mathrm{wt} \% \mathrm{CuCl}_{2}+1 \mathrm{wt} \%$ $\mathrm{FeCl}_{3}$.

pitting temperature $\left(\geq 150^{\circ} \mathrm{C}\right)$ and crevice corrosion temperature $\left(102^{\circ} \mathrm{C}\right)$. Alloy $\mathrm{C}-276$ had the next highest resistance, with critical pitting and crevice corrosion temperatures of 150 and $80^{\circ} \mathrm{C}$, respectively. The least resistant alloys were Alloy 825 and Type 316 stainless steel, which had significantly lower critical pitting $(25$ and $20^{\circ} \mathrm{C}$ ) and critical crevice corrosion (both $\leq-5^{\circ} \mathrm{C}$ ) temperatures. Alloy 625 had intermediate values of critical pitting temperature $\left(90^{\circ} \mathrm{C}\right)$ and critical crevice corrosion temperature $\left(50^{\circ} \mathrm{C}\right)$.

\subsection{Electrochemical Tests}

\subsubsection{Anodic Polarization Curves for the Evaluation of Susceptibility to Crevice Corrosion}

Susceptibility to localized forms of corrosion has been correlated with certain characteristics of anodic polarization curves. Wilde and Williams (1971) performed anodic polarization measurements with several alloys that had been previously evaluated in 
Table 24. Critical pitting temperatures for nickel alloys evaluated in $6 \% \mathrm{FeCl}_{3}$ for $24-\mathrm{h}$ periods (Hibner 1986).

\begin{tabular}{lc}
\hline Alloy & $\begin{array}{c}\text { Critical pitting } \\
\text { temperature } \\
\left({ }^{\circ} \mathrm{C}\right)\end{array}$ \\
\hline C-22 & $\mathbf{7 0 . 0 , 7 0 . 0}$ \\
C-276 & $60.0,65.0$ \\
Allcorr & $52.5,52.5$ \\
625 & $35.0,40.0$ \\
C-4 & $37.5,37.5$ \\
G-3 & $25.0,25.0$ \\
G & $23.0,25.0$ \\
Type 317LM stainless steel & $2.5,2.5$ \\
904L & $2.5,5.0$ \\
825 & $0.0,0.0$ \\
\hline
\end{tabular}

Table 25. Comparative immersion critical pitting and critical crevice-corrosion temperatures in oxidizing $\mathrm{NaCl}-\mathrm{HCl}$ solution (Haynes 1987b).

\begin{tabular}{lcc}
\hline \multicolumn{1}{c}{ Alloy } & $\begin{array}{c}\text { Critical pitting } \\
\text { temp }\left({ }^{\circ} \mathrm{C}\right)\end{array}$ & $\begin{array}{c}\text { Critical crevice- } \\
\text { corrosion temp }\left({ }^{\circ} \mathrm{C}\right)\end{array}$ \\
\hline $\mathrm{C}-22$ & $>150$ & 102 \\
$\mathrm{C}-276$ & 150 & 80 \\
625 & 90 & 50 \\
825 & 25 & $\leq-5$ \\
Type 316 & 20 & $\leq-5$ \\
stainless steel & & \\
\hline
\end{tabular}

Solution: $4 \% \mathrm{NaCl}+0.1 \% \mathrm{Fe}_{2}\left(\mathrm{SO}_{4}\right)_{3}+0.01 \mathrm{M} \mathrm{HCl} ; 24,300 \mathrm{ppm}$ chlorides; $\mathbf{p H}=2$.

seawater for more than two years. They obtained two potentials-the criticai potential for pitting, $E_{\mathrm{c}}$, and the protection or repassivation potential, $E_{\mathrm{p}}$-from cyclic potentiodynamic anodic polarization curves for metals containing synthetic crevices. The critical potential for pitting was defined as the potential at which the current density begins to increase in the transpassive region, and the protection potential was defined as the potential at which the downward scan intercepted the upward scan. Figure 20 illustrates polarization curves from which these potentials were obtained for Alloys $C, 825$, and
$20 \mathrm{Cb}-3$ (Wilde and Williams :971). The smaller the difference between the two potentials (or equivalently, the less hysterisis), the greater the resistance to LC.

Figure 20 shows that there is no potential difference
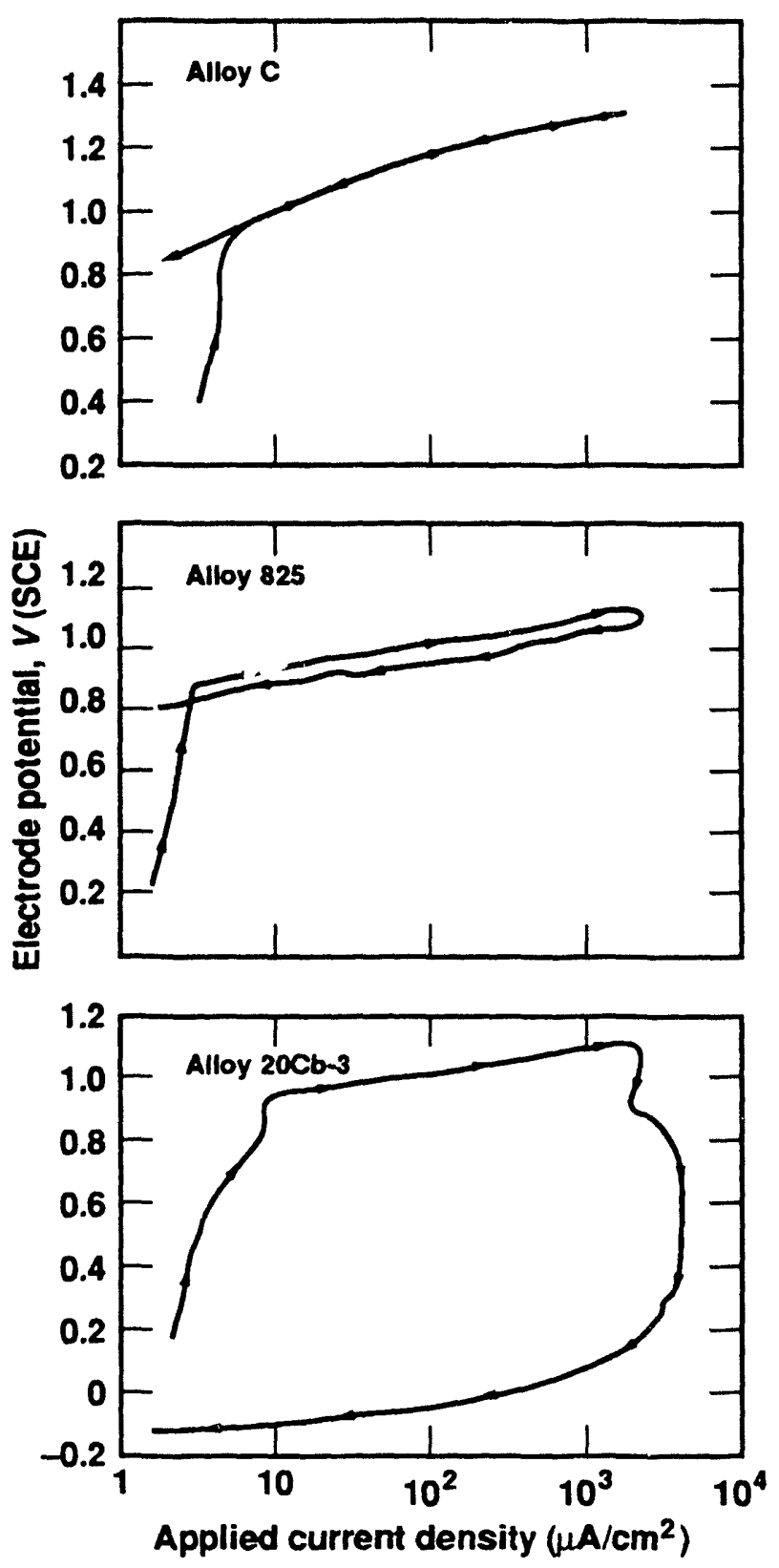

Figure 20. "Cyclic" potentiodynamic anodic polarization curve for Alloys $\mathrm{C}, 825$, and $20 \mathrm{Cb}-3$ in an aerated solution of $3.5 \mathrm{wt} \% \mathrm{NaCl}$ at $25^{\circ} \mathrm{C}$ (Wilde and Williams 1971). Each contained a synthetic crevice. Note the difference in the potential where the reverse sweep intercepts the forward sweep portion of the curves. (Some extrapolation is required for Alloy $20 \mathrm{Cb}-3$.) 
Table 26. Crevice-corrosion weight-loss data for several alloys exposed to seawater for two years (Wilde and Williams 1971).

\begin{tabular}{lcc}
\hline Alloy & $\begin{array}{c}\text { Crevice-corrosion } \\
\text { weight loss } \\
\left(\mathbf{m g} / \mathrm{cm}^{2}\right)\end{array}$ & $\begin{array}{c}\text { Difference between } \\
\text { pitting and } \\
\text { protection potentials }\end{array}$ \\
\hline $\mathrm{C}$ & 0.16 & 0 \\
825 & 4.1 & 0.06 \\
$20 \mathrm{Cb}-3$ & 26.1 & 1.1 \\
\hline
\end{tabular}

- Difference was estimated from Fig. 20.

for Alloy C that is not susceptible to crevice corrosion, but there are small and large potential differences for Alloys 825 and $20 \mathrm{Cb}-3$ that exhibit crevice corrosion. The authors suggested that the difference between the pitting and protection potentials of several alloys (difference potential) correlates with the extent of crevice corrosion after more than two years in seawater (Table 26).

\subsubsection{Potentiostatic Tests}

Asphahani (1980c) has conducted an extensive study on the LC of Ni-Cr-Mo alloys. The potentiostatic polarization method of testing defines the damaging potential range in which localized corrosive attack occurs. Asphahani examined the dependence of this potential range on temperature, $\mathrm{pH}$, chloride ion concentration, and molybdenum content. The alloys studied included Type 316 stainless steel and Alloys $825,625, \mathrm{G}$, and C-276.

These constant-potential tests indicated the superior LC resistance of alloys with a high molybdenum content (Asphahani 1980c). The tests were conducted in $3.8 \mathrm{wt} \% \mathrm{FeCl}_{3}$ solutions at $70^{\circ} \mathrm{C}$, with specimens held at the constant applied potential for $24 \mathrm{~h}$.

Figure 21 summarizes the results. The ranking for LC resistance of these alloys under the conditions described is as follows: Type 316 stainless steel < Alloy $825<$ Alloy $\mathrm{G}<$ Alloy $625<$ Alloy C-276. A comparison of the molybdenum content of the alloys indicates that the potential required for localized attack becomes more positive with increasing molybdenum content. It is obvious from these experiments that there is a direct correlation between the molybdenum content of an alloy and its resistance to localized attack.

The results obtained by the static potential tests correlate very well with the results presented in the sections above. The alloys with a high molybdenum content (Alloys C-276 and 625) have superior LC resistance compared with those alloys having less molybdenum (Alloy 825 and Type 316 stainless steel).

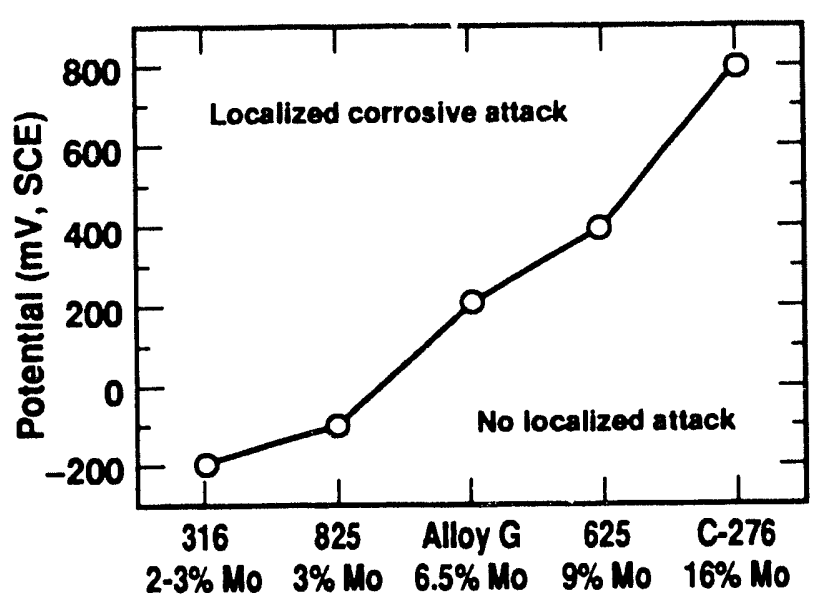

Figure 21. Effect of molybdenum-alloy additions on the LC potential for a constant-applied-potential, 24-h exposure in $3.8 \% \mathrm{FeCl}$ at $70^{\circ} \mathrm{C}$ (Asphahani 1980c).

\subsection{Effects of Gamma Radiation on SCC}

Furuya et al. (1983) reported experiments on the effects of gamma irradiation on SCC in boiling deionized water. The alloys studied were Types 304, 304L, 304EL, and 309S stainless steels, Alloys 825, 600, and 625 , and SMA 50 (a low-alloy steel containing small amounts of manganese and copper). The materials were sensitized by heat treatments at $700^{\circ} \mathrm{C}$ for $100 \mathrm{~min}$ and then at $500^{\circ} \mathrm{C}$ for $24 \mathrm{hr}$. The samples were formed into double U-bends, some with V-notches, and tested for $\mathbf{1 8 0}$ days. Furuya et al. found that the samples made of Types 304, 304L, and 309S stainless steels exhibited SCC, while the others (Type 304EL and Alloys 825, 600,625 , and SMA 50) did not. This result was obtained both with and without gamma irradiation, but the number of failures with Type 304, particularly at V-notches, was much greater for the irradiated samples. The chloride concentrations were between 0.2 and $2.8 \mathrm{ppm}$.

\subsection{Summary}

The exceptional LC resistance of the $\mathrm{Ni}-\mathrm{Cr}-\mathrm{Mo}$ alloys is believed to be due to both their high nickel and high molybdenum contents. For example, Alloys 625 and $\mathrm{C}-276$ are not only immune to $\mathrm{SCC}$ in acidic $\mathrm{NaCl}$ solution but also in boiling $42 \% \mathrm{MgCl}_{2}$ solutions. Increasing the molybdenum content of the highchromium, high-nickel stainiess alloys, such as Alloys $20 \mathrm{Cb}-3,825$, and 20-Mod, plays a definite role in improving their resistance to localized attack and SCC. 


\section{Corrosion in Marine Atmospheres and Brines}

The Ni-Cr-Mo alloys generally have excellent resistance to uniform corrosion, pitting, crevice corrosion, and SCC in marine environments, i.e., aqueous chloride environments. The alloys with 16 to $22 \%$ chromium and 9 to $18 \%$ molybdenum are in general the most resistant of the structural metals to all known marine environments (Fink and Boyd 1970). The titanium-base metals alone have comparable resistance (Fink and Boyd 1970). The resistance of these alloys to uniform corrosion is attributable to the high chromium content ( $\geq 15 \mathrm{wt} \%$ ), the resistance to pitting and crevice corrosion is attributable to the high molybdenum content ( $\geq 9 w t \%$ ), and the resistance to SCC is attributable to the high nickel content ( $\geq 50 \mathrm{wt} \%$ ). The chromium addition reacts with oxygen to form an adherent oxide layer $\left(\mathrm{Cr}_{2} \mathrm{O}_{3}\right)$, which is resistant to further attack. The maintenance of passive surfaces on nickel alloys requires well aerated conditions. This effect is discussed in more detail in a previous report (Farmer et al. 1988) with regard to the austenitic alloys Types 304 and 316 stainless steels and Alloy 825. The effects of the additions of molybdenum and nickel are discussed in Sec. 3 above and in Vol. 3 of Farmer et al. (1988).

This section is a compilation of marineenvironment and brine-corrosion data of the $\mathrm{Ni}-\mathrm{Cr}-\mathrm{Mo}$ alloys. It includes both marine atmospheric and immersion data on general corrosion, SCC, and LC. Where the data exist, comparisons are made between Types 304L and 316L stainless steels, Alloy 82.5, Cu-30Ni, pure copper, $\mathrm{Ni}-\mathrm{Cu}$ (Alloy 400), and titanium alloys.

Table 27 shows a general classification of nickel alloys according to their corrosion resistance in marine environments (Fink and Boyd 1970). In the "most resistant" class are Alloys C, C-276, 625, MP35N, R-41, Chlorimet-3, and Alloy X. Alloys C and C-276 are considered the most resistant. (Alloy C-276 is the

Table 27. Classification of corrosion resistance of nickel alloys in marine environments (Fink and Boyd 1970).

\begin{tabular}{|c|c|c|}
\hline Alloy & Composition (wt \%) & Remarks \\
\hline \multicolumn{3}{|c|}{ Class I. Most Resistant } \\
\hline $\begin{array}{l}\text { C } \\
\text { C-276 } \\
625 \\
\text { MP35N } \\
\text { Chlorimet-3 } \\
\text { R-41 } \\
\text { X }\end{array}$ & $\begin{array}{l}\text { 57Ni-16Cr-17Mo-plus Fe, W, Co } \\
\text { 57Ni-16Cr-17Mo-plus Fe, W, Co } \\
\text { 61Ni-22Cr-9Mo plus Fe, Cb } \\
\text { 35Ni-35Co-20Cr-10Mo } \\
\text { 60Ni-18Cr-18Mo plus Fe, Si } \\
\text { 56Ni-11Co-19Cr-10Mo-3.1Ti } \\
\text { 52Ni-22Cr-9Mo-19Fe plus W, Co }\end{array}$ & $\begin{array}{l}\text { Completely resistant except at welds } \\
\text { Low carbon }(<0.02 \mathrm{C}) \text {; can be welded } \\
\text { Approaches Alloy } \mathrm{C} \text { in total resistance } \\
\text { Excellent, so far, in preliminary experiments } \\
\text { Cast alloy; excellent for pumps etc. } \\
\text { Good-to-excellent resistance to pitting } \\
\text { Good-to-excellent resistance to pi.ting }\end{array}$ \\
\hline \multicolumn{3}{|c|}{ Class II. Very Resistant } \\
\hline $\begin{array}{l}\mathbf{F} \\
\mathbf{G} \\
\text { Illium R } \\
\mathbf{7 0 0} \\
\text { Elgiloy } \\
\mathbf{7 1 8}\end{array}$ & $\begin{array}{l}\text { 46Ni-22Cr-7Mo-21Fe } \\
\text { 45Ni-21Cr-7Mo-20Fe-2Cu-2.5Co } \\
\text { 68Ni-21Cr-5Mo-3Cu } \\
\text { 46Ni-28Co-15Cr-4Mo plus } \mathrm{Ti}, \mathrm{Al} \\
\text { 15Ni-40Co-20Cr-7Mo-15Fe-2Mo } \\
\text { 53Ni-19Cr-3Mo-18Fe plus Co, Ti, Al }\end{array}$ & $\begin{array}{l}\text { Usually satisfactory: molybdenum content } \\
\text { provides resistance to pitting }\end{array}$ \\
\hline \multicolumn{3}{|c|}{ Class III. Resistant, Some Pitting } \\
\hline $\begin{array}{l}600 \\
\times 750 \\
800 \\
825 \\
400 \\
\text { K500 }\end{array}$ & $\begin{array}{l}\text { 76 } \mathrm{Ni}-16 \mathrm{Cr}-7 \mathrm{Fe} \\
\text { 73Ni-15Cr-7Fe plus } \mathrm{Cb}, \mathrm{Ti}, \mathrm{Al} \\
\text { 32Ni-21 } \mathrm{Cr}-46 \mathrm{Fe} \\
\text { 42Ni-22Cr-30Fe-3Mo-2Cu } \\
66 \mathrm{Ni}-32 \mathrm{Cu}-2 \mathrm{Fe} \\
65 \mathrm{Ni}-30 \mathrm{Cu}-1 \mathrm{Fe}-3 \mathrm{Al}\end{array}$ & $\begin{array}{l}\text { May be some pitting at sites where seawater } \\
\text { is stagnant }\end{array}$ \\
\hline
\end{tabular}


Table 28. Represericative solution composition of seawater (major ions) (Braithwaite and Molecke 1980).

\begin{tabular}{|c|c|}
\hline Ion & ppm \\
\hline $\mathrm{Na}^{+}$ & 10,651 \\
\hline $\mathbf{K}^{+}$ & 380 \\
\hline $\mathbf{M g}^{2+}$ & 1,272 \\
\hline $\mathrm{Ca}^{2+}$ & 400 \\
\hline $\mathbf{S r}^{2}$ & 13 \\
\hline $\mathrm{Cr}$ & 18,980 \\
\hline $\mathrm{SO}_{4}{ }^{2-}$ & 884 \\
\hline $\mathbf{I}^{-}$ & 5 \\
\hline $\mathrm{HCO}_{3}^{-}$ & 146 \\
\hline Br & 65 \\
\hline pH & 8.1 \\
\hline Total dissolved solids & $35 \mathrm{~g} / 1$ \\
\hline
\end{tabular}

low-carbon, low-silicon version of Alloy $\mathrm{C}$, and it has better corrosion resistance at welds.) Ailloy 625 is classified as slightly less resistant than Alloy C-276. Alloys MP35N and R-41 both contain substantial amounts of cobalt and are much more expensive than the other alloys. Chlorimet- 3 is a cast alloy. Alloy 825 and Alloy 400 are two classifications lower and are in the category "resistant, some pitting." Materials in this classification may pit in stagnant seawater. [Types 304 and 316 stainiess steels are less corrosion-resistant than Alloy 825 in marine environments (Farmer et a'. 1988).]

It is known that the corrosivity of chloride ion solutions is also dependent on the cation species present (Farmer et al. 1988). A rece 7 t study suggests that magnesium ions are very aggressive species in seawater even though they represent only a fraction of the total dissolved solids (Shoki and Ohriaka 1989). Table 28 gives a composition analysis of seawater.

\subsection{Marine Atmospheric Corrosion}

Long-term atmospheric corrosion and stress corrosion tests of numerous materials have been performed at Kure Beach, N.C. (Baker 1988). The tests were conducted by the LaQue Center for Corrosion Technology of Wrightsville Beach, N.C. In these studies, specimens were exposed in lots located 25 and $250 \mathrm{~m}$ from the Atlantic Octan. The atmospheres at these sites are highly corrosive (25-m lot) and moderately corrosive (250-m lot).

The corrosion tests were set up according to ASTM Recommended Practices. Corrosion test panels were prepared for exposure and then exposed on test racks positioned $30 \mathrm{deg}$ to the horizon and facing south (ASTM Standard G1). The panels were mounted in porcelain insulators that galvanically insulated each panel (ASTM Standard G50).

Two-point loaded bent-beam stress corrosion specirnens were cut to precise dimensions. The length was calculated such that the amount of deflection would stress the specimens to $90 \%$ of the yield stress (ASTM Standard G39). Some specimens were cut from welded stock. The weld ran the width of the specimen and was located in the center at a point that would have the greatest deflection. Specimens were mounted in suress jigs and exposed in the 25-m marine atmospheric test lot.

A group of several alloys was exposed in the $250-\mathrm{m}$ marine . 1ospheric lot beginning on May 14, 1941. The materials included several stainless steels, 70/30 coppernickel, Alloy $\mathrm{C}$, and five other nickel-base alloys. Testing on these specimens is still continuing. The stainless steels displayed varying amounts of rust and rust stain on the panel surface, depending on the alloy type, but the passive film generally provided good corrosion resistance. The copper-based alloys, coppernickel alloys, and nickel-copper alloys generate an adherent oxide film that provides good corrosion resistance. The nickel-base alloys generate an oxide film which is sometimes so thin that it cannot be seen; this film provides excellent resistance to corrosion. Test panels of Alloy C and Stellite (a cobalt-base alloy), prepared to a mirror polish, were exposed in the $250-\mathrm{m}$ lot beginning on May 14, 1942. Both materials are still being exposed and retain a reflective mirror surface.

Table 29 shows a group of nickel-base alloys that exhibit long-term resistance to marine atmospheric corrosion $(\leq 1 \mu \mathrm{m} / \mathrm{yr}$ ) (Baker 1988). Included among these alloys are Alloys $825,600,625,400$, and C. Corrosion characteristics for Alloy 600 and Alloy 400 at 36 yr are also included in the table. Alloy 400 corroded at a rate of $0.3 \mu \mathrm{m} / \mathrm{yr}$ and had a maximum pit depth of $0.1 \mathrm{~mm}$. Alloy 600 corroded at a rate of $0.008 \mu \mathrm{m} / \mathrm{yr}$ and had a maximum pit depth of $0.1 \mathrm{~mm}$. Alloys $C$ and 625 usually have better corrosion resistance than Alloys 600 and 400 in seawater (see Table 27).

Stress corrosion testing of various materials was initiated in 1961. Test specimens were in the form of two-point-loaded bent beams. The specimens were first exposed for six months in seawater and then re-exposed in the marine atmosphere $25 \mathrm{~m}$ from the ocean. Welded and nonwelded Alloy $C$ specimens stressed at 59 and 
Table 29. Some nickel-base alloys exhibiting longterm marine atmospheric corrosion resistance $(1 \mu \mathrm{m} / \mathrm{yr})$. Results were reported by Baker in 1988.

\begin{tabular}{lll}
\hline \multicolumn{1}{c}{ Material } & $\begin{array}{c}\text { Exposure } \\
\text { duration } \\
(\mathbf{y r})\end{array}$ & $\begin{array}{c}\text { Exposure } \\
\text { location' } \\
\text { from ocean) }\end{array}$ \\
\hline Alloy 400 & 45 & 250 \\
Alloy K-500 & 45 & 250 \\
Alloy 200 & 45 & 250 \\
Permanickel & 45 & 250 \\
Alloy 600 & 44 & 250 \\
Electrolytic nickel & 44 & 250 \\
Alloy C & 44 & 250 \\
Stellite & 44 & 250 \\
Alloy 800 & 28 & 25 and 250 \\
Alloy 825 & 28 & 25 and 250 \\
Alloy X-750 & 26 & 25 \\
Alloy 718 & 26 & 25 \\
Alloy 625 & 21 & 25 and 250 \\
\hline
\end{tabular}

a 250-m lot. The exposure area is $250 \mathrm{~m}$ from the ocean (mean tide). The test panels are positioned $30 \mathrm{deg}$ to the horizontal, facing southward for maximum solar exposure. Airborne salt particles (chloride lons) carried by easterly winds generated a moderately corrosive environment. Annual chloride ion concentration varies from 70 to $20 \mathrm{~g} / \mathrm{m}^{2} / \mathrm{gr}$ [see Fig. 3 in Baker (1988)].

25-m lot. The exposure area is $25 \mathrm{~m}$ from the ocean (mean tide). The test panels are positioned $30 \mathrm{deg}$ to the horizontal, facing the surf in an eastern direction. The ocean waves and surf provide a continuous source of airborne salt particles (chloride ions), generating a severely corrosive environment. Annual chloride ion concentration varies from 250 to $60 \mathrm{~g} / \mathrm{m}^{2} / \mathrm{yr}$ [see Fig. 2 in Baker (1988)].

b Evaluations of test panets of Alloys 400 and 600 at $36 \mathrm{yr}$ were as follows: (1) Alloy 400: corrosion rate was $0.3 \mu \mathrm{m} / \mathrm{gr}$, and pit depth was $100 \mu \mathrm{m}$ maximum. (2) Alloy 600: corrosion rate was $0.008 \mu \mathrm{m} / \mathrm{yr}$, and pit depth was $100 \mu \mathrm{m}$ maximum.

$57 \mathrm{ksi}$ showed no signs of cracking after $25 \mathrm{yr}$ of testing. Also, a welded specimen of Alloy C clad over HR 4330 did not show signs of cracking. The stress was not recorded for this specimen.

Intermediate results have been reported on this continuing study. Weisert reported in 1957 that Alloy C specimens exposed to salt water air at Kure Beach, N.C., since May 1942 had retained their original mirrorpolish finish. Also, Asphahani reported in 1980 that Ailoy $C$ test specimens were uncorroded after more than 30 yr of exposure.
The good atmospheric corrosion resistance of Alloy 400 has also been reported in the results of a 16-yr study in the Panama Canal Zone (Table 30) (South:vell et al. 1976). Corrosion rates were low in both coastal $(0.25 \mu \mathrm{m} / \mathrm{yr})$ and inland $(<0.25 \mu \mathrm{m} / \mathrm{yr})$ environments. There was no evidence of pitting within the detection limit. In this study, the atmospheric corrosion resistance of Alloy 400 was better than that of either pure copper or $\mathrm{Cu}-30 \mathrm{Ni}$.

\subsection{Marine Immersion Corrosion}

\subsubsection{General Performance}

The Ni-Cr-Mo alloys generally have excellent corrosion resistance in both high- and low-velocity seawater (Table 27). Alloys C-276 and 625 show exceptional resistance, with general corrosion rates of less than $1.27 \mu \mathrm{m} / \mathrm{yr}$ (detection limit). In addition, these alloys are usually free of pitting and crevice attack under fouling in quiet (stagnant) or low-velocity exposure, a condition that may cause failure of many other metallic materials, such as Types 304 and 316 stainless steels.

Nickel-copper alloys (e.g., Alloy 400) have good corrosion resistance in seawater except for slowly moving or stagnant seawater, in which they are subject to pitting, particularly if fouling organisms are present and attach themselves to the metal. The resistance to corrosion results from the formation of a passive layer, hence, when oxygen is deficient the passive layer can be destroyed, and pitting and crevice corrosion can result.

The corrosion resistances of several high-nickel alloys have been reported for two-year tests in quiet (stagnant) and flowing ( $2 \mathrm{fps}$ ) seawater at Wrightsville Beach, N.C. Tables 31 and 32 show the results of these tests (Niederberger et al. 1970). The materials with the best corrosion resistance were Alloy C-276 and Alloy 625 (Table 33). These alloys suffered insignificant weight loss and no pitting or crevice corrosion. In comparison, the weight loss observed in Alloy 825 was insignificant in quiet seawater but measurable in flowing seawater. More significantly, however, Alloy 825 suffered considerable amounts of pitting and crevice corrosion. Maximum pit depths of 740 and $1300 \mu \mathrm{m}$ were measured in quiet and flowing seawater, respectively. Alloy 400 suffered significant weight loss and pitting in both quict and flowing seawater. None of the alloys suffered SCC in U-bend tests in the flowing seawater.

In a comparable test ( $1.06 \mathrm{yr}$ in duration) in nearsurface seawater, Type 304 stainless steel and Alloy 825 suffered severe pitting and crevice corrosion 
Table 30. Corrosion of nickel-copper Alloy 400 (70 Ni-30Cu) in aqueous environments (Southwell et al. 1976). Results are for 16-year tests that were performed in the Panama Canal Zone.

\begin{tabular}{llcc}
\hline $\begin{array}{c}\text { Alloy } \\
\text { condition }\end{array}$ & \multicolumn{1}{c}{$\begin{array}{c}\text { Final steady-state } \\
\text { corrosion rate } \\
(\mu \mathrm{m} / \mathrm{yr})\end{array}$} & $\begin{array}{c}\text { Deepest pit } \\
(\mu \mathrm{m})\end{array}$ \\
\hline Cold-rolled & \multicolumn{1}{c}{ Seawater immersion (depth 1 to $5 \mathrm{~m})$} & 7.6 & 1400 \\
Cold-rolled & Seawater mean tide & 5.1 & 610 \\
Cold-rolled & Lake (fresh) water immersion (depth 2 m) & 1.0 & 1350 \\
Cold-rolled & Atmospheric coastal & 0.25 & $<127^{b}$ \\
Cold-rolled & Atmospheric inland & $<0.25^{\mathrm{b}}$ & $<127^{\mathrm{b}}$ \\
Hot-rolled & Seawater immersion (depth 1 to 5 m) & 7.6 & 2100 \\
Hot-rolled & Seawater mean tide & 5.1 & 900 \\
\hline
\end{tabular}

- Mean-tide immersion means that specimens were placed such that they were immersed in seawater half of the exposure time on a daily basis. This pattern occurred because of water level changes due to tidal forces.

b Detection limit.

Table 31. Corrosion of Ni-Cr-Mo alloys by quiet seawater at Wrightsville Beach, N.C. (Niederberger et al. 1970). The duration of the test was two years.

\begin{tabular}{|c|c|c|c|c|c|c|}
\hline \multirow[b]{2}{*}{ Alloy } & \multirow[b]{2}{*}{$\begin{array}{l}\text { Major alloy content } \\
(\text { (wt \%) }\end{array}$} & \multirow[b]{2}{*}{$\begin{array}{l}\text { Weight loss } \\
\text { (g) }\end{array}$} & \multicolumn{3}{|c|}{ Range of pit depth ( $\mu \mathrm{m})$} & \multirow[b]{2}{*}{$\mathrm{SCC}$} \\
\hline & & & Panel & $\begin{array}{c}\text { Crevice } \\
\text { area }\end{array}$ & Coupon & \\
\hline $\mathbf{R}-41$ & $54 \mathrm{Ni}-19 \mathrm{Cr}-10 \mathrm{Mo}-11 \mathrm{Co}$ & 0.80 & NiI & Nil & Nil & No \\
\hline $\mathbf{X}$ & $47 \mathrm{Ni}-22 \mathrm{Cr}-9 \mathrm{Mo}-18 \mathrm{Fe}$ & 0.10 & Nil & Nil & $127-660$ & No \\
\hline $\mathbf{N}$ & $69 \mathrm{Ni}-7 \mathrm{Cr}-16 \mathrm{Mo}-4 \mathrm{Fe}$ & 0.50 & Nil & $0-51$ & $127-381$ & No \\
\hline 825 & $42 \mathrm{Ni}-21 \mathrm{Cr}-3 \mathrm{Mo}-30 \mathrm{Fe}-2 \mathrm{Cu}$ & 0.25 & $0-25$ & $0-229$ & $737-1295$ & No \\
\hline 625 & $62 \mathrm{Ni}-22 \mathrm{Cr}-9 \mathrm{Mo}-2 \mathrm{Fe}$ & Nil & Nil & Nil & Nil & No \\
\hline Illium R & $66 \mathrm{Ni}-20 \mathrm{Cr}-5 \mathrm{Mo}-6 \mathrm{Fe}-3 \mathrm{Cu}$ & 0.20 & Nil & $356-635$ & $330-838$ & No \\
\hline C & $56 \mathrm{Ni}-16 \mathrm{Cr}-16 \mathrm{Mo}-4 \mathrm{~W}$ & Nil & Nil & Nil & Nil & No \\
\hline 718 & $53 \mathrm{Ni}-18 \mathrm{Cr}-3 \mathrm{Mo}-18 \mathrm{Fe}-5 \mathrm{Ch}$ & 2.70 & Nil & $940-4191 P^{a}$ & $1168-4191 \mathrm{~Pa}^{\mathrm{a}}$ & No \\
\hline 901 & $42 \mathrm{Ni}-12 \mathrm{Cr}-6 \mathrm{Mo}-35 \mathrm{Fe}$ & 1.48 & $0-279$ & $762-3454$ & $432-1930$ & No \\
\hline $400^{b}$ & $65 \mathrm{Ni}-35 \mathrm{Cu}$ & 20.40 & $0-508$ & $762-813$ & $432-737$ & No \\
\hline $\mathrm{K} 500^{\mathrm{b}}$ & $60 \mathrm{Ni}-40 \mathrm{Cu}$ & 23.80 & $457-483$ & $254-330$ & $381-457$ & No \\
\hline
\end{tabular}

P, perforated by local attack.

b Approximately, I.e, specimens had approximate compositions of Alloys 400 and K500.

Panel specimens $(30.5 \mathrm{~cm} \times 7.6 \mathrm{~cm} \times 0.318 \mathrm{~cm})$ were attached with ceramic insulators to supporting panels. Two specimens of each alloy were suspended from rafts in the seawater. Crevices were made by bolting $2.54 \times 2.54 \mathrm{~cm}$ counons of the same alloy as the panel at the center and on each side of the test panel. Nuts and bolts were made of nylon material. The SCC test ccnsisted of four U-bend-stressed specimens of each alloy. The stressed regions were immersed in nowing seawater for two years. Specimens were $40.64 \mathrm{~cm}$ lung, $2.54 \mathrm{~cm}$ wide, and 0.318 to $0.475 \mathrm{~cm}$ thick. Stress levels were not given. 
Table 32. Corrosion of Ni-Cr-Mo and $\mathrm{Ni}-\mathrm{Cu}$ alloys by slowly moving seawater $(0.3$ to $0.6 \mathrm{~m} / \mathrm{s})$ at Wrightsville Beach, N.C. (Niederberger et al. 1970). Test conditions are identical to those given in Table 31 .

\begin{tabular}{|c|c|c|c|c|c|c|}
\hline \multirow[b]{2}{*}{ Alloy } & \multirow[b]{2}{*}{$\begin{array}{l}\text { Major alloy content } \\
(w t \%)\end{array}$} & \multirow[b]{2}{*}{$\begin{array}{l}\text { Weight loss } \\
\text { (g) }\end{array}$} & \multicolumn{3}{|c|}{ Range of pit depth $(\mu \mathrm{m})$} & \multirow[b]{2}{*}{ SCC } \\
\hline & & & Panel & $\begin{array}{c}\text { Crevice } \\
\text { area }\end{array}$ & Coupon & \\
\hline R-41 & $54 \mathrm{Ni}-19 \mathrm{Cr}-10 \mathrm{Mo}-11 \mathrm{Co}$ & 0.30 & Nil & Nil & Nil & No \\
\hline $\mathbf{x}$ & $47 \mathrm{Ni}-22 \mathrm{Cr}-9 \mathrm{Mo}-18 \mathrm{Fe}$ & 0.60 & Nil & Nil & $0-102$ & No \\
\hline $\mathbf{N}$ & $69 \mathrm{Ni}-7 \mathrm{Cr}-16 \mathrm{Mo}-4 \mathrm{Fe}$ & 1.45 & Nil & $76-102$ & $24-40$ & No \\
\hline 825 & $42 \mathrm{Ni}-21 \mathrm{Cr}-3 \mathrm{Mo}-30 \mathrm{Fe}-2 \mathrm{Cu}$ & 0.20 & $76-152$ & $25-660$ & $102-737$ & No \\
\hline 625 & $62 \mathrm{Ni}-22 \mathrm{Cr}-9 \mathrm{Mo}-2 \mathrm{Fe}$ & 0.25 & Nil & Nil & Nil & No \\
\hline Illium $\mathbf{R}$ & $66 \mathrm{Ni}-20 \mathrm{Cr}-5 \mathrm{Mo}-6 \mathrm{Fe}-3 \mathrm{Cu}$ & 0.15 & $0-51$ & Nil & $584-610$ & No \\
\hline $\mathrm{C}$ & $56 \mathrm{Ni}-16 \mathrm{Cr}-16 \mathrm{Mo}-4 \mathrm{~W}$ & 0.10 & Nil & Nil & Nil & No \\
\hline 718 & $53 \mathrm{Ni}-18 \mathrm{Cr}-3 \mathrm{Mo}-18 \mathrm{Fe}-5 \mathrm{Cb}$ & 5.15 & Nil & $1016-4191 P^{2}$ & $1295-4191 P^{2}$ & No \\
\hline 901 & $42 \mathrm{Ni}-12 \mathrm{Cr}-6 \mathrm{Mo}-35 \mathrm{Fe}$ & 1.00 & Nil & $711-2464$ & $508-2794$ & No \\
\hline $400^{b}$ & $65 \mathrm{Ni}-35 \mathrm{Cu}$ & 21.10 & 254-381 & $610-686$ & $686-787$ & No \\
\hline $\mathbf{K 5 0 0 ^ { \mathrm { b } }}$ & $60 \mathrm{Ni}-40 \mathrm{Cu}$ & 30.10 & $356-508$ & $381-762$ & $533-711$ & No \\
\hline
\end{tabular}

2 P, perforated by local attack.

b Approximately.

Table 33. Corrosion rating of nickel alloys based on the infurmation in Tables 31 and 32 (Niederberger et al. 1970).

\begin{tabular}{ll}
\hline \multicolumn{1}{c}{ Classification } & Alloy \\
\hline No attack & C \\
& $\mathbf{6 2 5}$ \\
& R-41 \\
Little or no pitting on boldly & X \\
exposed areas, minor attack & N \\
in crevices & 825 \\
& Illium R \\
Little or no pitting on boldly & 718 \\
exposed surfaces, moderate & 901 \\
to severe attack in crevices & \\
General corrosion and & 400 \\
moderate localized attack & K500 \\
\hline
\end{tabular}

(Wheatfall 1967). Table 34 shows the results of this test, and Table 35 gives the experimental conditions. In the crevice region, Type 304 stainless steel had pits that perforated the specimen $(1600 \mu \mathrm{m})$, and Alloy 825 had a maximum pit depth of $1450 \mu \mathrm{m}$. A Cu-Ni(30) specimen was also tested; it suffered only slight crevice corrosion and had a uniform corrosion rate of $5.5 \mu \mathrm{m} / \mathrm{yr}$.

Other studies have also shown that Alloy 400 is susceptible to both corrosion and pitting in seawater (Table 30). In a 16-yr test in the Panama Canal Zone, corrosion rates at $16 \mathrm{yr}$ were on the order of $5 \mu \mathrm{m} / \mathrm{yr}$, and there was significant pitting of the specimens. Pure copper and $70 \mathrm{Cu}-30 \mathrm{Ni}$ were also tested, and both had better corrosion and pitting resistance than Alloy 400 . A 2-yr test in the Pacific Ocean also showed that Alloy 400 was susceptible to significant pitting and corrosion (12 $\mu \mathrm{m} / \mathrm{yr})$; in comparison, aluminum bronze (Al 5.5\%) was not susceptible to pitting (Brouillette 1958).

Other studies have shown the excellent corrosion resistance of some $\mathrm{Ni}-\mathrm{Cr}-\mathrm{Mo}$ alloys in seawater under various conditions. Weisert (1957) found that Alloy C immersed in seawater for $10 \mathrm{yr}$ suffered no detectable weight loss ( $<2.54 \mu \mathrm{m} / \mathrm{yr}$; detection limit) and no pitting. Long-term corrosion tests ( $7 \mathrm{yr}$ ) of Alloy 625 have been performed in quiet seawater flowing at a rate of $2 \mathrm{fps}$ (Table 36) (Friend 1980). The specimens were plain, crevice, and welded. Corrosion rates were small $(<2.5 \mu \mathrm{m} / \mathrm{yr})$, and LC was detected only at $7 \mathrm{yr}$ on two plain specimens. In quiet seawater, incipient corrosion was found below attached fouling. In flowing seawater, crevice corrosion was found beneath a Teflon washer (pit depth was $280 \mu \mathrm{m}$ ). Alloy MP35N showed no 
Table 34. General corrosion experiments in seawater (Wheatfall 1967). Exposure conditions are shown in Table 35.

\begin{tabular}{|c|c|c|c|c|c|c|}
\hline \multirow[b]{3}{*}{ Alloy } & \multicolumn{4}{|c|}{ Corrosion rate (mdd $\left.{ }^{\mathbf{a}}\right)$} & \multirow{3}{*}{$\begin{array}{c}\text { Surface attack } \\
\text { (outside crevice area) }\end{array}$} & \multirow{3}{*}{$\begin{array}{c}\text { Crevice attack } \\
\text { (maximum pit depth) }\end{array}$} \\
\hline & \multicolumn{4}{|c|}{ Exposure No. } & & \\
\hline & 1 & 2 & 3 & 4 & & \\
\hline Type 304 & $5.91^{b}$ & $8.51^{b}$ & $5.31^{b}$ & $3.15^{b}$ & $\begin{array}{l}\text { No visible pits in No. } 1 . \\
\text { Severe pitting and edge } \\
\text { attack at scattered areas } \\
\text { in Nos. } 2 \text { and } 3 \text {. Attack } \\
\text { along all edges and } \\
\text { perforations }(1600 \mu \mathrm{m}) \text { at } \\
\text { scattered pits in No. } 4 \text {. }\end{array}$ & $\begin{array}{l}\text { Inside crevice: } \\
\text { No. } 1=790 \mu \mathrm{m} \text {, } \\
\text { Nos. } 2,3=3200 \mu \mathrm{m} \\
\text { (perforated), } \\
\text { No. } 4=1600 \mu \mathrm{m} \\
\text { (perforated). }\end{array}$ \\
\hline $\mathrm{Cu}-\mathrm{Ni}(30)$ & $\begin{array}{c}6.27 \\
\left(25.6^{c}\right)\end{array}$ & $\begin{array}{c}2.75 \\
\left(11.24^{c}\right)\end{array}$ & $\begin{array}{c}3.08 \\
\left(12.6^{c}\right)\end{array}$ & $\begin{array}{c}1.42 \\
(5.8 \mathrm{c})\end{array}$ & $\begin{array}{l}\text { Etched in Nos. } 1 \text { and } 4 . \\
\text { Etched and streaked in } \\
\text { Nos. } 2 \text { and } 3 .\end{array}$ & $\begin{array}{l}\text { No attack in No. } 1 . \\
\text { Slight attack at crevice } \\
\text { entrance in Nos. } 2,3 \text {, } \\
\text { and } 4 .\end{array}$ \\
\hline $\begin{array}{l}\text { Copper } \\
\text { (unalloyed) }\end{array}$ & $\begin{array}{c}12.1 \\
\left(49.6^{c}\right)\end{array}$ & $\begin{array}{c}3.78 \\
\left(15.5^{c}\right)\end{array}$ & $\begin{array}{c}2.65 \\
\left(10.87^{c}\right)\end{array}$ & $4.50^{b}$ & $\begin{array}{l}\text { Slight surface etching in } \\
\text { Nos. } 1,2 \text {, and } 3 \text {. Etching } \\
\text { and moderate edge attack } \\
\text { in No. } 4 .\end{array}$ & $\begin{array}{l}\text { No attack in Nos. } 1 \\
\text { and } 2 . \text { At crevice } \\
\text { entrance: No. } 3= \\
25.4 \mu \mathrm{m}, \text { No. } 4= \\
127 \mu \mathrm{m} \text {. }\end{array}$ \\
\hline 825 & $\begin{array}{c}0.634 \\
\left(2.85^{c}\right)\end{array}$ & $2.31^{b}$ & - & $0.218^{b}$ & $\begin{array}{l}\text { No visible attack in No. } 1 \text {. } \\
\text { Scattered pitting to } 25.4 \mu \mathrm{m} \\
\text { (No. 2) and } 50.8 \mu \mathrm{m} \text { (No. } 4 \text { ) }\end{array}$ & $\begin{array}{l}\text { Inside crevice: } \\
\text { No. } 1=\text { incipient, } \\
\text { No. } 2=1600 \mu \mathrm{m} \\
\text { (perforated), } \\
\text { No. } 4=1450 \mu \mathrm{m} .\end{array}$ \\
\hline $\mathrm{C}$ & $\begin{array}{l}0.560 \\
\left(2.30^{c}\right)\end{array}$ & $\begin{array}{c}0.022 \\
\left(0.09^{c}\right)\end{array}$ & - & - & $\begin{array}{l}\text { No visible attack in any } \\
\text { exposure. }\end{array}$ & None \\
\hline $\begin{array}{l}\text { Titanium } \\
\text { (unalloyed) }\end{array}$ & $\begin{array}{l}0.601 \\
\left(4.88^{c}\right)\end{array}$ & $\begin{array}{l}0.005 \\
\left(0.04^{c}\right)\end{array}$ & - & - & $\begin{array}{l}\text { No visible attack in any } \\
\text { exposure. }\end{array}$ & None \\
\hline
\end{tabular}

add, milligrams per square decimeter per day.

b Weight loss is attributed largely to localized corrosion.

c Corrosion rate in $\mu \mathrm{m} / \mathrm{yr}$ assuming uniform corrosion.

Table 35. Experimental conditions under which the tests described in Table 34 were conducted.

\begin{tabular}{|c|c|c|c|c|c|c|c|}
\hline $\begin{array}{l}\text { Exposure } \\
\text { No. }\end{array}$ & $\begin{array}{l}\text { Depth and length } \\
\text { of exposure }\end{array}$ & $\begin{array}{l}\text { Salinity } \\
\left(p_{\left.p t^{2}\right)}\right.\end{array}$ & $\begin{array}{c}\text { Oxygen } \\
\text { (ppm) }\end{array}$ & pH & $\begin{array}{c}\text { Temp } \\
\left({ }^{\circ} \mathrm{C}\right)\end{array}$ & $\begin{array}{l}\text { Pressure } \\
\quad \text { (psi) }\end{array}$ & $\begin{array}{r}\text { Current } \\
\text { (knots) }\end{array}$ \\
\hline 1 & $5640 \mathrm{ft}, 123$ days & 34.60 & 1.19 & 7.25 & 2.78 & 2500 & $<0.5$ \\
\hline 2 & 5640 ft, 751 days & 34.59 & 2.14 & 7.48 & 2.39 & 2482 & $<0.5$ \\
\hline 3 & 5300 ft, 1064 days & 34.56 & 1.80 & 7.40 & 2.50 & 2350 & $<0.5$ \\
\hline 4 & Surface, 386 days & 35.05 & 7.38 & 8.01 & 17.61 & Ambient & $1-2$ \\
\hline
\end{tabular}

\footnotetext{
- ppt, parts per thousand.
} 
Table 36. Exposure of Alloy 625 in quiet and flowing seawater (Friend 1980).

\begin{tabular}{|c|c|c|c|c|}
\hline $\begin{array}{c}\text { Specimen } \\
\text { type }\end{array}$ & $\begin{array}{c}\text { Exposure } \\
\text { period } \\
\text { (yr) }\end{array}$ & $\begin{array}{c}\text { Corrosion } \\
\text { rate } \\
(\mu \mathrm{m} / \mathbf{y r})\end{array}$ & Crevice & Pitting \\
\hline \multicolumn{5}{|c|}{ Quiet seawater } \\
\hline Plain & 0.5 & $<2.5$ & Nil & Nil \\
\hline Crevice & 0.5 & $<2.5$ & Nil & Nil \\
\hline Welded & 0.5 & $<2.5$ & Nil & Nil \\
\hline Plain & 1.0 & $<2.5$ & Nil & Nil \\
\hline Crevice & 1.0 & $<2.5$ & Nil & Nil \\
\hline Welded & 1.0 & $<2.5$ & Nil & Nil \\
\hline Plain & 7.0 & $<2.5$ & b & Nil \\
\hline Crevice & 7.0 & $<2.5$ & Nil & Nil \\
\hline Welded & 7.0 & $<2.5$ & Nil & Nil \\
\hline \multicolumn{5}{|c|}{ Flowing seawater $(0.61 \mathrm{~m} / \mathrm{s})$} \\
\hline Plain & 0.5 & $<2.5$ & Nil & Nil \\
\hline Crevice & 0.5 & $<2.5$ & Nil & Nil \\
\hline Plain & 1.0 & $<2.5$ & Nil & Nil \\
\hline Crevice & 1.0 & $<2.5$ & Nil & Nil \\
\hline Welded & 1.0 & $<2.5$ & Nil & Nil \\
\hline Plain & 5.9 & $<2.5$ & $279 \mu \mathrm{m}^{\mathrm{c}}$ & Nil \\
\hline Crevice & 7.0 & $<2.5$ & Nil & Nil \\
\hline Welded & 7.0 & $<2.5$ & Nil & Nil \\
\hline
\end{tabular}

2 Crevice specimens had a 0.49-cm-diam Bakelite washer bolted against their face Welded specimens, intended to simulate conditions of severe stress, were prepared by cutting $0.79-\mathrm{cm}$ circles from the centers of the specimen faces and then welding cut pieces in original positions.

b Incipient crevice attack beneath attached fouling.

c Beneath a Teflon washer.

corrosive attack after 4 yr of immersion in seawater (Fink and Boyd 1970), and no SCC of bolts or U-bend specimens after 2 yr of immersion (Taylor 1970).

\subsubsection{Crevice Corrosion}

Table 37 gives a qualitative ranking of metals and alloys for resistance to crevice corrosion in quiet seawater. Alloy $\mathrm{C}$ and unalloyed titanium are ranked as inert to crevice corrosion. The $70 \mathrm{Cu}-30 \mathrm{Ni}$ alloy is ranked as better than most materials. Unalloyed copper and the austenitic materials Alloy 825 and Types 316 and 304 stainless steels are ranked as below average in their resistance to crevice corrosion. The stainless steels have the least resistance to crevice corrosion.
Table 37. Relative crevice corrosion resistance of metals and alloys in quiet seawater (France 1972).

\begin{tabular}{ll}
\hline \multicolumn{1}{c}{ Metal or alloy } & Resistance \\
\hline Alloy C & Inert \\
Titanium & \\
$90 \mathrm{Cu}-10 \mathrm{Ni}-1.5 \mathrm{Fe}$ & \\
70Cu-30Ni-0.5Fe & Best \\
Bronze & \\
Brass & \\
Austenitic nickel cast iron & \\
Cast iron & Neutral \\
Carbon steel & \\
Alloy 825 & \\
Alloy 20 & Less \\
Ni-Cu alloy & \\
Copper & \\
Type 316 stainless steel & \\
Ni-Cr alloys & \\
Type 304 stainless steel & Pit initiation \\
Series 400 stainless steels & at crevices \\
\hline
\end{tabular}

Alloy $\mathrm{C}$, titaniul ., and $70 \mathrm{Cu}-30 \mathrm{Ni}$ have the same resistance to crevice corrosion in flowing seawater as in quiet (stagnant) seawater. The resistance of the stainless steels is dependent on the flow rate of the seawater.

Table 38 shows quantitative results indicating the superior crevice-corrosion resistance of the $\mathrm{Ni}-\mathrm{Cr}$-Mo alloys in comparison with other austenitic alloys in slow-flowing filtered seawater (Hack 1983). Crevice formers consisted of radially grooved plastic washers that were secured to both sides of each test panel with an insulated titanium fastener. Specimens were in the form of $100 \times 150 \mathrm{~mm}$ panels with thicknesses of about 0.5 to $5 \mathrm{~mm}$. Tests were conducted for 30 days in filtered seawater that had a temperature of $30^{\circ} \mathrm{C}$ and was flowing nominally at $0.02 \mathrm{~m} / \mathrm{s}$.

Alloys 625 and C-276 did not suffer any attack. In contrast, Alloy 825 was attacked at 37 out of 120 available crevice sites, and Type 316 stainless steel at 33 . Depths of attack were comparable for Alloy 825 (0.25$2.42 \mathrm{~mm}$ ) and Type 316 stainless steel $(0.29-1.93 \mathrm{~mm})$, but initiation times were generally shorter for Type 316 stainless steel (24-102 h) than for Alloy $825(51-221 \mathrm{~h})$.

\subsubsection{Corrosion Resistance at Elevated Temperatures}

The corrosion resistance of Alloy C-276 in seawater at elevated temperatures remains good (Tables 39 
Table 38. Results of crevice corrosion tests on austenitic alloys (Hack 1983). Tests were performed in filtered natural seawater at $30^{\circ} \mathrm{C}$ for 30 days. There were a possible 120 crevice corrosion sites.

\begin{tabular}{|c|c|c|c|c|c|c|c|c|c|c|}
\hline \multirow[b]{2}{*}{ Material } & \multicolumn{5}{|c|}{ Approximate composition (wt\%) } & \multicolumn{2}{|c|}{$\begin{array}{c}\text { Number of } \\
\text { sites attacked }\end{array}$} & \multirow{2}{*}{$\begin{array}{l}\text { Number of } \\
\text { sides attacked }\end{array}$} & \multirow{2}{*}{$\begin{array}{l}\text { Depth of } \\
\text { attack (mm) }\end{array}$} & \multirow{2}{*}{$\begin{array}{c}\text { Initiation } \\
\text { time (h) }\end{array}$} \\
\hline & $\mathbf{C r}$ & $\mathbf{N i}$ & Mo & $\mathbf{M n}$ & $\mathbf{C u}$ & Per side & Total & & & \\
\hline $\begin{array}{l}\text { Type } 316 \\
\text { stainless steel }\end{array}$ & 17.5 & 10.7 & 2.4 & 1.6 & 0.3 & $1-13$ & 33 & 6 & $0.29-1.93$ & 24-102 \\
\hline $\begin{array}{l}904 \mathrm{~L} \\
20 \mathrm{Cb}-3\end{array}$ & $\begin{array}{l}20.5 \\
19.4\end{array}$ & $\begin{array}{l}24.7 \\
33.2\end{array}$ & $\begin{array}{l}4.7 \\
2.2\end{array}$ & $\begin{array}{l}1.5 \\
0.4\end{array}$ & $\begin{array}{l}1.6 \\
3.2\end{array}$ & $\begin{array}{l}0-13 \\
0-15\end{array}$ & $\begin{array}{l}36 \\
49\end{array}$ & $\begin{array}{l}5 \\
5\end{array}$ & $\begin{array}{l}0.14-0.74 \\
0.14-3.10\end{array}$ & $\begin{array}{l}51-365 \\
51-171\end{array}$ \\
\hline 825 & $\begin{array}{l}22.0 \\
22.2\end{array}$ & $\begin{array}{l}44.0 \\
46.8\end{array}$ & $\begin{array}{l}2.7 \\
5.8\end{array}$ & $\begin{array}{l}0.4 \\
1.5\end{array}$ & $\begin{array}{l}1.7 \\
1.8\end{array}$ & $\begin{array}{l}4-13 \\
0-2\end{array}$ & $\begin{array}{r}37 \\
6\end{array}$ & $\begin{array}{l}6 \\
4\end{array}$ & $\begin{array}{l}0.25-2.42 \\
0.02-0.87\end{array}$ & $\begin{array}{r}51-221 \\
365-673\end{array}$ \\
\hline G-3 & 22.8 & 43.7 & 7.0 & 0.8 & 1.8 & $0-2$ & 2 & 1 & $0.06-0.21$ & 102 \\
\hline 625 & 22.3 & 61.0 & 8.5 & 0.1 & & 0 & $\mathbf{0}$ & $\mathbf{0}$ & - & - \\
\hline C-276 & 15.5 & 54.7 & 15.5 & 0.5 & 0.1 & $\mathbf{0}$ & $\mathbf{0}$ & $\mathbf{0}$ & - & - \\
\hline
\end{tabular}

Table 39. Corrosion resistance of Alloy C-276 in seawater at elevated temperatures (Asphahani 1980b). (The nominal oxygen concentration in seawater is about 7 to 8 ppm.)

\begin{tabular}{cccccc}
\hline $\begin{array}{c}\text { Temperature } \\
\left({ }^{\circ} \mathbf{C}\right)\end{array}$ & $\mathbf{p H}$ & $\begin{array}{c}\text { Dissolved } \mathrm{O}_{2} \\
(\mathbf{m g} / \mathbf{l})\end{array}$ & $\begin{array}{c}\text { Velocity } \\
(\mathbf{m} / \mathbf{s})\end{array}$ & Crevice attack & $\begin{array}{c}\text { Test duration } \\
(\text { days })\end{array}$ \\
\hline 37 & 3.5 & 5200 & 2.7 & Not detected & 112 \\
35 & 3.5 & 28 & 2.7 & Not detected & 112 \\
35 & 7.7 & 28 & 2.7 & Not detected & 112 \\
63 & 7.7 & 28 & 1.4 & Not detected & 98 \\
82 & 7.7 & 28 & 2.7 & Not detected & 112 \\
107 & 7.7 & 28 & 2.7 & Not detected & 84 \\
\hline
\end{tabular}

and 40) (Asphahani 1980b). Crevice attack was not detected in flowing seawater at temperatures up to $107^{\circ} \mathrm{C}$ and $\mathrm{a} \mathrm{pH}$ of 7.7. The duration of the crevice-corrosion test was at least 84 days. In addition, uniform corrosion rates are low $(2.5 \mu \mathrm{m} / \mathrm{T})$ in slowly flowing seawater in the temperature range of 27 to $288^{\circ} \mathrm{C}$ (Asphahani 1980b). The uniform corrosion tests were rather short, ranging from 15 to 150 days.

\subsection{Deep-Seawater Corrosion}

Highly corrosion-resistant structural materials are required for use in the exploration and exploitation of ocean depths. The Ni-Cr-Mo alloys offer superior corrosion performance in comparison with stainless steels
Table 40. Corrosion resistance of Alloys C/C-276 in seawater at elevated temperatures (Asphahani 1980b).

\begin{tabular}{clcc}
\hline $\begin{array}{c}\text { Temperature } \\
\left({ }^{\circ} \mathrm{C}\right)\end{array}$ & $\begin{array}{c}\text { Velocity } \\
(\mathrm{m} / \mathrm{s})\end{array}$ & $\begin{array}{c}\text { Corrosion } \\
\text { rate } \\
(\mu \mathrm{m} / \mathrm{y})\end{array}$ & $\begin{array}{c}\text { Test } \\
\text { duration } \\
(\text { days })\end{array}$ \\
\hline 10 & 38 & 5.1 & 30 \\
27 & 0.3 & 2.5 & 150 \\
27 & 4 & 2.5 & 15 \\
163 & 0.15 & 2.5 & 54 \\
177 & 3 & 2.5 & 45 \\
288 & 3.3 & 2.5 & 24 \\
\hline
\end{tabular}


and copper alloys. They have exceptional resistance to pitting and crevice corrosion under deposits of marine organisms and during exposure to high-velocity water flow. Although these applications are not directly related to the conditions expected at a geologic repository, general trends in material properties may be useful in selecting the proper material for the container material.

Alloy C (the high-carbon version of Alloy C-276) has superior corrosion resistance to many alloys in deep-water ocean environments (Table 34) (Wheatfall 1967). Two separate tests were conducted at depths of $5640 \mathrm{ft}$. The salinity $(34,600 \mathrm{ppm})$, the $\mathrm{pH}(7.3)$, and the temperature $\left(2.6^{\circ} \mathrm{C}\right)$ were similar in both, but the oxygen concentration differed (1.19 ppm in the 123-day test and $2.14 \mathrm{ppm}$ in the 751-day test). Alloy C suffered no locaiized attack, and the uniform corrosion rates were low: $2.3 \mu \mathrm{m} / \mathrm{yr}$ and $0.09 \mu \mathrm{m} / \mathrm{yr}$ for test periods of 123 and 751 days, respectively. The lower corrosion rate for the longer test period was attributed to the higher oxygen content of the water in that environment (Wheatfall 1967). It is evident in Table 34 that Alloy C had better corrosion resistance than Type 304 stainless steel, $\mathrm{Cu}-\mathrm{Ni}(30)$, unalloyed copper, and Alloy 825. Type 304 stainless steel suffered severe LC in all of the environments, and Alloy 825 suffered severe crevice corrosion (it perforated) in the higher-oxygen environment. It should be mentioned that unalloyed titanium had corrosion rates similar to those of Alloy $\mathrm{C}$ and did not suffer LC.

The U.S. Naval Civil Engineering Laboratory conducted tests on several nickel alloys in a variety of deep ocean environments (Reinhart 1969). Some of the results of this study are shown in Table 41. No significant weight loss or any visible evidence of corrosion were found for Alloy 625 (tested 402 days) and Alloy C (tested up to 1064 days). Alloy X (tested up to 1,064 days) was corrosion-free except for one case of incipient crevice corrosion (test period of 197 days). The results for Alloy 825 are also shown in the table. This alloy suffered from crevice corrosion and incipient corrosion in many environments (Table 42). Alloy $C$ and Alloy 825 were also tested for SCC in deep ocean environments. Neither Alloy C (tested at up to $75 \%$ of yield stress for 751 days) nor Alloy 825 (tested at up to $75 \%$ of yield stress for 402 days) showed indications of stress corrosion cracks. Table 43 shows changes in the mechanical properties of Alloys $C$ and 825 under the different test conditions. For both alloys, changes in the tensile strength and yield stress were generally within $\pm 5 \%$. Alloy 825 also had small negative changes in elongation $(\leq 5.8 \%)$. In contrast, Alloy $\mathrm{C}$ was usually more ductile; under some conditions the elongation increased up to $18.1 \%$.

For deep-sea exposure a nickel-copper alloy (Alloy 400) had significantly higher corrosion rates than the alloys discussed previously (Table 44). Corrosion rates were generally in the range of 12.7 to $25.4 \mu \mathrm{m} / \mathrm{yr}$, although some higher rates did occur. Pitting and crevice corrosion were fairly common on this alloy.

Under some conditions, Alloy 400 exhibits good resistance to seawater corrosion (Reinhart 1969). This resistance was observed in the Atlantic Ocean (the above results were in the Pacific Ocean), where the oxygen concentration has been reported as $5.7 \mathrm{ml} / 1$. In the Atlantic Ocean, the corrosion rate was $5 \mu \mathrm{m} / \mathrm{yr}$ at about 100 days and became negligible at about 1,050 days. In addition, no fouling or pitting was observed on the specimens. The author speculated that the lack of fouling might have been due to current flow that was high enough to prevent stagnation.

\subsection{Brine Corrosion}

Brines are aggressive, concentrated salt solutions that typically have a low oxygen concentration. The addition of oxygen increases the corrosivity of these solutions. Corrosivity depends not only on chloride content but also on the cation species present. Magnesium ions appear to be the most aggressive cation.

A great deal of knowledge about how materials corrode in brines at elevated temperatures has been obtained from the harnessing of hydrothermal resources. Facilities have been built for producing energy and recovering minerals from these resources. The characteristics of the fluids vary among the geothermal reservoirs.

Hydrothermal systems are divided into several categories (Table 45) (Carter et al. 1980). When dry steam is produced from the geothermal rescrvoir, it is called vapor-dominated. Otherwise, the system is liquiddominated and is defined by its temperature: low, intermediate, or high. The Geysers Area in California is the major vapor-dominated system in the United States. The concentration of dissolved solids and chloride ions in the condensed steam is low, and the principal corrosive agent is sulfur as either sulfide or sulfate. Regarding liquid-dominated systems, Carter and coworkers (1990) state: 
Table 4.. Corrosion rates and types of corrosion for various alloys (Reinhart 1969).

\begin{tabular}{|c|c|c|c|c|c|c|}
\hline Alioy & Environment ${ }^{\mathrm{a}}$ & $\begin{array}{c}\text { Exposure } \\
\text { (days) }\end{array}$ & $\begin{array}{l}\text { Depth } \\
\text { (ft) }\end{array}$ & $\begin{array}{c}\text { Rate } \\
(\mu \mathrm{m} / \mathbf{y})\end{array}$ & $\begin{array}{c}\text { Crevice } \\
(\mu \mathrm{m})\end{array}$ & $\begin{array}{c}\text { Type of } \\
\text { corrosion }\end{array}$ \\
\hline 625 & $\mathbf{w}$ & 402 & 2340 & $<2.5$ & - & NC \\
\hline 625 & $\mathbf{w}$ & 402 & 2370 & $<2.5$ & - & NC \\
\hline 625 & $\mathbf{S}$ & 402 & 2370 & $<2.5$ & - & NC \\
\hline 825 & $\mathbf{W}$ & 123 & 5640 & $\mathbf{0}$ & - & NC \\
\hline 825 & $\mathbf{w}$ & 123 & 5640 & $<2.5$ & - & NC \\
\hline 825 & $\mathbf{S}$ & 123 & 5640 & $<2.5$ & - & NC \\
\hline 825 & $\mathbf{S}$ & 123 & 5640 & $<2.5$ & - & $\mathrm{NC}$ \\
\hline 825 & $\mathbf{w}$ & 403 & 6780 & 0 & - & NC \\
\hline 825 & $\mathbf{w}$ & 403 & 6780 & $<2.5$ & - & I C \\
\hline 825 & $\mathbf{S}$ & 403 & 6780 & $\mathbf{0}$ & - & NC \\
\hline 825 & $\mathbf{S}$ & 403 & 6780 & $<2.5$ & - & I C \\
\hline 825 & $\mathbf{w}$ & 751 & 5640 & 0 & 559 & C \\
\hline 825 & $\mathbf{W}$ & 751 & 5640 & $<2.5$ & - & NC \\
\hline 825 & $\mathbf{S}$ & 751 & 5640 & $<2.5$ & - & NC \\
\hline 825 & $\mathbf{w}$ & 1064 & 5300 & $<2.5$ & - & I C \\
\hline 825 & $\mathbf{S}$ & 1064 & 5300 & $<2.5$ & - & NC \\
\hline 825 & $\mathbf{W}$ & 197 & 2340 & 0 & - & NC \\
\hline 825 & $\mathbf{w}$ & 197 & 2340 & $<2.5$ & - & I C \\
\hline 825 & $\mathbf{S}$ & 197 & 2340 & O & 203 & C \\
\hline 825 & $\mathbf{S}$ & 197 & 2340 & $<2.5$ & - & NC \\
\hline 825 & $\mathbf{w}$ & 402 & 2370 & $<2.5$ & 381 & C \\
\hline 825 & $\mathbf{w}$ & 402 & 2370 & $<2.5$ & - & ET \\
\hline 825 & $\mathbf{w}$ & 402 & 2370 & $<2.5$ & - & I C \\
\hline $\begin{array}{l}825 \text {, welded } \\
135 \text { electrode }\end{array}$ & $\mathbf{w}$ & 402 & 2370 & $<2.5$ & - & d \\
\hline $\begin{array}{l}825 \text {, welded } \\
65 \text { electrode }\end{array}$ & $\mathbf{w}$ & 402 & 2370 & $<2.5$ & - & NC \\
\hline 825 & $\mathbf{S}$ & 402 & 2370 & $\mathbf{0}$ & 203 & C \\
\hline 825 & $\mathbf{S}$ & 402 & 2370 & $<2.5$ & - & NC \\
\hline 825 & $\mathbf{S}$ & 402 & 2370 & $<2.5$ & - & I C \\
\hline $825 S^{c}$ & $\mathbf{w}$ & 123 & 5640 & $<2.5$ & - & NC \\
\hline $825 S$ & $\mathbf{S}$ & 123 & 5640 & $<2.5$ & - & NC \\
\hline $825 S$ & $\mathbf{w}$ & 403 & 6780 & $<2.5$ & - & I C \\
\hline $825 S$ & $\mathbf{S}$ & 403 & 6780 & $<2.5$ & - & I C \\
\hline $825 S$ & $\mathbf{w}$ & 751 & 5640 & $<2.5$ & - & I C \\
\hline $825 S$ & $\mathbf{S}$ & 751 & 5640 & $<2.5$ & - & NC \\
\hline $825 S$ & $\mathbf{w}$ & 1064 & $\mathbf{5 3 0 0}$ & $<2.5$ & - & NC \\
\hline $825 S$ & $\mathbf{S}$ & 1064 & 5300 & $<2.5$ & 102 & C \\
\hline $825 S$ & $\mathbf{w}$ & 197 & 2340 & $<2.5$ & - & I C, I P \\
\hline $825 S$ & $\mathbf{S}$ & 197 & 2340 & $<2.5$ & - & I C, I P \\
\hline $825 S$ & $\mathbf{w}$ & 402 & 2370 & $<2.5$ & - & I C, I P \\
\hline $825 S$ & $\mathbf{S}$ & 402 & 2370 & $<2.5$ & - & I C, I P \\
\hline $825 \mathrm{Cb}$ & $\mathbf{W}$ & 123 & 5640 & $<2.5$ & - & NC \\
\hline $825 \mathrm{Cb}$ & $\mathbf{S}$ & 123 & 5640 & $<2.5$ & - & NC \\
\hline $825 \mathrm{Cb}$ & $\mathbf{W}$ & 403 & 6780 & $<2.5$ & - & I C \\
\hline $825 \mathrm{Cb}$ & $\mathbf{S}$ & 403 & 6780 & $<2.5$ & - & I C \\
\hline $825 \mathrm{Cb}$ & $\mathbf{W}$ & 751 & 5640 & $<2.5$ & - & I C \\
\hline
\end{tabular}


Table 41. (Continued.)

\begin{tabular}{|c|c|c|c|c|c|c|}
\hline Alloy & Environment" & $\begin{array}{c}\text { Exposure } \\
\text { (days) }\end{array}$ & $\begin{array}{l}\text { Depth } \\
\text { (ft) }\end{array}$ & $\begin{array}{c}\text { Rate } \\
(\mu \mathrm{m} / \mathrm{y})\end{array}$ & $\begin{array}{c}\text { Crevice } \\
(\mu \mathrm{m})\end{array}$ & $\begin{array}{c}\text { Type of } \\
\text { corrosion }^{b}\end{array}$ \\
\hline $825 \mathrm{Cb}$ & $\mathbf{S}$ & 751 & 5640 & $<2.5$ & - & NC \\
\hline $825 \mathrm{Cb}$ & $\mathbf{w}$ & 1064 & 5300 & $<2.5$ & - & NC \\
\hline $825 \mathrm{Cb}$ & $\mathbf{S}$ & 1064 & 5300 & $<2.5$ & - & NC \\
\hline $825 \mathrm{Cb}$ & $\mathbf{w}$ & 197 & 2340 & $<2.5$ & - & NC \\
\hline $825 \mathrm{Cb}$ & $\mathbf{S}$ & 197 & 2340 & $<2.5$ & - & NC \\
\hline $825 \mathrm{Cb}$ & $\mathbf{w}$ & 402 & 2370 & $<2.5$ & - & NC \\
\hline $825 \mathrm{Cb}$ & $\mathbf{S}$ & 402 & 2370 & $<2.5$ & - & I C \\
\hline $\mathbf{x}$ & $\mathbf{w}$ & 123 & 5640 & $<2.5$ & - & NC \\
\hline $\mathbf{X}$ & $\mathbf{S}$ & 123 & 5640 & $<2.5$ & - & NC \\
\hline $\mathbf{x}$ & $\mathbf{w}$ & 403 & 6780 & $<2.5$ & - & NC \\
\hline $\mathbf{x}$ & $\mathbf{S}$ & 403 & 6780 & $<2.5$ & - & NC \\
\hline $\mathbf{x}$ & $\mathbf{w}$ & 751 & 5640 & $<2.5$ & - & NC \\
\hline $\mathbf{X}$ & $\mathbf{S}$ & 751 & 5640 & $<2.5$ & - & NC \\
\hline $\mathbf{x}$ & $\mathbf{W}$ & 1064 & 5300 & $<2.5$ & - & SL ET \\
\hline $\mathbf{x}$ & $\mathbf{S}$ & 1064 & 5300 & $<2.5$ & - & NC \\
\hline $\mathbf{x}$ & $\mathbf{w}$ & 197 & 2340 & $<2.5$ & - & NC \\
\hline $\mathbf{x}$ & $\mathbf{S}$ & 197 & 2340 & $<2.5$ & - & I C \\
\hline $\mathbf{X}$ & $\mathbf{w}$ & 402 & 2370 & $<2.5$ & - & NC \\
\hline $\mathbf{x}$ & $\mathbf{S}$ & 402 & 2370 & $<2.5$ & - & NC \\
\hline C & $\mathbf{w}$ & 123 & 5640 & $<2.5$ & - & NC \\
\hline C & $\mathbf{w}$ & 123 & 5640 & $<2.5$ & - & NC \\
\hline C & $\mathbf{S}$ & 123 & 5640 & $<2.5$ & - & NC \\
\hline C & $\mathbf{S}$ & 123 & 5640 & $<2.5$ & - & NC \\
\hline C & $\mathbf{w}$ & 403 & 6780 & 0 & - & NC \\
\hline C & $\mathbf{w}$ & 403 & 6780 & $<2.5$ & - & NC \\
\hline $\mathbf{C}$ & $\mathbf{S}$ & 403 & 6780 & 0 & - & NC \\
\hline C & $\mathbf{S}$ & 403 & 6780 & $<2.5$ & - & NC \\
\hline C & $\mathbf{W}$ & 751 & 5640 & 0 & - & NC \\
\hline C & $\mathbf{W}$ & 751 & 5640 & $<2.5$ & - & NC \\
\hline C & $\mathbf{S}$ & 751 & 5640 & 0 & - & NC \\
\hline C & $\mathbf{S}$ & 751 & 5640 & $<2.5$ & - & NC \\
\hline C & $\mathbf{w}$ & 1064 & 5300 & O & - & NC \\
\hline C & $\mathbf{w}$ & 1064 & 5300 & $<2.5$ & - & NC \\
\hline C & $\mathbf{S}$ & 1064 & 5300 & 0 & - & NC \\
\hline C & $\mathbf{S}$ & 1064 & 5300 & $<2.5$ & - & NC \\
\hline C & $\mathbf{W}$ & 197 & 2340 & 0 & - & NC \\
\hline C & $\mathbf{w}$ & 197 & 2340 & $<2.5$ & - & NC \\
\hline C & $\mathbf{S}$ & 197 & 2340 & 0 & - & NC \\
\hline C & $\mathbf{S}$ & 197 & 2340 & $<2.5$ & - & NC \\
\hline C & $\mathbf{W}$ & 402 & 2370 & 0 & - & NC \\
\hline C & $\mathbf{W}$ & 402 & 2370 & $<2.5$ & - & NC \\
\hline C & $\mathbf{S}$ & 402 & 2370 & 0 & - & NC \\
\hline C & $\mathbf{S}$ & 402 & 2370 & $<2.5$ & - & NC \\
\hline
\end{tabular}

a, specimen was exposed on the sides of the STU in seawater; $S$, specimen was exposed at the base of the submersible test unit (STU), which was partially embedded in bottom sediments.

b Symbols for type of corrosion: C, crevice; ET, etched; I, incipient; NC, no visible corrosion; P, pitting; SL, slight.

c $S$ indicates sensitization for $1 \mathrm{~h}$ at $1200^{\circ} \mathrm{F}$.

d One end of the weld was corroded. 
Table 42. Results of SCC tests of Alloys $\mathrm{C}$ and 825 in deep ocean environments (Reinhart 1969).

\begin{tabular}{|c|c|c|c|c|c|c|}
\hline Alloy & $\begin{array}{l}\text { Stress } \\
\text { (ksi) }\end{array}$ & $\begin{array}{l}\text { Percent of } \\
\text { yield stress }\end{array}$ & $\begin{array}{c}\text { Exposure } \\
\text { (days) }\end{array}$ & $\begin{array}{l}\text { Depth } \\
\text { (ft) }\end{array}$ & $\begin{array}{l}\text { Number of } \\
\text { specimens }\end{array}$ & $\begin{array}{l}\text { Number } \\
\text { that failed }\end{array}$ \\
\hline C & 21.0 & 35 & 123 & 5640 & 3 & 0 \\
\hline C & 30.0 & 50 & 123 & 5640 & 3 & 0 \\
\hline C & 45.0 & 75 & 123 & 5640 & 3 & 0 \\
\hline C & 21.0 & 35 & 403 & 6780 & 2 & 0 \\
\hline C & 30.0 & 50 & 403 & 6780 & 2 & 0 \\
\hline C & 45.0 & 75 & 403 & 6780 & 2 & 0 \\
\hline C & 21.0 & 35 & 751 & 5640 & 3 & 0 \\
\hline C & 30.0 & 50 & 751 & 5640 & 3 & 0 \\
\hline C & 45.0 & 75 & 751 & 5640 & 3 & 0 \\
\hline C & 21.0 & 35 & 197 & 2340 & 3 & 0 \\
\hline C & 30.0 & 50 & 197 & 2340 & 3 & 0 \\
\hline C & 45.0 & 75 & 197 & 2340 & 3 & 0 \\
\hline C & 30.0 & 50 & 402 & 2370 & 3 & 0 \\
\hline C & 45.0 & 75 & 402 & 2370 & 3 & 0 \\
\hline 825 & 25.7 & 50 & 402 & 2370 & 3 & 0 \\
\hline 825 & 38.5 & 75 & 402 & 2370 & 3 & 0 \\
\hline
\end{tabular}

Table 43. Changes in mechanical properties of Alloys 825 and $C$ due to corrosion in deep ocean environments (Reinhart 1969).

\begin{tabular}{|c|c|c|c|c|c|c|c|}
\hline \multirow[b]{2}{*}{$\begin{array}{l}\text { Depth } \\
\text { (ft) }\end{array}$} & \multirow[b]{2}{*}{$\begin{array}{c}\text { Exposure } \\
\text { (days) }\end{array}$} & \multicolumn{3}{|c|}{ Original properties } & \multicolumn{3}{|c|}{ Percent change } \\
\hline & & $\begin{array}{l}\text { Ultimate tensile } \\
\text { strength } \\
\text { (ksi) }\end{array}$ & $\begin{array}{l}\text { Yield stress } \\
\quad(\mathrm{ksi})\end{array}$ & $\begin{array}{c}\text { Elongation } \\
(\%)\end{array}$ & $\begin{array}{l}\text { Ultimate } \\
\text { tensile } \\
\text { strength }\end{array}$ & $\begin{array}{l}\text { Yield } \\
\text { stress }\end{array}$ & Elongation \\
\hline Alloy 825 & & 108.1 & 52.3 & 37.8 & & & \\
\hline 5640 & 123 & & & & 0.4 & 3.8 & 0.0 \\
\hline 6780 & 403 & & & & 0.3 & 2.7 & -3.5 \\
\hline 5640 & 751 & & & & 1.5 & 4.9 & -2.6 \\
\hline 2340 & 197 & & & & 0.4 & 3.9 & -5.8 \\
\hline 2370 & 402 & & & & 0.7 & 3.9 & -3.3 \\
\hline Alloy C & & 120.8 & 60.0 & 43.0 & & & \\
\hline 5640 & 123 & & & & 3.0 & 4.5 & -0.5 \\
\hline 6780 & 403 & & & & 4.7 & 1.4 & 15.1 \\
\hline 5640 & 751 & & & & 4.4 & -0.2 & 14.8 \\
\hline 5300 & 1064 & & & & 3.4 & -7.4 & 14.9 \\
\hline 2340 & 197 & & & & 3.1 & -0.5 & 18.1 \\
\hline 2370 & 402 & & & & 3.2 & 3.0 & 11.9 \\
\hline
\end{tabular}


Table 44. Corrosion rates and types of corrosion of Alloy 400 under deep sea exposure (Reinhart 1969).

\begin{tabular}{|c|c|c|c|c|c|c|}
\hline Alloy & Environment" & $\begin{array}{l}\text { Exposure } \\
\text { (days) }\end{array}$ & $\begin{array}{l}\text { Depth } \\
\text { (ft) }\end{array}$ & $\begin{array}{c}\text { Rate } \\
(\mu \mathrm{m} / \mathbf{y})\end{array}$ & $\begin{array}{c}\text { Crevice } \\
(\mu \mathrm{m})\end{array}$ & $\begin{array}{l}\text { Type of } \\
\text { corrosion }^{b}\end{array}$ \\
\hline 400 & $\mathbf{w}$ & 123 & 5640 & 20.3 & None & $\mathbf{U}$ \\
\hline 400 & $\mathbf{w}$ & 123 & 5640 & 10.2 & None & $\mathbf{U}$ \\
\hline 400 & $\mathbf{S}$ & 123 & 5640 & 12.7 & None & $\mathbf{U}$ \\
\hline 400 & $\mathbf{S}$ & 123 & 5640 & 10.2 & 127 & $\mathbf{C}, \mathbf{U}$ \\
\hline 400 & $\mathbf{w}$ & 403 & 6780 & 12.7 & 254 & P: $510 \mu \mathrm{m}, 371 \mathrm{a} ; \mathrm{E}$ \\
\hline 400 & $\mathbf{w}$ & 403 & 6780 & 20.3 & 1020 (PR) & $\mathbf{C}, \mathbf{U}$ \\
\hline 400 & $\mathbf{S}$ & 403 & 6780 & 10.2 & 254 & $C ; P: 457 \mu \mathrm{m}, 254 a ; E$ \\
\hline 400 & $\mathbf{S}$ & 403 & 6780 & 2.5 & 51 & $\mathbf{C}, \mathbf{U}$ \\
\hline 400 & $\mathbf{w}$ & 751 & 5640 & 25.4 & 1143 & C; P: $1143 \mu \mathrm{m}, 914 a ; E$ \\
\hline 400 & $\mathbf{w}$ & 751 & 5640 & 78.7 & 1020 (PR) & $\mathbf{C}, \mathbf{P}$ \\
\hline 400 & $\mathbf{S}$ & 751 & 5640 & 33.0 & 1020 (PR) & $\mathbf{C}$ \\
\hline 400 & $\mathbf{w}$ & 1064 & 5300 & 12.7 & 152 & C \\
\hline 400 & $\mathbf{w}$ & 1064 & 5300 & 20.3 & Yes & $\mathbf{C}, \mathbf{E}$ \\
\hline 400 & $\mathbf{w}$ & 1064 & 5300 & 27.9 & Yes & $\mathbf{C}, \mathbf{E}$ \\
\hline 400 & $\mathbf{w}$ & 1064 & 5300 & 12.7 & 1020 (PR) & $\mathbf{C , P}$ \\
\hline 400 & $\mathbf{S}$ & 1064 & 5300 & 15.2 & 3180 (PR) & C; P: $1194 \mu \mathrm{m}, 890 \mathrm{a}$ \\
\hline 400 & $\mathbf{S}$ & 1064 & 5300 & 15.2 & 1020 (PR) & $\mathbf{C}, \mathbf{P R}$ \\
\hline 400 & $\mathbf{W}$ & 123 & 2500 & 10.2 & None & $\mathbf{U}$ \\
\hline 400 & $\mathbf{w}$ & 197 & 2340 & 10.2 & 279 & C; P: $254 \mu \mathrm{m}, 241 \mathrm{a}$ \\
\hline $\begin{array}{l}400 \\
400\end{array}$ & $\begin{array}{l}\mathbf{w} \\
\mathbf{S}\end{array}$ & $\begin{array}{l}197 \\
197\end{array}$ & $\begin{array}{l}2340 \\
2340\end{array}$ & $\begin{array}{r}10.2 \\
7.6\end{array}$ & $\begin{array}{l}178 \\
\text { None }\end{array}$ & $\begin{array}{l}\mathbf{C} \\
\mathbf{U}\end{array}$ \\
\hline 400 & $\mathbf{S}$ & 197 & 2340 & 5.1 & 102 & C \\
\hline 400 & $\mathbf{w}$ & 402 & 2370 & 12.7 & None & P: $356 \mu \mathrm{m}$ \\
\hline 400 & $\mathbf{w}$ & 402 & 2370 & 7.6 & None & P: $510 \mu \mathrm{m}, 447 \mathrm{a}$ \\
\hline 400 & $\mathbf{w}$ & 402 & 2370 & 20.3 & 1020 (PR) & $\mathbf{C}, \mathbf{P}$ \\
\hline 400 & $\mathbf{S}$ & 402 & 2370 & 5.1 & None & I P \\
\hline 400 & $\mathbf{S}$ & 402 & 2370 & 7.6 & None & $\mathbf{E}, \mathbf{I} \mathbf{P}$ \\
\hline 400 & $\mathbf{S}$ & 402 & 2370 & 2.5 & None & ET \\
\hline $\begin{array}{l}400, \text { welded } \\
130 \text { electrode }\end{array}$ & $\mathbf{w}$ & 402 & 2370 & 12.7 & None & I P \\
\hline $\begin{array}{l}400, \text { welded } \\
180 \text { electrode }\end{array}$ & $\mathbf{W}$ & 402 & 2370 & 12.7 & None & I P \\
\hline $\begin{array}{l}\text { 400, welded } \\
\text { metal } 60\end{array}$ & $\mathbf{w}$ & 402 & 2370 & 10.2 & None & I P \\
\hline $\begin{array}{l}400, \text { welded } \\
\text { metal } 60\end{array}$ & $\mathbf{S}$ & 402 & 2370 & 10.2 & None & $\mathbf{E}$ \\
\hline
\end{tabular}

a $W$, specimen was exposed on the sides of the STU in seawater; S, specimen was exposed in the base of the STU, partially embedded in bottom sediments.

b Symbols for type of corrosion: C, crevice; E, edge; ET, etched; I, incipient; P, pitting; PR, perforation; U, uniform. Numbers indicate depth in $\mu \mathrm{m}$, l.e., $20 \mu \mathrm{m}=20 \mu \mathrm{m}$ maximum; $14.6 \mathrm{a}=14.6 \mu \mathrm{m}$ average.

c $S$ indicates sensitization for $1 \mathrm{~h}$ at $1200^{\circ} \mathrm{F}$.

d One end of the weld was corroded. 
Table 45. Characteristics of hydrothermal systems (Carter et al. 1980).

\begin{tabular}{lllc}
\hline \multicolumn{1}{c}{ System } & $\begin{array}{c}\text { Temperature } \\
\left({ }^{\circ} \mathrm{C}\right)\end{array}$ & $\begin{array}{c}\text { Total } \\
\text { dissolved } \\
\text { solids } \\
(\mathrm{ppm})\end{array}$ & $\mathbf{p H}$ \\
\hline Vapor-dominated & 240 & $<20(\mathrm{Cl})$ & $\mathbf{7 . 3 - 8 . 2}$ \\
Liquid-dominated & & & \\
High-temp & $>150$ & $1,000-345,000$ & $4.0-9.0$ \\
Intermediate-temp & $90-150$ & $800-55,000$ & $6.9-9.3$ \\
Low-temp & $<90$ & $40-1000$ & $8.1-9.8$ \\
\hline
\end{tabular}

Liquid-dominated hydrothermal systems include low-, intermediate-, and high-temperature resources. The brines in these liquid-dominated systems contain primarily chlorides of the alkali and alkaline earth metals. Salinities tend to increase with temperature. In California, Salton Sea geothermal brines typically contain more than 250,000 ppm dissolved solids and consequently readily form scale and mineral deposits in process equipment. The $\mathrm{pH}$ of the brines tends to decrease with increasing temperature, the high-temperature brines being most acidic. However, when dissolved gases such as $\mathrm{CO}_{2}$ and $\mathrm{H}_{2} \mathrm{~S}$ are stripped from the brine, the acidity drops appreciably. Other gases in the brine that affect corrosivity are methane, hydrogen, and ammonia. Oxygen can enter the brine during process operations.

Geothermal reservoirs can produce brines that are among the most corrosive naturally occurring fluids (Carter and McCawley 1978). For example, the geothermal fields of the Imperial Valley of California produce brines containing 3 to $32 \%$ total dissolved solids and have temperatures of 130 to $250^{\circ} \mathrm{C}$. The high salinities and temperatures make these brines extremely corrosive. In addition, these brines produce a variety of scales that complicate the corrosion processes. Coherent scales may suppress corrosion, whereas unconsolidated or porous scales may promote LC (Carter et al. 1980).

Table 46 shows corrosion data obtained from deaerated $28-w t \%$ brine at $232^{\circ} \mathrm{C}$ ( 15 day test). Alloy 625 , Alloy C-276, and some of the titanium alloys ( $\mathrm{Ti}$ $2 \mathrm{Ni}$ and $\mathrm{Ti}-10 \mathrm{~V}$ ) had the best overall corrosion resistance. These alloys had undetectable general corrosion, did not pit, and did not show SCC. (However, slight crevice corrosion was found in Alloy C-276 in a 30-day test.) Type 316L stainless steel suffered both crevice corrosion and SCC. Alloy 400 and $\mathrm{Cu}-30 \mathrm{Ni}$ both had high general corrosion rates but no crevice corrosion or SCC. Alloy G, which is similar to Alloy 825, was susceptible to crevice corrosion. Pure titanium did not perform well, as it was susceptible to pitting and crevice corrosion.

In aerated brines, the $\mathrm{Ni}-\mathrm{Cr}$-Mo alloys and the titanium alloys had superior corrosion resistance (Carter and Cramer 1974). Tests were run in 3- and 28-wt\% brine at $105^{\circ} \mathrm{C}$ and $1 \mathrm{~atm}$ for 15 days (Table 47). Alloys 625 and C-276 and the titanium alloys had very low general corrosion rates and exhibited no evidence of crevice corrosion. Alloy 400 and $\mathrm{Cu}-30 \mathrm{Ni}$ were susceptible to both general corrosion and crevice corrosion. Pure copper had high general corrosion. Type $316 \mathrm{~L}$ stainless steel and pure titanium suffered crevice corrosion in both brines, and Alloy $\mathrm{G}$ only in the highconcentration brine.

In geothermal waters from Utah, the corrosion resistance of Alloy 625 was superior to that of Type 316L stainless steel (Hong and Pitt 1983). These alloys were tested for pitting resistance and general corrosion rates in the temperature range of 25 to $90^{\circ} \mathrm{C}$. (The Utah geothermal water contained 916 and $615 \mathrm{mg} / \mathrm{l}$ of Cl${ }^{-}$ and $\mathrm{SO}_{4}{ }^{2-}$, respectively, and had a pH of 6.6 at $76^{\circ} \mathrm{C}$.) Type $316 \mathrm{~L}$ stainless steel formed pits at temperatures above $40^{\circ} \mathrm{C}$, and Alloy 625 was strongly resistant to pitting corrosion at all temperatures tested. It is interesting that for Type 316L stainless steel, pit density and depth both decreased with increasing temperature above $60^{\circ} \mathrm{C}$. General corrosion rates of about $25 \mu \mathrm{m} / \mathrm{yr}$ were determined for both alloys. Maximums in the corrosion rates were found at 50 and $60^{\circ} \mathrm{C}$ for Alloy 625 and Type 316L stainless steel, respectively.

Braithwaite and Molecke (1980) performed tests to determine the corrosion resistance of various alloys to oxygenated brine (Brine A) and seawater. The compositions of these solutions are given in Table 48. The tests were performed by Sandia National Laboratories, Albuquerque, to determine the compatibility of materials with bedded-salt and subseabed environments. 
Table 46. Corrosion data from tests conducted in deaerated Niland brine (28 wt \%) at $232^{\circ} \mathrm{C}$ for 15 days (Carter and Cramer 1974).

\begin{tabular}{llcc}
\hline \multicolumn{1}{c}{ Alloy } & $\begin{array}{c}\text { General } \\
\text { corrosion } \\
(\mu \mathrm{m} / \mathrm{yr})\end{array}$ & $\begin{array}{c}\text { Crevice } \\
\text { corrosion }\end{array}$ & SCC \\
\hline Type 316L stainless steel & 0 & 2 & Yes \\
20 & 7.6 & 3 & Yes \\
400 & 503 & 1 & No \\
625 & 0 & 1 & No \\
G & 2.5 & 2 & No \\
C-276 & 0 & 1 & No \\
Cu/Ni 70/30 & 386 & 1 & No \\
Titanium & 7.6 (pittingb) & 4 & No \\
Ti-1.7W & 0 & 1 & No \\
Ti-2Ni & 2.5 & 3 & No \\
Ti-10V & 0 & 1 & No \\
\hline
\end{tabular}

- 1, not detected; 2 , slight (<25 $\mu \mathrm{m} / \mathrm{yr}) ; 3$, moderate (<127 $\mu \mathrm{m} / \mathrm{gr}) ; 4$ severe ( $>127 \mu \mathrm{m} / \mathrm{yr})$.

b Pitting, 51 to $152 \mu \mathrm{m}$.

Table 47. Corrosion data from tests conducted at $105^{\circ} \mathrm{C}$ and 1 atm for 15 days in aerated solutions (Carter and Cramier 1974).

\begin{tabular}{|c|c|c|c|c|}
\hline \multirow[b]{2}{*}{ Alloy } & \multicolumn{2}{|c|}{$\begin{array}{c}\text { General corrosion } \\
(\mu \mathrm{m} / \mathbf{y r})\end{array}$} & \multicolumn{2}{|c|}{ Crevice corrosion ${ }^{a}$} \\
\hline & $\begin{array}{l}\text { Holtville } \\
\text { brine } \\
\text { (3wt\%) }\end{array}$ & $\begin{array}{c}\text { Niland } \\
\text { brine } \\
(28 w t \%)\end{array}$ & $\begin{array}{c}\text { Holtville } \\
\text { brine } \\
(3 \text { wt\%) }\end{array}$ & $\begin{array}{c}\text { Niland } \\
\text { brine } \\
(28 w t \%)\end{array}$ \\
\hline Type 316L stainless steel & $\mathbf{0}$ & 102 & 2 & 6 \\
\hline 20 & 5.08 & $\mathbf{5 1}$ & 1 & 5 \\
\hline 400 & 2.5 & 94 & 4 & 5 \\
\hline 625 & 64 & $\mathbf{0}$ & 1 & 1 \\
\hline G & 2.5 & 2.5 & 1 & 4 \\
\hline C-276 & 2.5 & $\mathbf{0}$ & 1 & 1 \\
\hline Copper & 1603 & 318 & - & 1 \\
\hline $\mathrm{Cu} / \mathrm{Ni} \mathbf{7 0 / 3 0}$ & 455 & 147 & - & 4 \\
\hline Titanium & 0 & 0 & 2 & 2 \\
\hline $\mathrm{Ti}-1.7 \mathrm{~W}$ & $\mathbf{0}$ & 0 & 1 & 1 \\
\hline Ti-2Ni & 2.5 & $\mathbf{0}$ & - & 1 \\
\hline Ti-10V & 0 & 0 & - & 1 \\
\hline
\end{tabular}

a 1 , not detected; 2 , very slight $(<2.5 \mu \mathrm{m} / \mathrm{yr}) ; 3$, slight $(<25.4 \mu \mathrm{m} / \mathrm{yr}) ; 4$, moderate ( $<127 \mu \mathrm{m} / \mathrm{gr}) ; 5$, severe $(<1270 \mu \mathrm{m} / \mathrm{yr})$; and 6 , very severe $(>1270 \mu \mathrm{m} / \mathrm{yr})$. 
Table 48. Representative solution compositions (major ions) for the corrosion tests whose results are given in Tables 49 and 50 (Braithwaite and Molecke 1980).

\begin{tabular}{lcrc}
\hline \multicolumn{1}{c}{ Ion } & $\begin{array}{c}\text { Seawater } \\
(\mathrm{ppm})\end{array}$ & $\begin{array}{c}\text { Brine A } \\
(\mathrm{ppm})\end{array}$ & $\begin{array}{c}\text { Brine B } \\
(\mathrm{ppm})\end{array}$ \\
\hline $\mathrm{Na}^{+}$ & 10,651 & 42,000 & 115,000 \\
$\mathrm{~K}^{+}$ & 380 & 30,000 & 15 \\
$\mathrm{Mg}^{2+}$ & 1,272 & 35,000 & 10 \\
$\mathrm{Ca}^{2+}$ & 400 & 600 & 900 \\
$\mathrm{Sr}^{2+}$ & 13 & 5 & 15 \\
$\mathrm{Cr}^{-}$ & 18,980 & 190,000 & 175,000 \\
$\mathrm{SO}_{4}^{2-}$ & 884 & 3,500 & 3,500 \\
$\mathrm{I}^{-}$ & 0.05 & 10 & 10 \\
$\mathrm{HCO}_{3}-$ & 146 & 700 & 10 \\
$\mathrm{Br}^{-}$ & 65 & 400 & 400 \\
$\mathrm{BO}_{3}$ & - & 1200 & 10 \\
$\mathrm{pH}^{-}$ & 8.1 & 6.5 & 6.5 \\
Total dissolved & $35 \mathrm{~g} / 1$ & $306 \mathrm{~g} / 1$ & $297 \mathrm{~g} / 1$ \\
solids & & & \\
\hline
\end{tabular}

The environments used in the tests were extremely aggressive: the temperature was $250^{\circ} \mathrm{C}$ and the total pressure was $69 \mathrm{~atm}$. Ti Gr-12 performer the best in these solutions; corrosion rates were about $0.5 \mu \mathrm{m} / \mathrm{yr}$ in both the brine and seawater (Table 49). Alloy C-276 coupons suffered both pitting and crevice corrosion in

Table 49. Corrosion rates of selected alloys in oxygenated solutions (Braithwaite and Molecke 1980). ( $T=250^{\circ} \mathrm{C}, P=7 \mathrm{MPa}$, and $t=14$ days.)

\begin{tabular}{lcc}
\hline \multicolumn{1}{c}{ Alloy } & $\begin{array}{c}\text { Brine } A \\
(\mu \mathrm{m} / \mathrm{yr})\end{array}$ & $\begin{array}{c}\text { Seawater } \\
(\mu \mathrm{m} / \mathrm{yr})\end{array}$ \\
\hline 1018 mild steel & 7,000 & 11,000 \\
Copper & 1,200 & 5,000 \\
Lead & 1,200 & 1,000 \\
$90-10$ cupronickel & 400 & 700 \\
Ebrite 26-1 & 240 & - \\
20 Cb-3 & $100^{\mathrm{b}}$ & - \\
600 & - & 100 \\
C-276 & $60^{\mathrm{c}}$ & $260^{\mathrm{c}}$ \\
Ti Gr-12 & 0.4 & 0.6 \\
\hline
\end{tabular}

$\left(\mathrm{O}_{2}\right)=600 \mathrm{ppm}$ in Brine A and $1750 \mathrm{ppm}$ in seawater.

b Crevice corrosion.

c Pitting and crevice corrosion. these environments. It is interesting that he autcclaves used in the tests were made of Alloy $\mathrm{C}-\llcorner, 16$ and did not exhibit LC.

In conjunction with the rests in oxygenated solutions, tests were performed in deoxygenated solutions. The corrosion resistance of most of the alloys was better in the deoxygenated solutions (Table 50). However, the corrosion rates of Ti Gr-12 were greater in the deoxygenated solutions; these rates were nevertheless lower than those of the other alloys tested except for Zircaloy-2. In addition, Alloy 625 suffered pitting corrcsion in deoxygenated seawater.

Table 50. Corrosion rates of various alloys in deoxygenated solution (Braithwaite and Molecke 1980). $\left(T=250^{\circ} \mathrm{C}, P=5 \mathrm{MPa}\right.$, and $t=28$ days.)

\begin{tabular}{lrcc}
\hline \multicolumn{1}{c}{ Alloy } & $\begin{array}{r}\text { Brine A } \\
(\mu \mathrm{m} / \mathrm{yr})\end{array}$ & $\begin{array}{c}\text { Brine B } \\
(\mu \mathrm{m} / \mathrm{yr})\end{array}$ & $\begin{array}{c}\text { Seawater } \\
(\mu \mathrm{m} / \mathrm{yr})\end{array}$ \\
\hline 1018 mild steel $\left(2^{\circ} \mathrm{C}\right)$ & 30 & 30 & - \\
1018 mild steel $\left(7^{\circ} \mathrm{C}\right)$ & 70 & 36 & - \\
1018 mild steel & 1700 & 70 & 400 \\
Corten A steel & 900 & 50 & 200 \\
2 1/4 Cr - 1 Mo steel & $1000^{2}$ & $100^{2}$ & 200 \\
Lead & 500 & 300 & 300 \\
Copper & 70 & 50 & 50 \\
Naval brass & 1000 & - & 1000 \\
$90-10$ cupronickel & 140 & - & 70 \\
Type 304L & 18 & 10 & 6 \\
stainless steel & & & \\
Type 316L & 15 & - & 5 \\
stainless steel & & & \\
Nitronic 50 & 8 & - & 3 \\
$20 \mathrm{Cb}-3$ & 7 & - & 5 \\
Ebrite 26-1 & 16 & - & 5 \\
400 & 30 & - & 100 \\
825 & 6 & - & 4 \\
600 & 9 & 7 & 5 \\
625 & 5 & 1 & $12^{\mathrm{b}}$ \\
C-276 & 7 & - & 1.5 \\
Zircaloy-2 & 1 & - & - \\
Titanium C.P. & 14 & - & 12 \\
Ti Gr-12 & 3 & - & 1 \\
\hline & & & \\
\hline
\end{tabular}

- Crevice corrosion.

i Piting corrosion. 
The corrosiveness of a solution was dependent on the cation species present (Braithwaite and Molecke 1980). Compare the compositions of brines and seawater tested (Table 48) with the corrosion results in Table 50. The $\mathrm{Na} / \mathrm{K} / \mathrm{Mg}$ chloride brine was the most aggressive while the $\mathrm{NaCl}$ brine was the least aggressive. An intermediate level of aggressiveness was observed with seawater. (The two brine solutions had a chloride concentration of about $190,000 \mathrm{ppm}$, which is an order of magnitude higher than that of seawater.) The authors suggested that the aggressiveness of the $\mathrm{Na} / \mathrm{K} / \mathrm{Mg}$ and seawater solutions was due to the decrease in the $\mathrm{pH}$ of these solutions near the test temperature $\left(250^{\circ} \mathrm{C}\right)$.

\subsection{Summary}

In aqueous chloride solution, the $\mathrm{Ni}-\mathrm{Cr}$-Mo alloys have significantly superior corrosion resistance com- pared with Type 300 series stainless steels, copper alloys, nickel-copper alloy (Alloy 400), and the Fe-Ni$\mathrm{Cr}$-Mo alloys (Alloys $\mathrm{G}$ and 825 ). Titarium alloys and $\mathrm{Ni}-\mathrm{Cr}$-Mo alloys have similar resistances to corrosion. Their superior corrosion resistance includes resistance to general corrosion, crevice corrosion, pitting, and SCC. General corrosion rates in seawater are usually less than $1 \mu \mathrm{m} / \mathrm{yr}$, the detection limit, and these alloys are usually not susceptible to pitting, crevice corrosion, or SCC. In hot brines, general corrosion rates are less than $3 \mu \mathrm{m} / \mathrm{yr}$, and again the $\mathrm{Ni}-\mathrm{Cr}$-Mo alloys are not susceptible to pitting, crevice corrosion, or SCC.

Data on the Ni-Cr-Mo alloys in aqueous salt solutions were primarily obtained from tests on Alloy 625 and Alloy C/C-276. Data on corrosion of other alloys in seawater and brines, such as Alloys $C-4$ and $C-22$, were not found. On the basis of their composition, however, these alloys would be expected to have similar performance in these solutions.

\section{$5 \mathrm{SCC}$ in Hydrogen Environments}

Numerous studies have been performed on the hydrogen embrittlement (HE) of the $\mathrm{Ni}-\mathrm{Cr}$-Mo alloys because of interest in the failure of these alloys in sourgas wells. These wells can be $1000 \mathrm{~m}$ deep and contain aggressive aqueous $\mathrm{H}_{2} \mathrm{~S}-\mathrm{NaCl}$ environments at bottomhole pressures of 140 to $210 \mathrm{MPa}(20,000$ to 30,000 psi) and temperatures of 200 to $300^{\circ} \mathrm{C}$ (Fiori and Kargol 1981). Annealed alloys are extremely resistant to HE in this environment but, unfortunately, they lack adequate strength for the structural application. The alloys are strengthened by cold working, but this process makes them susceptible to HE in sour-gas environments when they are galvanically coupled to a less noble material. The particular type of HE that causes these alloys to fail in sour-gas environments is called hydrogen stress cracking.

Fortunately, the structural requirements of the canisters for the Yucca Mountian Site Characterization Project are such that strengthening of the alloys is noi required, i.e., the $\mathrm{Ni}-\mathrm{Cr}$-Mo alloys could be used in the annealed condition, which is resistant to HE. The roomtemperature strengths of annealed $\mathrm{Ni}-\mathrm{Cr}$-Mo alloys are comparable to the annealed strengths of candidate austenitic alloys (Types 304L and 316L stainless steels and Allov 825) (Table 51). Yield surengths of the $\mathrm{Ni}-\mathrm{Cr}_{-}-$ Mo alloys are in the range of 40 to $70 \mathrm{ksi}$, and the ultimate tensile strengths are in the range of 100 to $140 \mathrm{ksi}$.
Table 51. Typical annealed mechanical propertivs of some selected materials.

\begin{tabular}{|c|c|c|c|}
\hline Alloy & $\begin{array}{c}\text { Yield } \\
\text { stress } \\
\text { ksi } \\
(\mathbf{M P a})\end{array}$ & $\begin{array}{l}\text { Ultimate } \\
\text { tensile } \\
\text { strength ksi } \\
\text { (MPa) }\end{array}$ & $\begin{array}{c}\text { Elongation } \\
(\%)\end{array}$ \\
\hline $\begin{array}{l}\text { Type } 304 \\
\text { stainless steel }\end{array}$ & $33(227)$ & $89(620)$ & 71 \\
\hline $\begin{array}{l}\text { Type } 316 \\
\text { stainless steel }\end{array}$ & $34(234)$ & $85(586)$ & 61 \\
\hline $400^{b}$ & $37(255)$ & $80(552)$ & 48 \\
\hline $825^{b}$ & $50(345)$ & $95(655)$ & 40 \\
\hline $\mathbf{G}^{\mathbf{b}}$ & $46(317)$ & $102(703)$ & 61 \\
\hline $625^{b}$ & $70(483)$ & $135(931)$ & 42 \\
\hline$C-276^{b}$ & $42(290)$ & $100(689)$ & 56 \\
\hline$C-4^{b}$ & $53(365)$ & $113(779)$ & 55 \\
\hline$C-22^{c}$ & $59(407)$ & $116(800)$ & 57 \\
\hline
\end{tabular}


Table 52. Results of tests on C-ring specimens of Alloys C-276 and 625. The alloys were tested in roomtemperature NACE solution ${ }^{2}$ without steel couples (Kane et al. 1977).

\begin{tabular}{ccccccc}
\hline Material & $\begin{array}{c}\text { Percent } \\
\text { cold work }\end{array}$ & $\begin{array}{c}\text { Aging temp } \\
\left({ }^{\circ} \mathbf{C}\right)\end{array}$ & $\begin{array}{c}\text { Aging time } \\
(\mathbf{h})\end{array}$ & $\begin{array}{c}\text { Applied stress } \\
(\% \text { transverse } \\
\text { yield stress) }\end{array}$ & $\begin{array}{c}\text { Exposure } \\
(\text { days })\end{array}$ & Failure \\
\hline Alloy C-276 & $\mathbf{3 7}$ & $\mathbf{3 1 6}$ & $\mathbf{5 3 5}$ & 100 & $>100$ & No \\
& $\mathbf{4 8}$ & $\mathbf{3 1 6}$ & $\mathbf{5 3 5}$ & 100 & $>100$ & No \\
& $\mathbf{5 9}$ & $\mathbf{3 1 6}$ & $\mathbf{2 6 6}$ & $\mathbf{1 0 0}$ & $>100$ & No \\
& $\mathbf{5 9}$ & $\mathbf{4 2 7 - 5 3 8}$ & $\mathbf{5 0}$ & 100 & $>100$ & No \\
Alloy 625 & $\mathbf{5 9}$ & $\mathbf{3 1 6}$ & $\mathbf{5 3 5}$ & 100 & $>100$ & No \\
\hline
\end{tabular}

a Tests were conducted in an aqueous solution containing $5 \% \mathrm{NaCl}$ and $0.5 \%$ acetic acid, saturated with $100 \% \mathrm{H} 2 \mathrm{~S}$ gas $(\mathrm{NACE}$ solution). Tests were conducted at atmospheric pressure with $\mathrm{H}_{2} \mathrm{~S}$ continuously bubbled through the solution for the duration of the test.

Because of the interest in the use of Ni-Cr-Mo alloys in sour-gas wells, most of the literature is concemed with the embrittlement of work-hardened alloys. The emphasis has primarily been on the mechanism of failure and the microstructural changes that occur upon cold working and aging. A few studies have dealt with annealed alloys and these will be presented.

The Ni-Cr-Mo alloys have known susceptibility to $\mathrm{HE}$, especially when hydrcgen is introduced into the material by corrosion. Several factors may affect the susceptibility of these alloys to $\mathrm{HE}$, including composition, cold working, aging, impurities, temperature, stressing direction, and environment. These topics are covered in the following sections for Alloys $\mathrm{C}-4$, $\mathrm{C}-276$, and 625 . Unfortunately, no data were found on Alloy C-22.

\subsection{Immunity of Uncoupled Specimens to $\mathrm{HE}$}

Work-hardened Ni-Cr-Mo alloys are not susceptible to HE unless they are galvanically coupled to a less noble material (or cathodically charged with hydrogen). This immunity has been observed for Alloys C-276 and 625 under a variety of conditions (Kane et al. 1977) (Table 52). At an applied stress of $100 \%$ of transverse yield stress, these alloys are resistant to cracking in the $\mathrm{NACE}$ solution $(5 \% \mathrm{NaCl}$ and $0.5 \%$ acetic acid saturated with $100 \% \mathrm{H}_{2} \mathrm{~S}$ gas) at room temperature. Kane et al. did not observe failures for exposures greater than 100 days. Specimens included ones that were coldrolled 37 to $59 \%$ and aged for long times ( 50 to $535 \mathrm{~h}$ ) at elevated temperatures $\left(316\right.$ to $\left.538^{\circ} \mathrm{C}\right)$.

In contrast, when these alloys (except for annealed specimens) are galvanically coupled, they are highly susceptible to HE. Cold working, aging at e'evated temperatures, stress level, stressing direction, and solution composition and temperature all affect the alloys' susceptibility to HE when coupled. These topics are covered in detail in the following sections.

\subsection{Effect of Alloy Composition}

Table 53 shows the effect of composition on the susceptibility of nickel-based alloys to HE at room temperature (Kane et al. 1977). For unaged specimens of Alloys C-276, C-4, and 625, which were cold-rolled $59 \%$, steel-coupled in the NACE solution, and stressed to $100 \%$ yield stress, it was found that Alloy C-276 had much greater resistance to failure than Alloys $\mathrm{C}-4$ and 625. Alloy C-276 did not fail in 100 days, while Alloys 625 and $C-4$ failed in much shorter times: 11 days and less than 3 days, respectively.

Bulk impurities did not affect the susceptibility of unaged Alloy C-276 (Berkowitz and Kane 1980). Unaged specimens with 0.023 and $0.002 \mathrm{wt} \%$ phosphorus impurity did not fail in times up to 36 days. When the specimens were aged, however, those with more phosphorus failed sooner, as discussed in Sec. 5.5.

\subsection{Effect of Stressing Direction}

Specimens stressed longitudinally to the coldrolling direction have a much greater resistance to $\mathrm{HE}$ than specimens stressed transversely. Alloy C-276 (59\% cold-rolled) did not fail when it was stressed in the longitudinal direction under a variety of conditions in the NACE solution at room temperature. These results are shown in Table 54 (Kane et al. 1977). No embrittlement was found (1) in the aged and unaged condition, (2) with and without a circumferential notch, 
Table 53. Results of tests on C-ring specimens of Alloys C-276, C-4, and 625. The alloys were tested in roomtemperature NACE solution with steel couples (Kane et al. 1977). The composition of the NACE solution is given in Table 52.

\begin{tabular}{|c|c|c|c|c|c|c|}
\hline Material & $\begin{array}{l}\text { Percent } \\
\text { cold work }\end{array}$ & $\begin{array}{l}\text { Aging temp } \\
\left({ }^{\circ} \mathrm{C}\right)\end{array}$ & $\begin{array}{l}\text { Aging time } \\
\text { (h) }\end{array}$ & $\begin{array}{l}\text { Applied stress } \\
\text { (\% transverse } \\
\text { yield stress) }\end{array}$ & Failure & $\begin{array}{c}\text { Exposure } \\
\text { (days) }\end{array}$ \\
\hline Alloy C-276 & $\begin{array}{l}37 \\
48 \\
59 \\
37 \\
48 \\
59\end{array}$ & $\begin{array}{l}500 \\
500 \\
500 \\
\text { Unaged } \\
\text { Unaged } \\
\text { Unaged }\end{array}$ & $\begin{array}{l}1 \\
1 \\
1\end{array}$ & $\begin{array}{l}100 \text { and } 90 \\
100 \text { and } 90 \\
100 \text { and } 90 \\
100 \\
100 \\
100\end{array}$ & $\begin{array}{l}\text { Yes } \\
\text { Yes } \\
\text { Yes } \\
\text { No } \\
\text { No } \\
\text { No }\end{array}$ & $\begin{array}{l}a \\
a \\
>100 \\
>100 \\
>100\end{array}$ \\
\hline Alloy C 4 & $\begin{array}{l}48 \\
48 \\
59 \\
59 \\
59 \\
59 \\
59 \\
59\end{array}$ & $\begin{array}{l}\text { Unaged } \\
\text { Unaged } \\
538 \\
538 \\
\text { Unaged } \\
\text { Unaged } \\
\text { Unaged } \\
\text { Unaged }\end{array}$ & $\begin{array}{r}1 \\
10\end{array}$ & $\begin{array}{l}100 \\
90 \\
100 \\
100 \\
100 \\
90 \\
70 \\
50\end{array}$ & $\begin{array}{l}\text { Yes } \\
\text { No } \\
\text { Yes } \\
\text { Yes } \\
\text { Yes } \\
\text { Yes } \\
\text { Yes } \\
\text { No }\end{array}$ & $\begin{array}{l}<3 \\
>100 \\
<3 \\
<3 \\
<3 \\
<3 \\
10 \\
>100\end{array}$ \\
\hline Alloy 625 & $\begin{array}{l}\mathbf{5 9} \\
\mathbf{5 9} \\
\mathbf{5 9} \\
\mathbf{5 9} \\
\mathbf{5 9} \\
\mathbf{5 9} \\
\mathbf{5 9} \\
\mathbf{5 9} \\
\mathbf{5 9} \\
\mathbf{5 9} \\
\mathbf{5 9}\end{array}$ & $\begin{array}{l}538 \\
538 \\
371 \\
371 \\
371 \\
371 \\
204 \\
204 \\
204 \\
\text { Unaged } \\
\text { Unaged }\end{array}$ & $\begin{array}{r}1 \\
10 \\
20 \\
287 \\
287 \\
287 \\
250 \\
250 \\
250\end{array}$ & $\begin{array}{l}100 \\
100 \\
100 \\
100 \\
90 \\
70 \\
100 \\
90 \\
70 \\
100 \\
90\end{array}$ & $\begin{array}{l}\text { Yes } \\
\text { Yes } \\
\text { Yes } \\
\text { Yes } \\
\text { Yes } \\
\text { Yes } \\
\text { Yes } \\
\text { Yes } \\
\text { No } \\
\text { Yes } \\
\text { No }\end{array}$ & $\begin{array}{l}<3 \\
<3 \\
<3 \\
<3 \\
<3 \\
35 \\
<3 \\
<3 \\
>100 \\
11 \\
>100\end{array}$ \\
\hline
\end{tabular}

Exposure time was not given.

Table 54. Results of tensile tests conducted in NACE solution at room temperature (Kane et al. 1977). Tensile specimens of 56\% cold-rolled Alloy C-276 were stressed longitudinally to the rolling direction. Specimens were aged for $100 \mathrm{~h}$ at $500^{\circ} \mathrm{C}$. The composition of the NACE solution is given in Table 52.

\begin{tabular}{|c|c|c|c|c|c|}
\hline $\begin{array}{l}\text { Applied stress } \\
\text { (\% yield stress) }\end{array}$ & Aged & Steel-coupled & Notched & $\begin{array}{l}\text { Exposure } \\
\text { (h) }\end{array}$ & Failure \\
\hline 98 & No & No & No & 720 & No \\
\hline 98 & No & No & Yes & 720 & No \\
\hline 110 & No & Yes & No & 700 & No \\
\hline 104 & Yes & No & Yes & 900 & No \\
\hline 104 & Yes & No & No & 1000 & No \\
\hline 98 & Yes & Yes & No & 1230 & No \\
\hline 105 & Yes & Yes & No & 700 & No \\
\hline 110 & Yes & Yes & No & $>2436$ & No \\
\hline
\end{tabular}


Table 55. Effects of cold work and stressing direction on the TTF of cathodically charged Alloy C-276 (Asphahani 1977). Tests were performed in a solution of 5 vol\% $\mathrm{H}_{2} \mathrm{SO}_{4}+\mathrm{As}_{2} \mathrm{O}_{3}$ at $25^{\circ} \mathrm{C}$, with $i_{\mathrm{c}}$ equal to $40 \mathrm{~mA} / \mathrm{cm}^{2}$. Specimens were plastically strained (7\%).

\begin{tabular}{cccc}
\hline \multirow{2}{*}{$\begin{array}{c}\text { Percent } \\
\text { cold work }\end{array}$} & Hardness & \multicolumn{2}{c}{ TTF (h) } \\
\cline { 3 - 4 } & Longitudinal & Transverse \\
\hline 0 & Rb 90 & - & $>200$ \\
10 & Rc 24 & $84-102$ & $86-96$ \\
20 & Rc 29 & - & $88-92$ \\
30 & Rc 35 & $79-112$ & $87-99$ \\
40 & Rc 38 & - & $88-94$ \\
50 & Rc 41 & $78-94$ & $42-50$ \\
60 & Rc 43 & $79-81$ & $11-13$ \\
\hline
\end{tabular}

(3) with and without a steel couple, and (4) when loaded to stresses above $100 \%$ of its yield strength in the longitudinal direction. In contrast, specimens of the $\mathrm{Ni}-\mathrm{Cr}$-Mo alloys stressed in the transverse direction fail under a variety of conditions, which are discussed in the following sections.

The high resistance of the Ni-Cr-Mo alloys to cracking in NACE solutions when stressed longitudinally to the rolling direction was also shown by Watkins and Greer (1976). The specimens were stressed to $98 \%$ of their yield stress at room temperature. No failures were reported for Alloys C-276 and 625. In addition, titanium was tested and did not fail. However, the susceptibility of longitudinally stressed specimens of Alloy C-276 to HE has been observed under cathodic hydrogen charging (Asphahani 1977). These results are shown in Table 55. Specimens stressed in the transverse direction had shorter failure times than those stressed in the longitudinal direction. This finding is in qualitative agreement with the other studies that show that transversely stressed specimens are significantly more susceptible to $\mathrm{HE}$ than longitudinally stressed specimens. In addition, increased cold rolling decreased the time to failure (TTF) to HE for both types of stressing (see Sec. 5.4).

\subsection{Effect of Cold Work}

Increased cold working of Alloy C-276 increases its susceptibility to HE. This effect is illustrated by cathodic hydrogen charging experiments performed in a solution of 5 vol\% $\mathrm{H}_{2} \mathrm{SO}_{4}+\mathrm{As}_{2} \mathrm{O}_{3}$ at $25^{\circ} \mathrm{C}$ (Table 55) (Asphahani 1977). [Note that the concentration of $\mathrm{As}_{2} \mathrm{O}_{3}$ was not specified in Asphahani (1977).] The specimens were stressed longitudinally and transversely to the rolling direction. Annealed specimens did not fail in times greater than $200 \mathrm{~h}$. In contrast, any amount of cold working caused failure of the specimens, with stressing in the transverse direction being more deleterious. For transverse stressing, the 10 to $40 \%$ coldworked specimens all failed in 86 to $99 \mathrm{~h}$, the $50 \%$ coldworked specimens in about half the time ( $42-50 \mathrm{~h})$, and the $60 \%$ cold-worked specimens in much shorter times (11-13 h). Fáilure times for longitudinal stressing did not show quite as strong a dependence on cold working as did failure times for transverse stressing.

Cold working of the $\mathrm{Ni}-\mathrm{Cr}$-Mo alloys generally increases their susceptibility to HE in the NACE solution. This change in susceptibility is illustrated in Table 53 for transverse stressing of specimens at room temperature in the NACE solution. For unaged Alloy $\mathrm{C}-4,48 \%$ and $59 \%$ cold-rolled specimens failed at an applied stress of $\geq 100 \%$ yield stress and $\geq 70 \%$ yield stress, respectively. However, Alloy C-276 is more resistant to HE. Unaged specimens with 37 to $59 \%$ cold rolled did not fail in 100 days when stressed to $100 \%$ transverse yield stress.

The reason for the enhanced susceptibility of coldworked material to $\mathrm{HE}$ is thought to be that cold working changes the defect density of the material in comparison with an annealed specimen (Berkowitz and Kane 1980). Berkowitz and Kane state:

Cold working produces many vacancies as well as a very high dislocation density. Upon heating, lattice diffusion is enhanced by the excess vacancy concentration (Russel and Vela 1963) and, more importantly, pipe diffusion will occur along the many dislocations (Shewmon 1963). Also, it has been demonstrated in surface segregation experiments that prior cold work increases the kinetics of substitutional impurity segregation.

\subsection{Effect of Aging}

Aging of Ni-Cr-Mo alloys at elevated temperatures increases their susceptibility to HE when the specimens are cold-worked and steel-coupled. The effect of aging of Alloys $625, \mathrm{C}-276$, and $\mathrm{C}-4$ in the temperature range of 148 to $500^{\circ} \mathrm{C}$ is shown in Table 53 and Figs. 22 and 23 (Kane et al. 1977). The specimens had various amounts of cold work and were tested in the NACE solution at room temperature. To induce $H E$ failure at an applied stress level of $100 \%$ of the transverse $0.2 \%$ offset yield stress, longer aging times were required to 

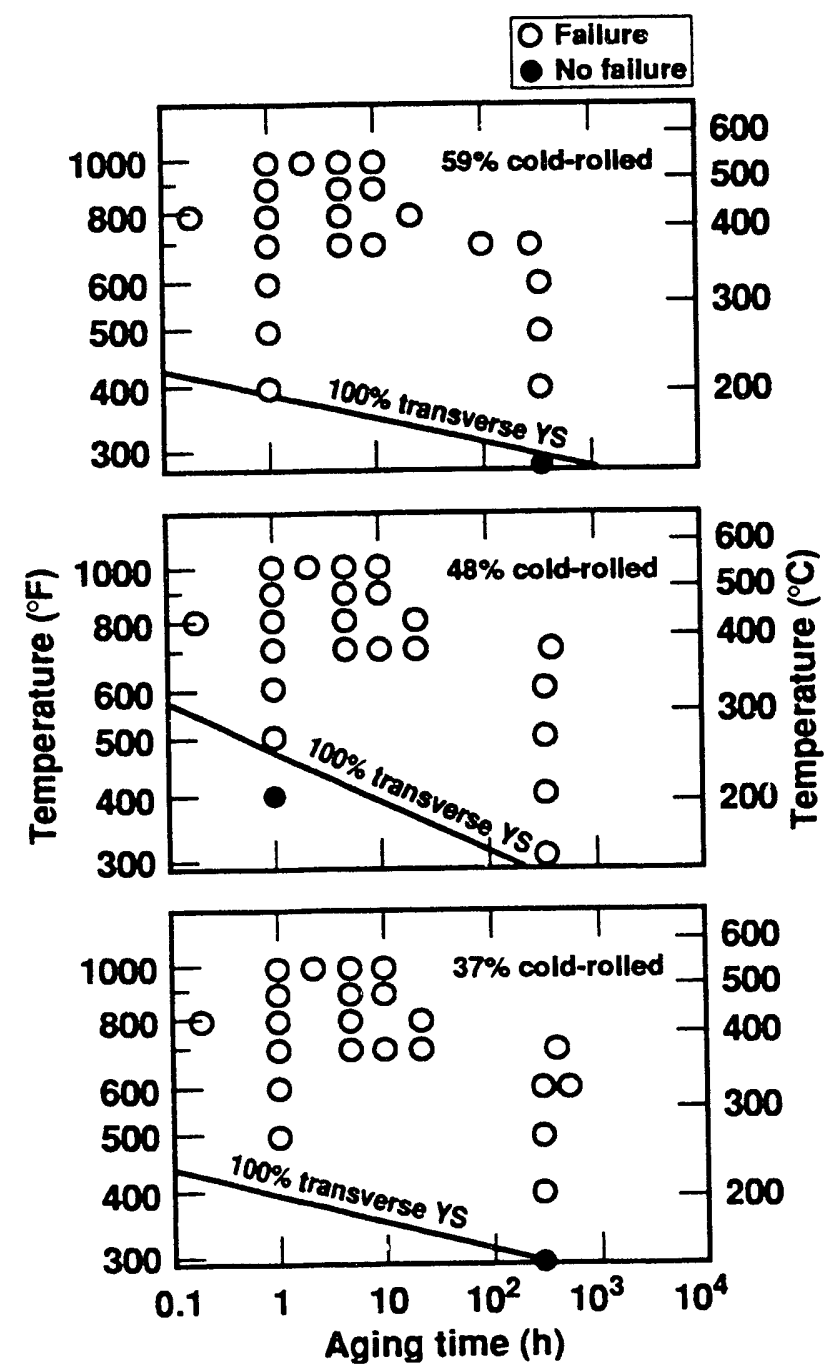

Figure 22. Results of C-ring tests on steel-coupled Alloy C-276 at room temperature after aging at temperatures between $148^{\circ}$ and $593^{\circ} \mathrm{C}$ (Kane et al. 1977). Tests were conducted in the NACE solution at applied stress levels of $100 \%$ of the transverse $0.2 \%$ offset yield stress. Lines divide regions of failure and no failure.

induce failure for lower aging temperatures. For stressing at $90 \%$ of yield stress, longer aging times were also required to induce $\mathrm{HE}$ at the lower aging temperatures, but the resistance to $\mathrm{HE}$ was observed for higher aging temperatures $\left(300-200^{\circ} \mathrm{C}\right)$.

Aging of Alloy C-276 increases its susceptibility to HE during cathodic charging (Sridhar et al. 1980b). Crack-growth rates at a given stress intensity factor increased significantly as specimens of Alloy C-276 were aged at $500^{\circ} \mathrm{C}$. TTF decreased with increasing aging time (Fig. 24). Specimens were aged from 0.1 to $1500 \mathrm{~h}$
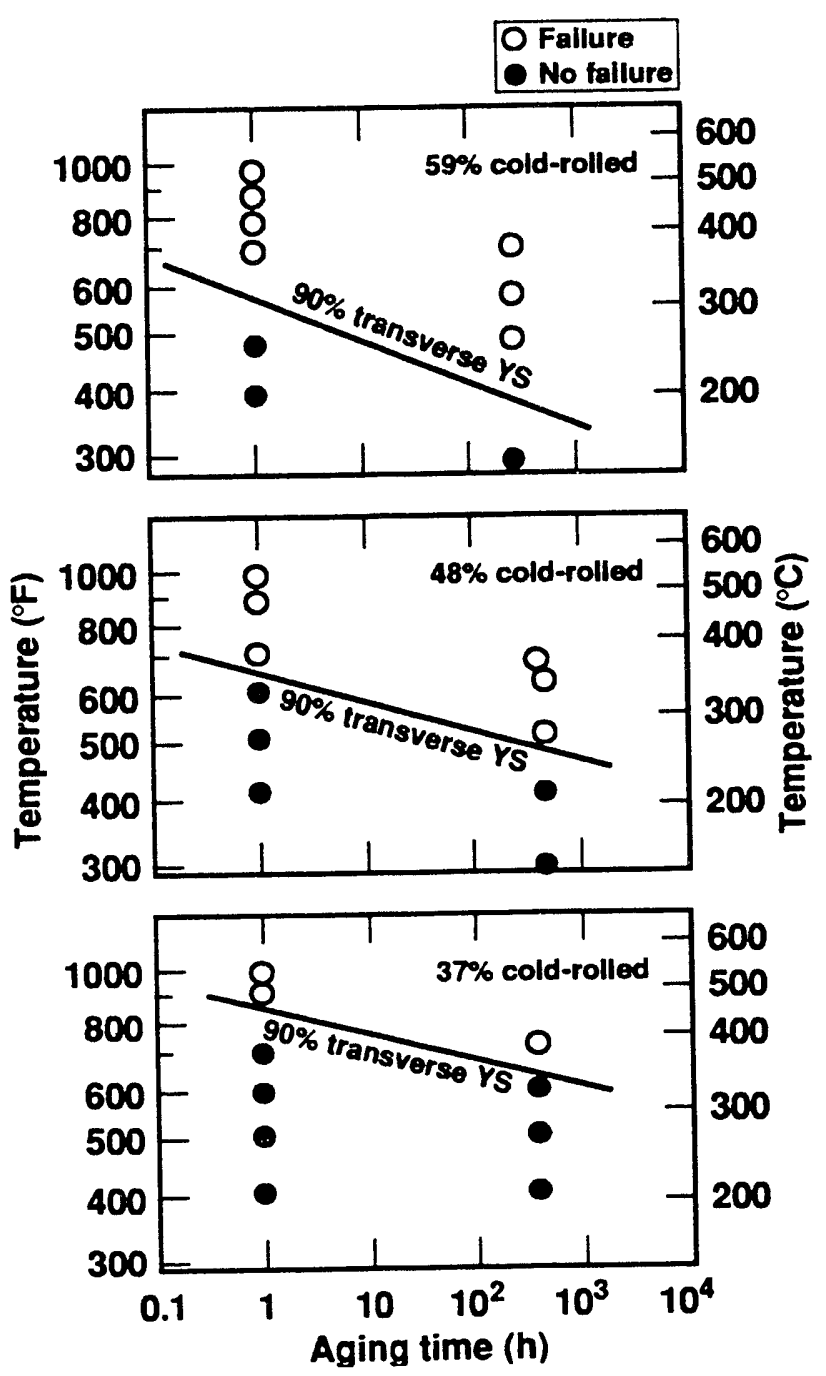

Figure 23. Similar to Fig. 22, but showing results of tests conducted at applied stress levels of $90 \%$ of the transverse $0.2 \%$ offset yield stress (Kane et al. 1977).

at $500^{\circ} \mathrm{C}$. A three-stage crack-growth phenomenon is also seen in Alloy C-276 during cathodic charging.

Aging may induce segregation of minority species to grain boundaries and therefore affect resistance to HE. Studies of the effect of phosphorus content on the susceptibility of Alloy C-276 to HE have indicated that some of the susceptibility may result from phosphorus segregation to grain boundaries during aging (Berkowitz and Kane 1980). It was experimentally shown that aging causes the segregation of phosphorus to the grain boundaries. Sheet specimens with 0.023 and $0.002 \mathrm{wt} \%$ phosphorus were tested in the NACE solution for cracking susceptibility (Table 56 ). The alloy with the lower phosphorus content generally had greater resistance to cracking. Tests were conducted 
Figure 24. Effect of $500^{\circ} \mathrm{C}$ aging time on stage $\mathrm{I}$ crack velocity, mean TTF, and hardness of cold-worked Alloy C276 (Sridhar et al. 1980b).

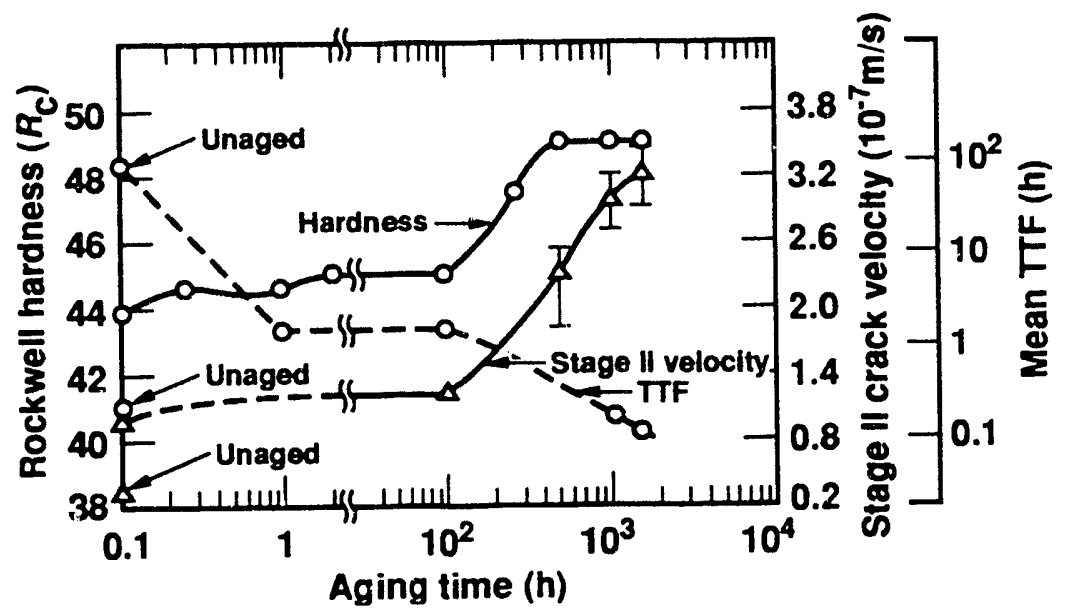

Table 56. Effect of aging severity and bulk impurity level on the cracking susceptibility of Alloy C-276 sheet (Berkowitz and Kane 1980). The commercialpurity specimen had $0.023 \mathrm{wt} \%$ phosphorus, and the high-purity specimen had 0.002 wt \% phosphorus.

\begin{tabular}{|c|c|c|c|}
\hline \multirow{2}{*}{$\begin{array}{c}\text { Aging } \\
\text { temp } \\
\left({ }^{\circ} \mathrm{C}\right)\end{array}$} & \multirow{2}{*}{$\begin{array}{l}\text { Aging } \\
\text { time } \\
\text { (days) }\end{array}$} & \multicolumn{2}{|c|}{ TTF (days) } \\
\hline & & $\begin{array}{c}\text { Commercial } \\
\text { purity }\end{array}$ & $\begin{array}{c}\text { High } \\
\text { purity }\end{array}$ \\
\hline \multicolumn{4}{|c|}{$50 \%$ cold-reduced sheet } \\
\hline Unaged & - & 36 & 36 \\
\hline 204 & 200 & 13 & 36 \\
\hline 371 & 20 & $<3$ & 9 \\
\hline 482 & 0.16 & $<3$ & 36 \\
\hline 482 & 100 & $<3$ & $<3$ \\
\hline \multicolumn{4}{|c|}{$60 \%$ cold-reduced sheet } \\
\hline Unaged & - & 36 & 36 \\
\hline 204 & 200 & $<3$ & 36 \\
\hline 371 & 20 & $<3$ & 36 \\
\hline 482 & 0.16 & $<3$ & 36 \\
\hline 482 & 100 & $<3$ & $<3$ \\
\hline
\end{tabular}

using specimens that were 50 and $60 \%$ cold-worked, for various aging times and temperatures. Similar experiments were also performed on C-ring specimens, but these results did not demonstate that specimens of low phosphorus content had a greater resistance to $\mathrm{HE}$.

Aging of Alloy C-276 causes hardening that is due to microstructural changes (Fig. 24) (Sridhar et al. $1980 \mathrm{~b})$. Short-time aging $(<0.1 \mathrm{~h})$ at $500^{\circ} \mathrm{C}$ causes short-range ordering (SRC) that results in a steep increase in hardness. Short-time aging at $500^{\circ} \mathrm{C}$ also causes impurity segregation (e.g., phosphorus) to grain boundaries, but this phenomenon has no effect on the hardness. Aging between 0.1 and $100 \mathrm{~h}$ increases the hardness only slightly. After $100 \mathrm{~h}$ of aging, there is another increase in hardness that is due to long-range ordering effects. The ordered phase may possibly be $\mathrm{Ni}_{2}(\mathrm{Cr}, \mathrm{Mo})$, which is similar to $\mathrm{Ni}_{2} \mathrm{Cr}$ that has been seen in Ni-Cr alloys upon aging (Kane et al. 1977).

HE of Alloy C-276 by aging at elevated temperatures $\left(500^{\circ} \mathrm{C}\right)$ is thought to be due to both impurity segregation and microstructural ordering. Aging for short times $(<0.1 \mathrm{~h})$ causes impurity segregation to grain boundaries and SRO. Aging for long times $(>100 \mathrm{~h})$ causes long range ordering.

\subsection{Effect of Hydrogen Charging Current and Electrolytes on $\mathbf{H E}$}

The susceptibility of the cold-worked Ni-Cr-Mo alloys to HE is dependent on their coupling to a less noble material in a suitable environment. Furthermore, the TTF is dependent on the particular environment and the charging current density. Kane (1978) has quantitatively studied the effect of charging current density on the TTF of several high-nickel alloys, among them Alloys 625 and C-276. The logarithm of the TTF was found to decrease linearly with the logarithm of charging current for these materials (Fig. 25). However, the absolute value of the TTF did vary with electrolyte and aging (see Sec. 5.5). The times to failure for specimens in NACE solutions were 2.5 to 3 times greater than for corresponding specimens tested in an aqueous $5 \%$ $\mathrm{H}_{2} \mathrm{SO}_{4}$ solution containing $100 \mathrm{mg} / \mathrm{l}$ sodium arsenite. The slopes of the log TTF vs log current density curves were similar for a given alloy regardless of specimen 


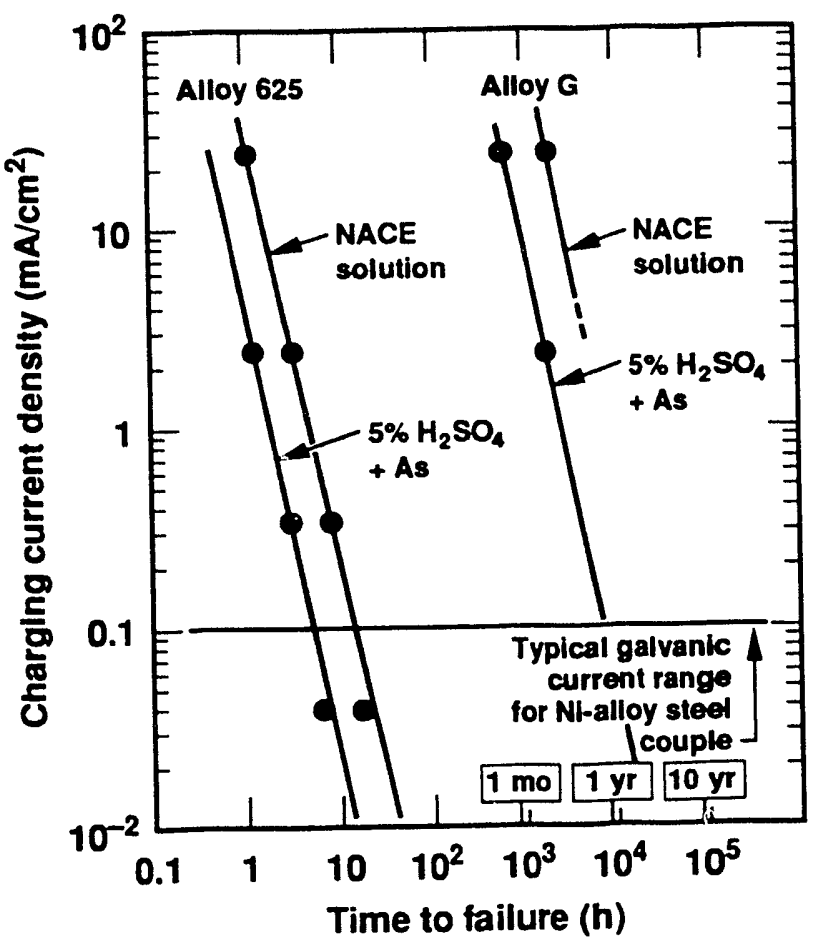

Figure 25. Effect of test environment and charging current density on the failure time of stressed C-ring specimens of Alloy 625 (59\% cold-worked + $500^{\circ} \mathrm{C} / 50 \mathrm{~h}$ ) and Alloy G (59\% cold-worked + $260^{\circ} \mathrm{C} / 250 \mathrm{~h}$ ) (Kane 1978).

aging or solution composition. Kane suggested that diagrams of the type of Figs. 25 and 26 allow TTF extrapolation from short-time charging data for a particular solution.

Kane states that the complex interaction between hydrogen entry and the HE of metals during cathodic charging does not presently permit a complete understanding of the relationship between charging current and TTF. He states that two factors that could affect the $\log$ current vs log TTF curves are (1) the rate of hydrogen recombination on the metal surface, and (2) the hydrogen mobility in the metal.

\subsection{Effect of Temperature}

Elevated-temperature testing reduced the susceptibility of the Ni-Cr-Mo alloy to HE (Tables 57 and 53) (Kane et al. 1977). Specimens of Alloys C-276 and 625 stressed at $100 \%$ yield stress were tested for cracking in the NACE solution as a function of test temperature and aging. Unaged Alloy C-276 specimens did not fail at any test temperature (room temperature, $107^{\circ} \mathrm{C}$, and

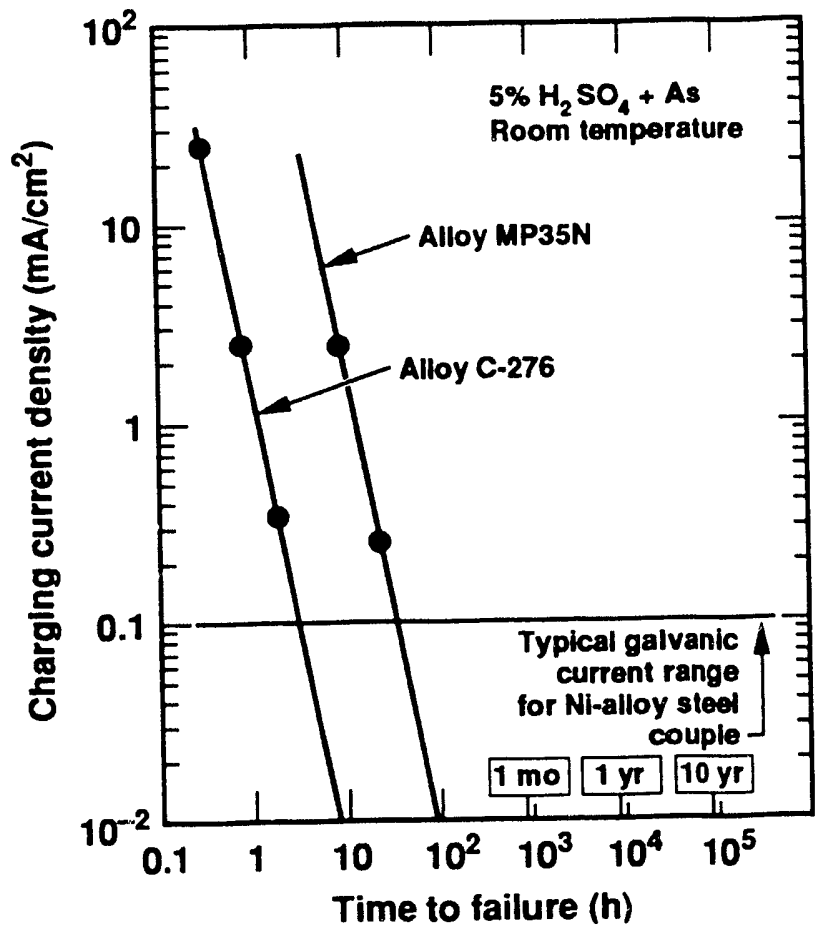

Figure 26. Effect of charging current density on the failure time of stressed $\mathrm{C}$-ring specimens of Alloys C-276 (59\% cold-rolled $+500^{\circ} \mathrm{C} / 100 \mathrm{~h}$ ) and MP35N $\left(59 \%\right.$ cold-rolled $\left.+593^{\circ} \mathrm{C} / 4 \mathrm{~h}\right)$ in $5 \% \mathrm{H}_{2} \mathrm{SO}_{4}$ solution containing sodium arsenite (Kane 1978).

$149^{\circ} \mathrm{C}$ ). After aging at $500^{\circ} \mathrm{C}$ for $100 \mathrm{~h}$, specimens of Alloy C-276 were susceptible to cracking at room temperature, $65^{\circ} \mathrm{C}$, and $107^{\circ} \mathrm{C}$, but not $149^{\circ} \mathrm{C}$.

Alloy 625 showed a similar decrease in HE susceptibility with increasing test temperature. At $100 \%$ transverse yield stress, unaged specimens failed at room temperature but not $149^{\circ} \mathrm{C}$, and aged specimens $\left(500^{\circ} \mathrm{C}\right.$, 1 to $100 \mathrm{~h}$ ) failed at room temperature but not $107^{\circ} \mathrm{C}$ and $149^{\circ} \mathrm{C}$. Both Alloy C-276 and Alloy 625 therefore have increased resistance to $\mathrm{HE}$ at elevated temperatures. However, aged Alloy 625 appears to have better resistance at lower temperatures than aged Alloy C-276.

The decrease of the susceptibility of alloys to $\mathrm{HE}$ can be explained in terms of the effect of temperature on hydrogen population at defect sites. Hydrogen accumulation at defect sites, e.g., dislocations, is thought to contribute significantly to the embrittlement process. Defect sites are lower-energy sites for hydrogen, and the hydrogen population of these sites is favored at low temperatures. At higher temperatures, the hydrogen is distributed more uniformly throughout the lattice, and the material's susceptibility to embrittlement is decreased. 
Table 57. C-ring specimens tested in elevated-temperature NACE solution with steel couples (Kane et al. 1977).

\begin{tabular}{|c|c|c|c|c|c|c|}
\hline Material & $\begin{array}{l}\text { Percent } \\
\text { cold work }\end{array}$ & $\begin{array}{l}\text { Aging temp } \\
\left({ }^{\circ} \mathrm{C}\right)\end{array}$ & $\begin{array}{l}\text { Aging time } \\
\text { (h) }\end{array}$ & $\begin{array}{c}\text { Applied stress } \\
\text { (\% transverse } \\
\text { yield stress) }\end{array}$ & $\begin{array}{c}\text { Exposure } \\
\text { (days) }\end{array}$ & Failure \\
\hline \multicolumn{7}{|l|}{$149^{\circ} \mathrm{C}$} \\
\hline Alloy C-276 & $\begin{array}{l}59 \\
59\end{array}$ & $\begin{array}{l}500 \\
\text { Unaged }\end{array}$ & 100 & $\begin{array}{r}100 \\
90\end{array}$ & $\begin{array}{l}30 \\
\mathbf{3 0}\end{array}$ & $\begin{array}{l}\text { No } \\
\text { No }\end{array}$ \\
\hline Alloy 625 & $\begin{array}{l}59 \\
59\end{array}$ & $\begin{array}{l}500 \\
\text { Unaged }\end{array}$ & - & $\begin{array}{r}100 \\
90 \\
100 \\
90\end{array}$ & $\begin{array}{l}30 \\
30 \\
30 \\
30\end{array}$ & $\begin{array}{l}\text { No } \\
\text { No } \\
\text { No } \\
\text { No }\end{array}$ \\
\hline \multicolumn{7}{|l|}{$107^{\circ} \mathrm{C}$} \\
\hline Alloy C-276 & $\begin{array}{l}59 \\
59\end{array}$ & $\begin{array}{l}500 \\
\text { Unaged }\end{array}$ & - & $\begin{array}{r}100 \\
90 \\
100 \\
90\end{array}$ & $\begin{array}{l}14 \\
14 \\
14 \\
14\end{array}$ & $\begin{array}{l}\text { Yes } \\
\text { Yes } \\
\text { No } \\
\text { No }\end{array}$ \\
\hline Alloy 625 & 59 & 500 & 100 & 100 & 28 & No \\
\hline \multicolumn{7}{|l|}{$65^{\circ} \mathrm{C}$} \\
\hline Alloy C-276 & 59 & 500 & 100 & $\begin{array}{r}100 \\
90 \\
70\end{array}$ & $\begin{array}{l}<14 \\
<14 \\
<14\end{array}$ & $\begin{array}{l}\text { Yes } \\
\text { Yes } \\
\text { Yes }\end{array}$ \\
\hline
\end{tabular}

ane specimen failed and the other did not.

Tests were conducted in an aqueous solution containing $5 \% \mathrm{NaCl}$ and $0.5 \%$ acetic acid, saturated with $100 \% \mathrm{H} 2 \mathrm{~S}$ gas (NACE solution). The $65^{\circ} \mathrm{C}$ tests rzere conducted at atmospheric pressure with $\mathrm{H}_{2} \mathrm{~S}$ continuously bubbled through the solution for the duration of the test. The 107 and $149^{\circ} \mathrm{C}$ tests were conducted at pressures above the vapor pressure of the solution in an autoclave. The autoclave was purged with nitrogen before and after heating to the testing temperature. It was then pressurized to 70 to 100 psi $(0.52$ to $0.69 \mathrm{MPa})$ with $\mathrm{H}_{2} \mathrm{~S}$ gas.

\subsection{Effect of Solution Composition}

A majority of the studies on the $\mathrm{HE}$ of $\mathrm{Ni}-\mathrm{Cr}-\mathrm{Mo}$ alloys have been performed in atmospheres containing $\mathrm{H}_{2} \mathrm{~S}$ because of the oil industry's interest in using these alloys in sour-gas wells. Indeed, many of the studies cited in this report used atmospheres containing $\mathrm{H}_{2} \mathrm{~S}$. Cold-worked, aged, and steel-coupled Ni-Cr-Mo alloys are highly susceptible to $\mathrm{HE}$ in these atmospheres.

The Ni-Cr-Mo alloys have better resistance to $\mathrm{HE}$ when an oxygen purge is substituted for an $\mathrm{H}_{2} \mathrm{~S}$ purge in aqueous solutions of $5 \% \mathrm{NaCl}$ and $0.5 \%$ acetic acid (Table 58) (Kane et al. 1977). For exposure times up to 25 days, no failures were reported for uncoupled Alloys C-276 and 625 stressed to $100 \%$ of their transverse yield stress. However, Alloy 625 failed when it was coupled to steel. More important, the TTF was approx- imately 3 to 5 times greater than those determined for comparably aged specimens tested in NACE solution.

Kane and coworkers suggested that the decrease in the TTF in the NACE solution was due to the effect of $\mathrm{H}_{2} \mathrm{~S}$ on the rate of hydrogen recombination on the metallic surface. It was suggested that $\mathrm{H}_{2} \mathrm{~S}$ promotes the absorption of atomic hydrogen and therefore increases the susceptibility to embrittlement in aqueous environments.

\subsection{Effect of Stress Level}

Stress levels near the yield stress of the alloys appear to be necessary for HE to occur (Table 59). However, HE has been reported for stress levels near $50 \%$ of the yield stress. Unaged Alloy C-276 $(37,48$, 
Table 58. C-ring specimens tested in an aqueous solution saturated with oxygen at room temperature (Kane et al. 1977).

\begin{tabular}{|c|c|c|c|c|c|c|}
\hline Material & $\begin{array}{l}\text { Percent } \\
\text { cold-rolled }\end{array}$ & $\begin{array}{l}\text { Aging temp } \\
\left({ }^{\circ} \mathrm{C}\right)\end{array}$ & $\begin{array}{c}\text { Aging time } \\
\text { (h) }\end{array}$ & $\begin{array}{c}\text { Applied stress } \\
\text { (\% transverse } \\
\text { yield stress) }\end{array}$ & $\begin{array}{c}\text { Exposure } \\
\text { (days) }\end{array}$ & Failure \\
\hline \multicolumn{7}{|c|}{ C-rings without steel couple } \\
\hline Alloy C-276 & 48 & $\mathbf{5 0 0}$ & 100 & 100 & 25 & No \\
\hline Alloy 6.25 & 59 & 500 & 100 & 100 & 25 & No \\
\hline \multicolumn{7}{|c|}{ C-rings with steel couple } \\
\hline Alloy C-276 & 48 & 500 & 100 & 100 & 25 & No \\
\hline Alloy 625 & 59 & 500 & 100 & 100 & 9 & Yes \\
\hline
\end{tabular}

Tests were conducted in an aqueous solution containing $5 \% \mathrm{NaCl}$ and $0.5 \%$ acetic acid.

Table 59. Effect of applied stress level on cracking in steel-coupled C-ring specimens in the NACE solution (Kane et al. 1977). Alloys were 59\% cold-rolled.

\begin{tabular}{lccc}
\hline Alloy & $\begin{array}{c}\text { Applied stress } \\
\text { (\% of } \\
\text { yield stress) }\end{array}$ & $\begin{array}{c}\text { Exposure } \\
\text { (days) }\end{array}$ & Failure \\
\hline C-276 & 100 & $>100$ & No \\
625 & 100 & 11 & Yes \\
& 90 & $>100$ & No \\
C-4 & 100 & $<3$ & Yes \\
& 90 & $<3$ & Yes \\
& 70 & 10 & Yes \\
& 50 & $>100$ & No \\
\hline
\end{tabular}

and $59 \%$ cold-rolled) was resistant to embrittlement at an applied stress of $100 \%$ of the transverse yield stress. Unaged Alloy 625 (59\% cold-rolled) and Alloy C-4 ( $48 \%$ cold-rolled) were resistant at $90 \%$ of their transverse yield stresses but not at $100 \%$. Unaged Alloy C -4 (59\% cold-rolled) failed at stresses above $50 \%$ of its transverse yield stress.

\subsection{Hydrogen Diffusivity}

Hydrozen diffusivity has been measured in Alloy C-276 as a function of thermomechanical treatment by electrolytic permeability measurement (Fiore and Kargol 1981, Mezzanotte et al. 1980). In the temperature range of 17 to $90^{\circ} \mathrm{C}$, hydrogen diffusivity was measured in annealed, annealed plus aged, cold-worked,

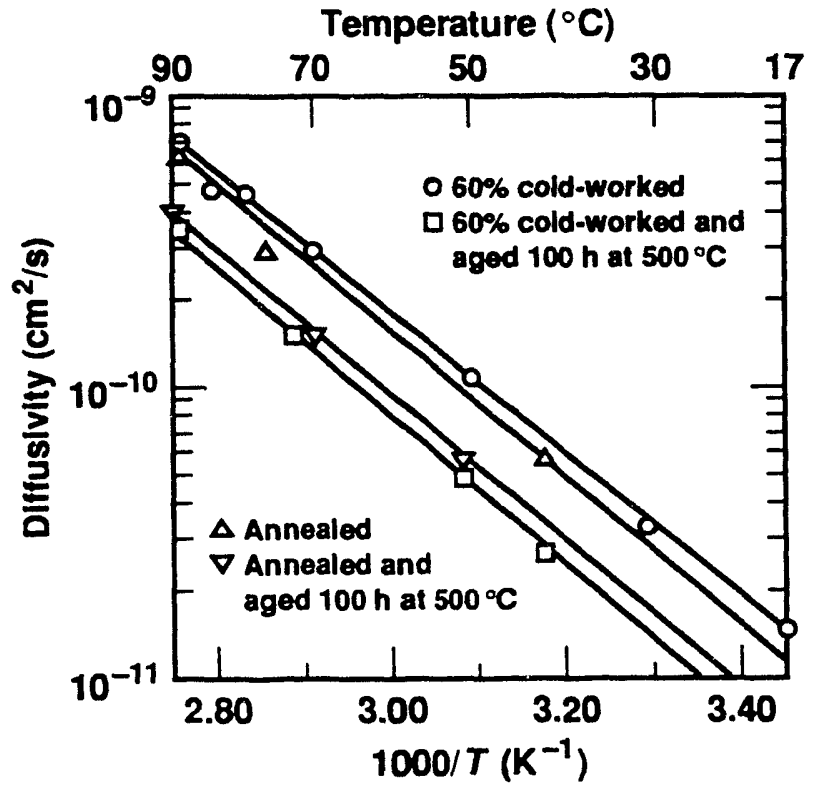

Figure 27. Hydrogen diffusivity in Alloy C-276 (Fiore and Kargol 1981).

and cold-worked plus aged foils (Fig. 27) (Fiore and Kargol 1980). Diffusivities in the annealed and coldworked specimens were similar, varying from 1-2 $\times$ $10^{-11} \mathrm{~cm}^{2} / \mathrm{s}$ at $17^{\circ} \mathrm{C}$ to about $7 \times 10^{-10} \mathrm{~cm}^{2} / \mathrm{s}$ at $90^{\circ} \mathrm{C}$. Aging of both the annealed and cold-worked specimens decreased the diffusivity of hydrogen by about $40 \%$.

It is interesting that Mezzanotte and coworkers (1980) did not observe evidence for trapping of hydrogen in annealed or cold-worked specimens. This observation is unusual in that trapping of hydrogen at micro- or submicrostructural features, e.g., dislocations, is usually expected in metals or alloys. 


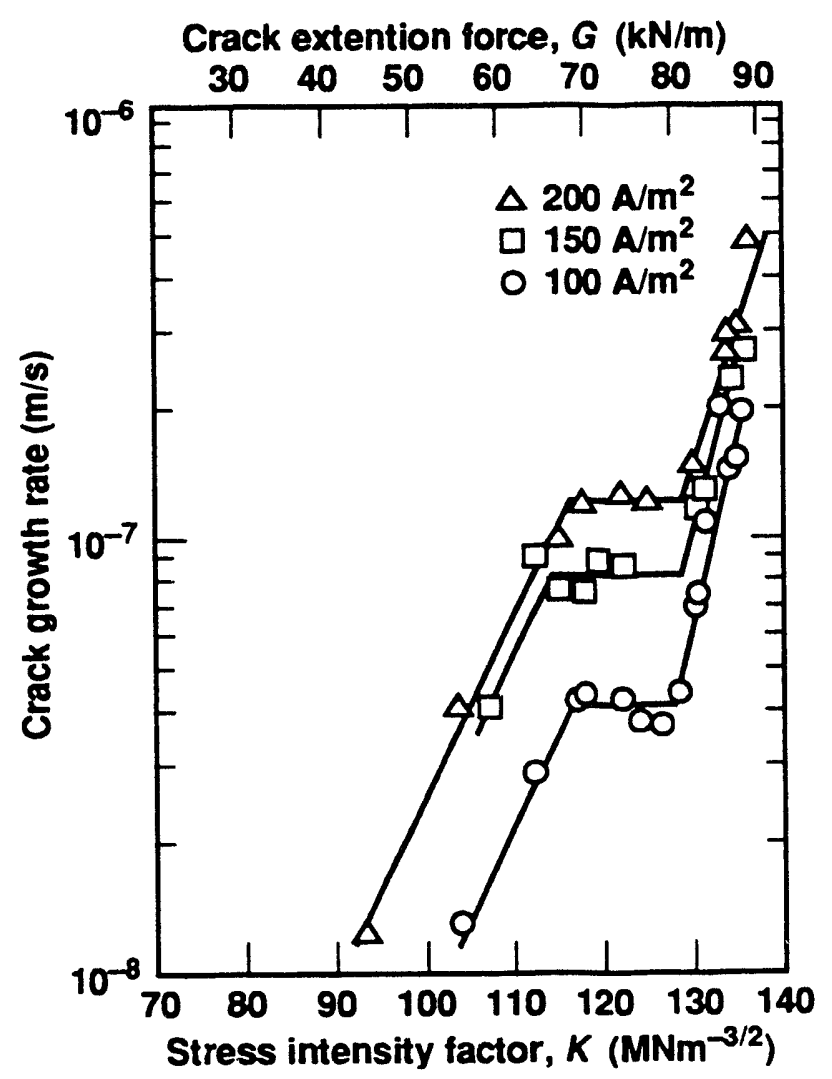

Figure 28. Crack-growth kinetics of aged Alloy C$\mathbf{2 7 6}$ for various charging current densities (Sridhar et al. 1980a). Samples were $50 \%$ cold-worked, aged $100 \mathrm{~h}$ at $500^{\circ} \mathrm{C}$, and hydrogen-charged in $1.8 \mathrm{~N}$ $\mathrm{H}_{2} \mathrm{SO}_{4}+2 \mathrm{~g} /$ / thiourea.

As was discussed above, aging increases the susceptibility of Alloy C-276 to HE. Fiore and Kargol (1981) suggest that this decrease in hydrogen diffusivity is opposite to what is expected if hydrogen lattice diffusion is responsible for HE. The authors also point out that even the diffusivities measured for the unaged specimens are too small to account for the depth of intergranular failure observed in sour-well environments. Therefore, the authors suggest that an accelerated form of hydrogen transport might be responsible for the large crack-growth rates. They suggest the possibility of hydrogen transport under plastic deformation.

Kurkela and Latanision (1979) have shown that the diffusivity of hydrogen in samples of nickel undergoing plastic deformation is about four to five orders of magnitude greater than that of unstressed samples. The hydrogen permeation rate is also strongly dependent on the strain rate, suggesting a dependence on mobile dislocations. To account for accelerated transport under stress, Tien et al. (1976) postulate that the transport of hydrogen could be accelerated by the movement of dislocations, which drag hydrogen with them during plastic deformation.

\subsection{Crack Growth}

Sridhar and coworkers (1980b) used the doubletorsion method to measure crack-growth rates in Alloy C-276 as a function of the stress intensity factor $K$ for various environmental conditions and thermomechanical states. Precracked specimens were cathodically charged with hydrogen at various current densities in a $1.8 \mathrm{~N} \mathrm{H}_{2} \mathrm{SO}_{4}$ solution that contained $2 \mathrm{~g} /$ thiourea as a hydrogen-combination poison.

Figure 28 shows crack-growth rates as a function of charging current for cold-worked plus aged material (Sridhar et al. 1980a). Three-stage crack-growth kinetics were obtained for all samples, and crack growth proceeded by an intergranular fracture mode in each

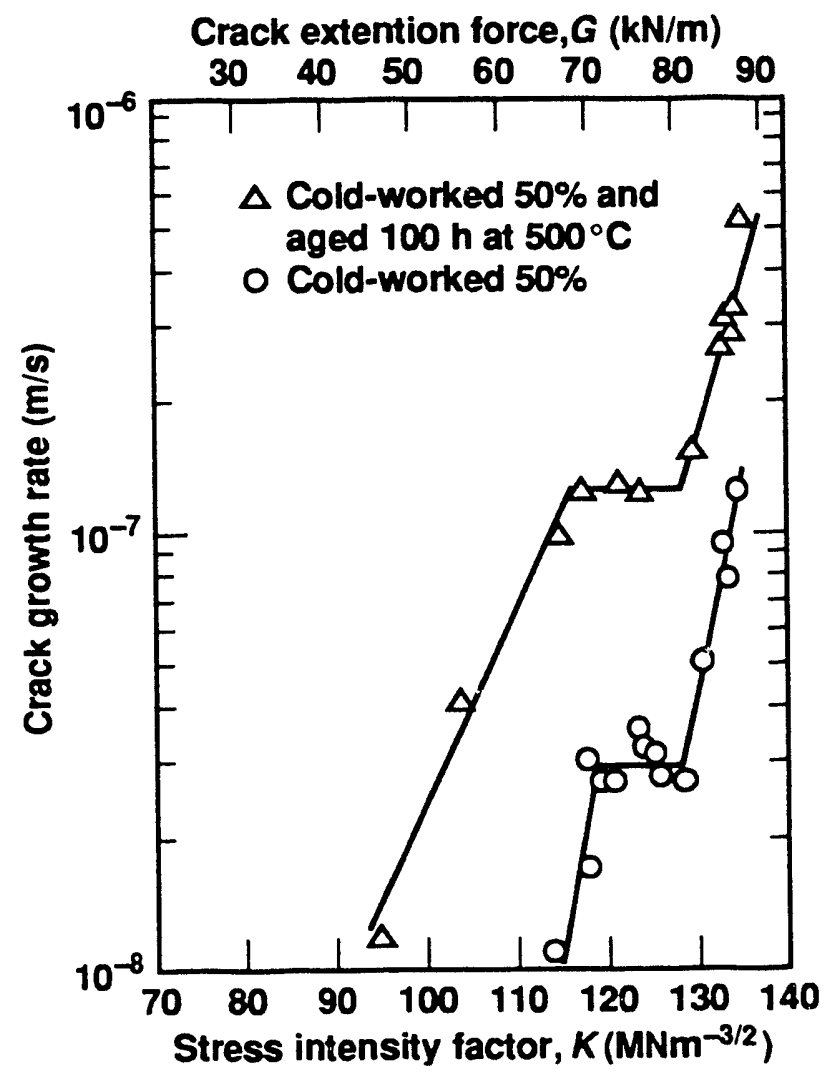

Figure 29. Crack growth kinetics of cold-corked and cold-worked plus aged Alloy C-276 (Sridhar et al. 1980a). Samples were hydrogen-charged in $1.8 \mathrm{~N}$ $\mathrm{H}_{2} \mathrm{SO}_{4}+2 \mathrm{~g} / \mathrm{l}$ thiourea; current density was 200 $\mathbf{A} / \mathbf{m}^{2}$. 
stage. In all three stages, the velocity increased as input hydrogen fugacity increased. In stage II (transportcontrolled) crack growth, the velocity was proportional to the three-fourths power of the hydrogen fugacity.

The crack-growth velocity increased and the quasithreshold stress intensity factor for cracking decreased with aging of cold-worked specimens (see Fig. 29). This result agrees qualitatively with the decrease in TTF observed for aged specimens, as discussed in Sec. 5.5.

Fracture-mechanics (load-decay) studies have indicated that the crack propagation is a stepwise process. Crack extensions of about $70 \mathrm{~mm}$ were determined from the load drops. A calculation showed that these results agree with those predicted from a model of hydrogen-assisted crack growth postulated by Rice (1978). In this model, the crack-growth length is proportional to the distance from the existing crack tip to the region of maximum tensile stress in the crack tip plastic zone. Hydrogen must also concentrate in the plastic region ahead of the crack. Lattice diffusion of hydrogen is not sufficient to account for the crackgrowth rates observed. As discussed in Sec. 5.10, an accelerated form of hydrogen transport is therefore required to explain these results.

\subsection{Summary}

Annealed and uncoupled Ni-Cr-Mo alloys appear to be highly resistant to HE. HE has been found in materials that have been strengthened by cold working and aging, subjected to an aggressive environment, and galvanically coupled to a less noble material. Annealed materials are especially resistant to HE even when they are in aggressive environments and coupled to a less noble material.

In order to induce $\mathrm{HE}$, some means of facilitating hydrogen absorption by the materials are required. Hydrogen charging or coupling to a less noble material have both been shown to induce HE. The liquid medium in contact with the materials must also be aggressive. Several other factors have been shown to increase the susceptibility of the Ni-Cr-Mo alloys to HE. These include:

- Cold working.

- Low-temperature aging $\left(200\right.$ to $\left.700^{\circ} \mathrm{C}\right)$.

- Impurity content.

- Increasing stress level.

- Decreasing service temperature.

\section{Acknowledgment}

Prepared by Yucca Mountain Site Characterization Project (YMP) participants as part of the Civilian Radioactive Waste Management Progran. The YMP is managed by the Yucca Mountain Site Characterization Project Office of the U.S. Department of Energy, Las Vegas, Nevada. The author thanks Bill Clarke, Jack Mitchell, Rich Van Konynenburg, Jay Lepper, and Bill Halsey for reviewing the manuscript. The author also thanks Jay C. Cherniak for his editorial assistance. 


\section{References}

Asphahani, A. I. (1977) "Hydrogen Cracking of Nickel-Base Alloys," Second Intern. Congress on Hydrogen in Metals, Paris, France, 1977, 3C2. NNA.910419.0006.

Asphahani, A. I. (1980a), "Effects of Acids on the Stress Corrosion Cracking of Stainless Materials in Dilute Chloride Solutions," Materials Performance 19(11), 9-14. NNA.890831.0066.

Asphahani, A. I. (1980b), "Corrosion Resistance of High Performance Alloys," Materials Performance 19(12), 33-43. NNA.910419.0028.

Asphahani, A. I. (1980c), "Localized Corrosion of High Performance Alloys," Materials Performance 19(8), 9-21. NNA.890831.0071.

ASTM [American Society for Testing and Materials], ASTM A 262-86, "Standard Practices for Detecting Susceptibility to Intergranular Attack in Austenitic Stainless Steels," Annual Book of ASTM Standards (Amurican Society for Testing and Materials, Philadelphia, Pa.). (Readily available.)

ASTM [American Society for Testing and Materials], Standard G1, "Recommended Practice for Preparing, Cleaning and Evaluating Corrosion Test Specimens," Annual Book of ASTM Standards (American Society for Testing and Materials, Philadelphia, Pa.) (Readily available.)

ASTM [American Society for Testing and Materials], Standard G36, "Standard Practice for Performing SCC Tests in a Boiling Magnesium Chloride Solution," Annual Book of ASTM Standards (American Society for Testing and Materials, Philadelphia, Pa.) (Readily available.)

ASTM [American Society for Testing and Materials], Standard G39, "Practice for Preparation and Use of Bent-Beam Stress-Corrosion Specimens," Annual Book of ASTM Standards (American Society for Testing and Materials, Philadelphia, Pa.) (Readily available.)

ASTM [American Society for Testing and Materials], Standard G50, "Recommended Practice for Conducting Atmospheric Corrosion Tests on Materials," Annual Book of ASTM Standards (American Society for Testing and Materials, Philadelphia, Pa.) (Readily available.)

Baker, E. A. (1988), "Long-Term Corrosion Behavior of Materials in the Marine Atmosphere" in Degradation of Metals in the Atmosphere, S. W. Dean and T. S. Lee, Eds. (American Society for Testing and Materials, Philadelphia, Pa.), ASTM STP 965, pp. 125-144. NNA.910419.0032.

Berkowitz, B. J., and R. D. Kane (1980), "The Effect of Impurity Segregation on the Hydrogen Embritulement of a High Strength Nickel Base Alloy in $\mathrm{H}_{2} \mathrm{~S}$ Environments," Corrosion 36(1), 24-29. NNA.910419.0007.

Bloom, D. S., and N. J. Grant (1954), "An Investigation of the Systems Formed by Chromium, Molybdenum, and Nickel," J. Metals 6, 261-268. NNA.910419.0008.

Bohm, H., K. Ehrlich, and K.-H. Kramer (1970), "Da Ausscheidungsverhalten der Nickellegierung Inconel 625," Metallwissenschaft und Technik 24(2), 139-144. NNA.910419.0009.

Braithwaite, J. W., and M. A. Molecke (1980), "Nuclear Waste Canister Corrosion Studies Pertinent to Geologic Isolation," Nuclear and Chemical Waste Management 1, 37-50. NNA.891215.0024.

Brouillette, C. V. (1958), "Corrosion Rates in Port Hueneme Harbor," Corrosion 14(8), 352t-356t. NNA.910419.0033. 
Brown, M. H. (1969), "The Relationship of Heat Treatment to the Corrosion Resistance of Stainless Alloys," Corrosion 25(10), 438-443. NNA.891009.0032.

Burton, J. J., B. J. Berkowitz, and R. D. Kane (1979), "Surface Segregation in an Engineering Alloy: Hastelloy C-276," Metallurgical Transactions 10A, 677-682. NNA.910419.0010.

Carter, J. P., and S. D. Cramer (1974), "Corrosion Resistance of Some Commercially Available Metals and Alloys to Geothermal Brines," in Corrosion Problems in Energy Conversion and Generation, G. S. Tedmon, Ed. (The Electrochemical Society, Princeton, NJ.), pp. 240-250. NNA.910419.0034.

Carter, J. P., S. D. Cramer, and R. K. Conrad (1980), "An Overview of Materials and Corrosion in Geothermal Systems," in Materials and Corrosion Problems in Energy Systems (National Association of Corrosion Engineers, Houston, Tex.), Paper No. 6. NNA.910419.0036.

Carter, J. P., and F. X. McCawley (March 1978), "In Situ Corrosion Tests in Salton Sea Geothermal Brine Environments," J. Metals, pp. 11-15. NNA.910419.0035.

Christian, J. W. (1965), The Theory of Transformations in Metals and Alloys (Pergamon, Oxford), p. 640. NNA.910711.0044.

Cieslak, M. J., T. J. Headley, and A. D. Romig (1986), "The Welding Metallurgy of Hastelloy Alloys C-4, C-22, and C-276," Metallurgical Transactions 17A, 2035-2047. NNA.910419.0011.

Class, I., H. Grafen, and E. Scheil (1962), "Development of a Corrosion Resistant Ni-Cr-Mo Alloy and Little Harmful Precipitation," Zeitshrift für Metallkunde 53, 283-293. NNA.910419.0012.

Copson, H. R. (1959), "Effect of Composition on Stress Corrosion Cracking of Some Alloys Containing Nickel," Physical Metallurgy of Stress Corrosion Fracture, T. N. Rhodin, Ed. (Interscience Publishers, New York), pp. 247-272. NNA.891128.0595.

Dey, G. K., S. Albert, D. Srivastava, M. Sundararaman, and P. Mukhopadhyay (1989), "Microstructural Studies on Rapidly Solidified Inconel 625," Materials Science and Engineering A199, 175-184. NNA.910419.0059.

[DOE] Department of Energy (1988), Site Characterization Plan, Yucca Mountain Site, Nevada Research and Development Area, Nevada, U.S. Department of Energy, Office of Civilian Radioactive Waste Management, Washington, D.C.

Farmer, J. C., G. E. Gdowski, D. B. Bullen, R. A. Van Konynenburg, R. D. McCright, M. J. Strum, and H. Weiss (1988), Survey of Degradation Modes of Candidate Materials for High-Level Radioactive-Waste Disposal Containers, Lawrence Livermore National Laboratory, Livermore, Calif., UCID-21362. NNA.891222.0305 through NNA.891222.0313

Fink, F. W., and W. K. Boyd (1970), The Corrosion of Metals in Marine Environments, Defense Metals Information Center, Battelle Memorial Institute, Columbus, Ohio, DMIC Report 245 (1970), pp. $23-51$. NNA.890919.0267.

Fiore, N. F., and J. A. Kargol (1981), "Hydrogen-Related Embrittlement of Ni-Base Superalloys," in Hydrogen Effects in Metals, I. M. Berstein and A. W. Thompson, Eds. (The Metallurgical Society of AIME, Warrendale, Pa.), pp. 851-862. NNA.910419.0041.

Fontana, M. G., and N. D. Greene (1978), Corrosion Engineering (McGraw-Hill Book Company, New York), 2nd ed. NNA.891018.0176. 
France, W. D. (1972), "Crevice Corrosion of Metals," in Localized Corrosion-Cause of Metal Failure (American Society for Testing and Materials, Philadelphia, Pa.), ASTM STP 516, pp. 164-200. NNA.891004.0353.

Friend, W. Z. (1980), "Nickel-Chromium-Molybdenum Alloys," in Corrosion of Nickel and Nickel-Base Ailoys (John Wiley \& Sons, New York), pp. 292-367. NNA.890831.0072.

Furuya, T., T. Fukuzuka, K. Fujiwara, and 4 . Tomari (1983), "Gamma-Ray Irradiation Effects on Stress Corrosion Cracking of Alloys for a High Leve: Liquid Waste Package," R-D Kobe Sielosho Gijutsu Hokoku 33(1), 43-46. NNA.890831.0067.

Grafen, H., and G. Bohm (1960), "Die Interkristalline Korrosion von Nickel-Molydan- und Nickel-MolydanChrom-Legierungen," Zeitschrifit für Metallkunde 51(5), 245-252. NNA.910419.0013.

Hack, H. P. (1983), "Crevice Corrosion Behavior of Molybdenum-Containing Stainless Steel in Seawater," Materials Perfarmance 22(6), 24-30. NNA.910419.0037.

Harris, J. ..., and R. C. Scarberry (September 1971), "Effect of Metallurgical Reactions in Inconel NickelChromium-Molybdenum Alloy 625 on Corrusion Resistance in Nitric Acid," J. Metals 45-49. NNA.910419.0014.

Haynes International, Inc. (1987a), "Hastelloy Alloy C-276,", Haynes Product Brochure H-2002B, Haynes International, Inc., Kokomo, Ind. NNA.910627.0003.

Haynes International, Inc. (1987b), "Hastelloy Alloy C-22," Haynes Product Brockure H2019C, Haynes International, Inc., Kokomo, Ind. NNA.910419.0002.

Haynes Intemational, Inc. (1988), "Hastelloy Alloy C-22," Haynes Product Bulletin H-2019C, Haynes Intemational, Inc., Kokomo, Ind. NNA.91u4 1y.u002.

Heubner, U. L., E. Altpeter, M. B. Rockel, and W. Wallis (1989), "Electrochemical Behavior and Its Relation to Composition and Sensitization of NiCrMo in ASTM G-28 Solution," Corrosion 45(3), 249-259.

NNA.910419.0015.

Hibner, E. L. (1986), "Evaluation of Test Procedures for Critical Crevice Temperature Determination for Nickel Alloys in a Ferric Chloride Environment," Paper No. 181, Corrosion/86, Houston, Texas (National Association of Corrosion Engineers, Houston, Tex.). NNA.910821.0002.

Hodge, F. C. 1973), "Effect of Aging on the A nodic Behavior of Ni-Cr-Mo Alloys," Corrosion 29(10), 375-383. NNA.910419.0016.

Hidge, F. G. (1985), "Nickel and High Nickel Alloys," in Corrosion and Corrosion Protection Handbook, P. A. Schweitzer, Ed. (Marcel Dekker, New York), Chapter 3.3. NNA.910419.0003.

Hodge. F. G., and R. W. Kirchner (1976), "An Improved Ni-Cr-Mo Alloy for Corrosion Service," Corrosion 32(8), 332-336. NNA.910419.0017.

Hong, Y. K., and C. H. Pitt (1983), "Corrosion of Selected Metal Alloys in Utah Geothermal Waters," J. Materials for Energy Systems 5(2), 77-83. NNA.890919.0281.

Jackson, R. P., and D. van Rooyen (1972) "Crevice Corrosirr. u. Some Ni-Cr-Mo-Fe Alloys in Laboratory Tests," Localized Corrosion-Cause of Metal Failure (American Society for Testing and Materials, Philadelphia, Pa.), ASTM-STP 516, pp. 210-221. NNA.910419.0029. 
Jena, A. K., S. B. Rajendraprasad, and K. P. Gupta (1989), "The Cr-Mo-Ni (Chromium-Molybdenum-Nickel) System," J. Alloy Phase Diagrams 5(3), 164-177. NNA.910419.0018.

Kane, R. D. (1978), "Accelerated Hydrogen Charging of Nickel and Cobalt Base Alloys," Corrosion 34(12), 442-445. NNA.910419.0042.

Kane, R. D., and B. J. Berkowitz (1980), "Effect of Heat Treatment and Impurities on the Hydrogen Embrittlement of a Nickel Cobalt Base Alloy," Corrosion 36(1), 29-36. NNA.910419.0044.

Kane, R. D., M. Watkins, D. F. Jacobs, and G. L. Hancock (1977), "Factors Influencing the Embrittlement of Cold Worked High Alloy Materials in $\mathrm{H}_{2} \mathrm{~S}$ Environments," Corrosion 33(9), 309-320. NNA.910419.0043.

Kirchner, R. W., and F. G. Hodge (1973), "New Ni-Cr-Mo Alloy Demonstrates High-Temperature Structural Stability with Resultant Increases in Corrosion-Resistance and Mechanical Properties," Werkstoffe und Korrosion 24, 1042-1049. NNA.910627.0002.

Kirchner, R. W., and W. L. Silence (1971), "Corrosion Performance of a Nickel Rich Alloy Evaluated by a Rapid Sensitization Technique," Materials Protection and Performance 10(1), 11-15. NNA.910419.0019.

Kirman, I. and D. H. Warrington (1970), "The Precipitation of Ni3Nb Phases in a Ni-Fe-Cr-Nb Alloy," Metallurgical Transactions 1, 2667-2675. NNA.910711.0046.

Kolts, J., J. B. C. Wu, P. E. Manning, and A. I. Asphahani (1986), "Highly Alloyed Austenitic Materials for Corrosion Services," Corrosion Reviews 6(4), 279-326. NNA.910419.0004.

Kristiansen, H. (1977), "Corrosion of Copper by Water of Various Temperatures and Carbon Dioxide Contents," in Werkstoffe und Korrosion 28, 743-478. NNA.910821.0010.

Kurkela, M., and R. M. Latanision (1979), "The Effect of Plastic Deformation on the Transport of Hydrogen in Nickel," Scripta Metallurgica 13, 927-932. NNA.910419.0045.

Leonard, R. B. (1969), "Thermal Stability of Hastelloy Alloy C-276," Corrosion 25(5), 222-228. NNA.910419.0020.

Lichti, K. A., H. Bijnen, and P. G. Mcllhone (1984), "A Comparison of Pitting Corrosion and Stress Corrosion Cracking Characteristics of Some Engineering Alloys," Metals Australasia (June-July 1984). NNA.89100 i.00113.

Matthews, S. J. (1976), Superalloys, B. H. Kear, D. R. Muzka, and J. K. Tien, Eds., pp. 215-226. (Secondary reference; see Cieslak 1986).

Mezzanotte, D. A., J. A. Kargol, and N. F. Fiore (1980), "Hydrogen Transport in a Ni-Base Superalloy," Scripta Metallurgica 14, 219-223. NNA.910419.0046.

Niederberger, R. B., R. J. Ferrara, and F. A. Plummer (1970), "Corrosion of Nickel Alloys in Quiet and Low Velocity Sea Water." Materials Protection and Performance 9(8), 18-22. NNA.910419.0038.

Pei kner, D., and I. M. Berstein (1977), Handbook of Stainless Steels (McGraw-Hill Book Company, New York), p. 20-8. NNA.891106.0216.

Proetzl, M. (1958), Archiv. f. d. EisenHuttenwesen 29, 745. NNA.910524.0122.

Raghavan, M., B. J. Berkowitz, and J. C. Scanlon (1982), "Electron Microscopic Analysis of Heterogeneous Frecipitaics ini Hastilloy" C 276," Meta!!urgica! Transactions 13A; 979-984. NNA.910419.0022. 
Raghavan, M., R. R. Mueller, G. A. Vaughn, and S. Floreen (1984), "Determination of Isothermal Sections of Nickel Rich Portion of Ni-Cr-Mo System by Analytical Electron Microscopy," Metallurgical Transactions 15A, 783-792. NNA.910419.0021.

Reinhart, F. M. (1969), "Corrosion of Nickel and Nickel Alloys in Deep Ocean Environments," Proc. 24th Conf. National Association of Corrosion Engineers (Nauonal Association of Corrosion Engineers, Houston, Tex.), pp. 713-735. NNA.910419.0039.

Rice, P. W. (1978), "Evaluating Nickel Base and Stainless Alloys for Subsurface $\mathrm{H}_{2} \mathrm{~S}$ Service," Materials Performance 17(9), 16-25. NNA.910419.0047.

Rideout, S., W. D. Manly, E. L. Kamen, B. S. Lement, and P. A. Beck (1951), "Intermediate Phases in Ternary Alloy Systems of Transition Elements," J. Metals 3, 872-876. NNA.910419.0053.

Russel, B., and P. Vela (1963), "Strain Aging of Copper-Tin Alpha Solid Solutions," Philosophy Magazine, 8th Series 8, pp. 677-692. NNA.910419.0048.

Russell, K. C. (1969), "The Role of Excess Vacancies in Precipitation," Scripta Metallurgica 3, 313-316. NNA.910711.0045.

[SAE] Society of Automotive Engineers (1986), Metal and Alloys in the Unified Numbering System (Society of Automotive Engineers, Inc., Warrendale, Pa.), 4th ed., pp. 185-195, 210, 220, 223, and 224. NNA.910419.0005.

Samans, C. H., A. R. Meyer, and G. F. Tisinai (1966), "Sensitization and Thermal Stabilization of Ni-Cr-Mo-Fe-W Alloy," Corrosion 22(12), 336-345. NNA.910419.0023.

Scheil, M. A. (1948), "Stress Corrosion Cracking in Stainless Alloys," in The Corrosion Handbook, H. H. Uhlig, Ed. (John Wiley \& Sons, New York), pp. 174-182. NNA.910419.0030.

Shewmon, P. G. (1963), Diffusion in Solids (McGraw Hill, New York), Chapter 6. NNA.910524.0124.

Shoki, S., and N. Ohnaka (1989), "Effects of Relative Humidity and Chloride Type on Stainless-Steel RoomTemperature Atmospheric Corrosion Cracking," Corrosion Engineering 38, 111-119. NNA.910419.0040.

Sims, C. T. (October 1966), "A Contemporary View of Nickel-Base Superalloys,” J. Metals 1119-1130. NNA.891009.0035.

Southwell, C. R., J. D. Bultman, and A. L. Alexander (1976), "Corrosion of Metals in Tropical EnvironmentsFinal Report of 16-Year Exposures," Materials Performance 15(7), 9-26. NNA.890831.0062.

Sridhar, N., J. A. Kargol, and N. F. Fiore (1980a), "Hydrogen-Induced Crack Growth in a Ni-Base Superalloy," Scripta Metallurgica 14, 225-228. NNA.910419.0049.

Sridhar, N., J. A. Kargol, and N. F. Fiore (1980b), "Effect of Low Temperature Aging on Hydrogen-Induced Crack Growth in a Ni-Base Superalloy," Scripta Metallurgica 14, 1257-1260. NNA.910419.0024, NNA.910419.0050.

Streicher, M. A. (1963), "Relationship of Heat Treatment and Microstructure to Corrosion Resistance in Wrought Ni-Cr-Mo Alloys," Corrosion 19(8), 272t-284t. NNA.910419.0054.

Tawancy, H. M. (1981), "Long-Term Ageing Characteristics of Some Commercial Nickel-Chromium-Molybdenum Alloys," J. Materials Science 16, 2883-2889. NNA.910419.0025. 
Tawancy, H. M., R. B. Herchenroeder, and A. I. Asphahani (June 1983), "High-Performance Ni-Cr-Mo-W Alloys," J. Metals, 37-43. NNA.910419.0026.

Taylor, E. (1970), "Corrosion Resistance of Multiphase Alloys," Materials Protection 9(3), 29-31. NNA.911003.0002.

Tien, J. K., A. W. Thompson, I. M. Berstein, and R. J. Richards (1976), "Hydrogen Transport by Dislocations," Metallurgical Transactions 7A, 821-829. NNA.910419.0051.

Uhlig, H. H. (1971), Corrosion and Corrosion Control: An Introduction to Corrosion Science and Engineering (John Wiley \& Sons, New York), 2nd ed. NNA.891018.0177.

Warren, D. (1960), "Chloride-Bearing Cooling Water and the Stress-Corrosion Cracking of Austenitic Stainless Steel," Proc. Fifteenth Industrial Waste Conference, May 3-5, 1960, Engineering Bulletin of Purdue University, Engineering Extension Series, Series No. 106, pp. 420-438. NNA.891005.0115.

Watkins, M., and J. B. Greer (1976), "Corrosion Testing of Highly Alloyed Materials for Deep, Sour Gas Well Environments," J. Petroleum Technology, June 1976, pp. 698-704. NNA.910419.0052.

Weisert, E. D. (1957), "High Alloys to Combat Corrosion," Corrosion 13(10), 659t-671t. NNA.910419.0027.

Wheatfall, W. L. (1967), "Metal Corrosion in Deep-Ocean Environments," Naval Engineers Journal 79, 611-618. NNA.890919.0280.

Wilde, B. E., and E. Williams (1971), "The Use of Current/Voltage Curves for the Study of Localized Corrosinn and Passivity Breakdown on Stainless Steels in Chloride Media," Electrochimica Acta 16, 1971-1985.

NNA.910419.0031. 
The following number is for Office of Civilian Radioactive Waste Management Records Management purposes only and should not be used when ordering this document:

Accession Number: NNA.910521.0010 

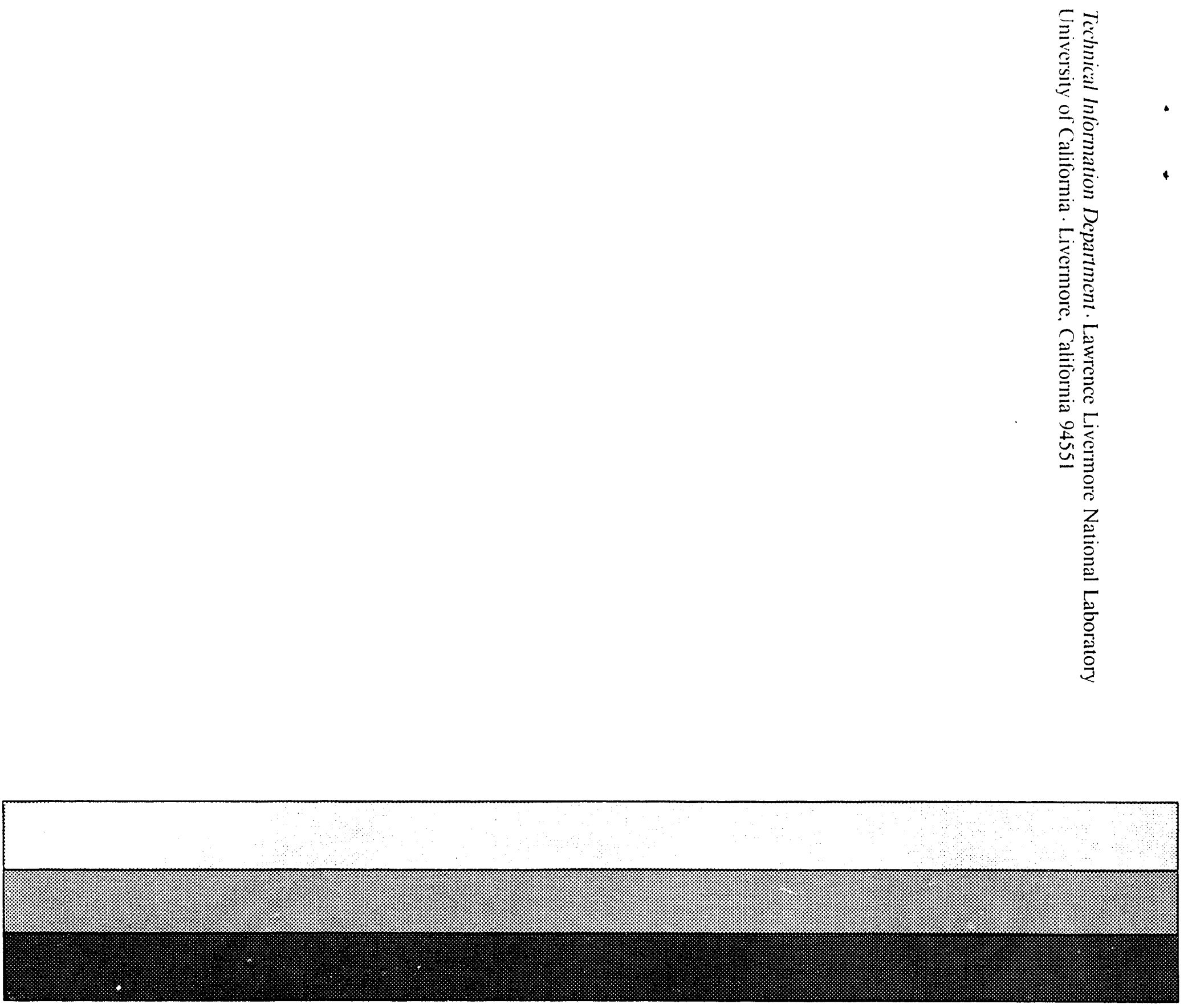

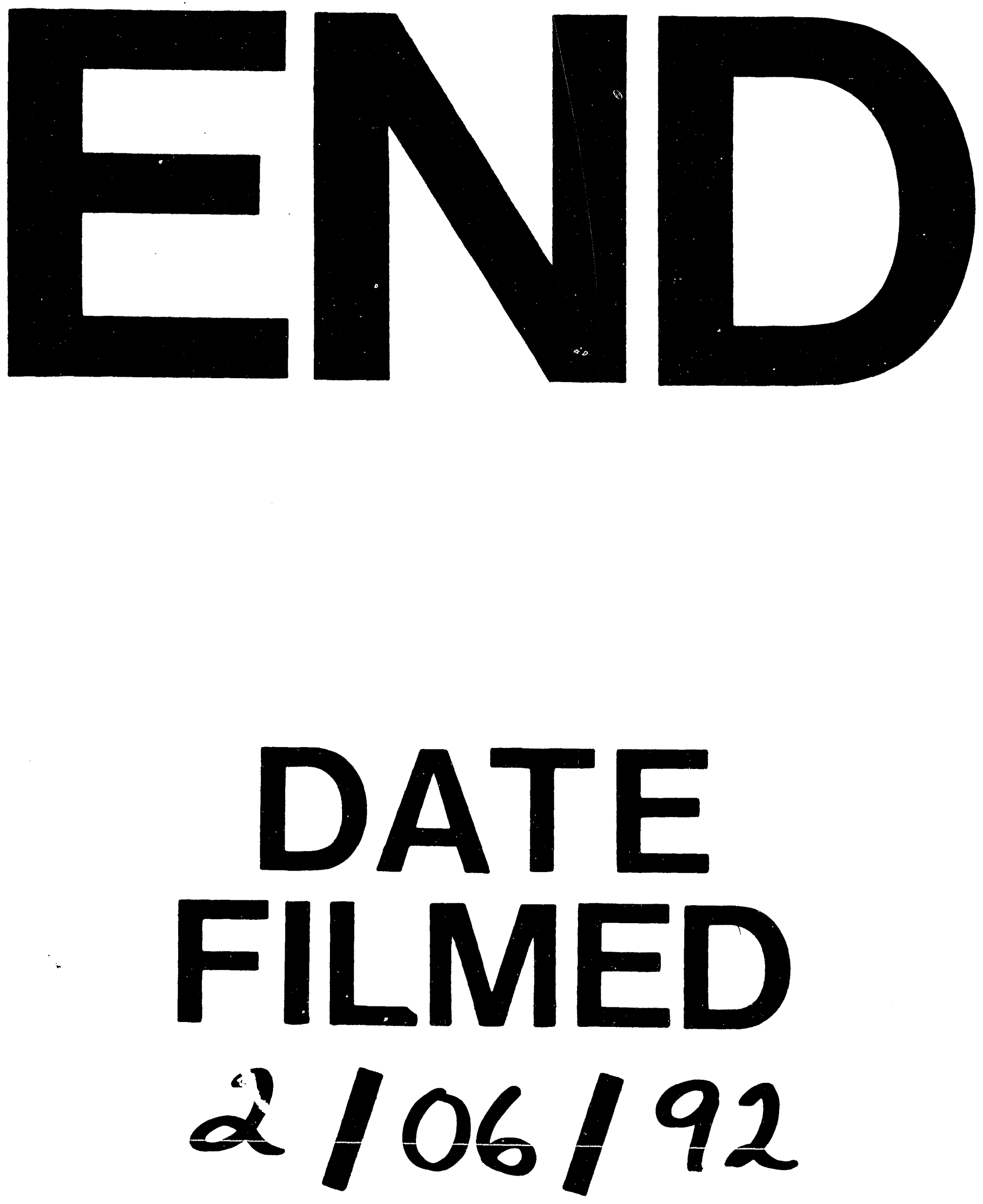


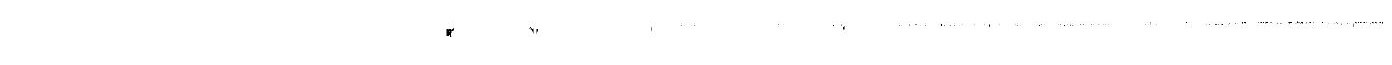

